\title{
ESTUDO DA FORÇA E DA ATIVIDADE ELÉTRICA GERADA PELO MÚSCULO QUADRICEPS FEMORIS SUBMETIDO A EXERCÍCIOS COM RESISTÊNCIA ELÁSTICA.
}

\author{
Dissertação apresentada ao Programa de Pós- \\ Graduação Interunidades em Bioengenharia - \\ Escola de Engenharia de São Carlos/ \\ Faculdade de Medicina de Ribeirão Preto / \\ Instituto de Química de São Carlos da \\ Universidade de São Paulo, para a obtenção do \\ título de Mestre em Bioengenharia.
}

ORIENTADOR: Prof. Dr. NERI ALVES

\section{São Carlos}


Dedico este trabalho aos meus pais Roberto Bernardo de Azevedo e Maria Regina Mícolis de Azevedo e meu avô Humberto Mícolis, pessoas que me deram todas as condições e oportunidades para que eu conseguisse completar esta etapa da minha vida. E a Raquel Napolitano, pessoa cuja presença, apoio e carinho, me inspirou a vencer todos os desafios que permearam a concepção e a realização deste trabalho. Amo vocês! 


\section{AGRADECIMENTOS}

Ao Professor coordenador do Laboratório de Fisioterapia Aplicada ao Movimento Humano (FCT - UNESP) Dr. Rúben de Faria Negrão Filho, que desde o início sempre acreditou e me apoiou na execução deste e de outros trabalhos. Pela amizade, conselhos e orientações.

Ao presidente da CPG do Programa de Pós Graduação Interunidades em Bioengenharia EESC/FMRP/IQSC, Prof. Tit. José Carlos Pereira.

Aos professores do Deparatamento de Fisioterapia da FCT - UNESP, Dr. Augusto Cesinando de Carvalho e Dr. Luis Carlos Marques Vanderlei, por confiarem em meu trabalho, pelas orientações e conselhos.

Ao amigo sempre presente Cristiano Salles Silva, pela ajuda e pelo companheirismo. Valeu!

Aos colegas e amigos de laboratório Diego Basile Colugnati e Leandra Navarro Benatti e Christiano Franklin Tello que tanto colaboraram em vários momentos deste trabalho.

Ao Sr. Ricardo e Sr. Cleisson da empresa Lynx Tecnologia Eletrônica, que deram todo o suporte técnico a instrumentação utilizada no trabalho.

Ao Professor Valdir Silva da Escola SENAI de Presidente Prudente, pelo auxilio na construção do sistema mecânico de exercício utilizado neste trabalho.

A Fundação de Amparo a Pesquisa do Estado de São Paulo (FAPESP) pelo apoio financeiro (Processo $\mathrm{N}^{\mathrm{o}}$ 00/11840-0).

A todos aqueles que de alguma forma contribuíram para a realização deste trabalho. 


\section{AGRADECIMENTOS ESPECIAIS}

Ao meu orientador Professor Dr. Neri Alves, por sempre acreditar em nossas idéias, pelo empenho em melhorá-las; pelos conselhos, sugestões, paciência e amizade. Pelas lições de humildade, como pesquisador, mestre e acima de tudo como ser humano; e principalmente pela disponibilidade em transmitir seus conhecimentos de forma clara e esperançosa. Os meus sinceros agradecimentos.

Ao Professor Dr. Orivaldo Lopes Silva, por ter-me dado o impulso que levou ao desenvolvimento deste trabalho através da Bioengenharia de São Carlos. Seus ensinamentos, orientações e sugestões foram muito importantes para a concepção e execução deste estudo. Obrigado! 
“...N $\mathcal{N}$ unca deve valer como argumento a autoridade de qualquer homem, por excelente e ilustre que seja... É sumamente injusto submeter o próprio sentimento a uma reverência submetida a outros; é digno de mercenários ou escravos e contrário à dignidade humana sujeitar-se a uma opinião devido ao número dos que a têm... É necessário procurar sempre, em compensação, uma razão verdadeira e necessária."

Giordano Bruno 


\section{SUMÁRIO}

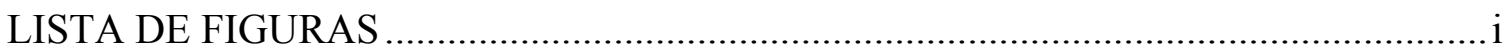

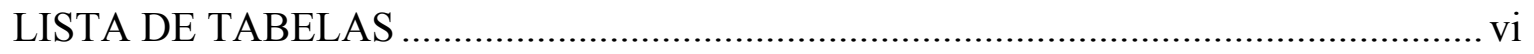

LISTA DE ABREVIATURAS ..................................................................................... vii

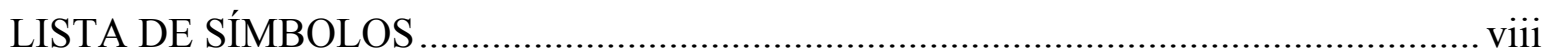

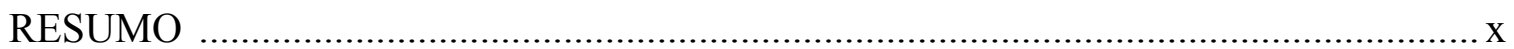

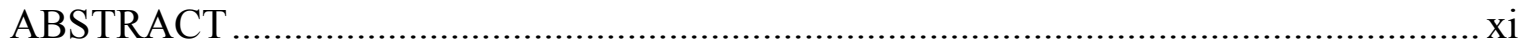

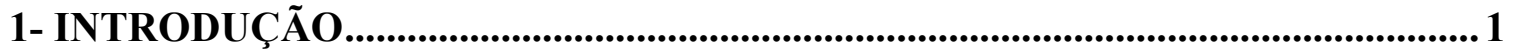

1.1- Bases do exercício físico aplicado à reabilitação .................................................... 2

1.2- A sobrecarga fixa e elástica .......................................................................



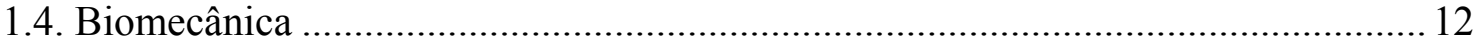

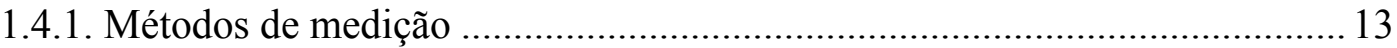

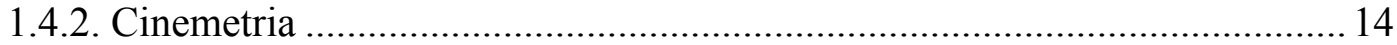

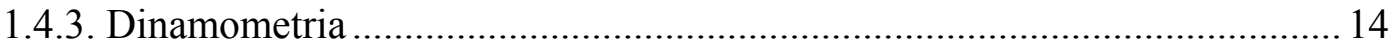

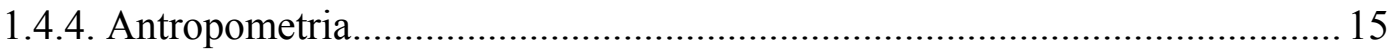

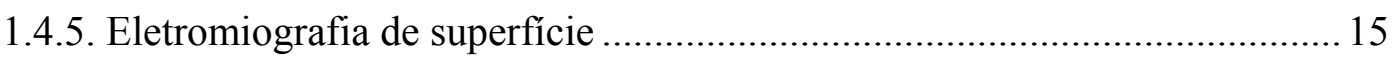

1.4.5.1. Considerações sobre os métodos de analise dos sinais .................. 19

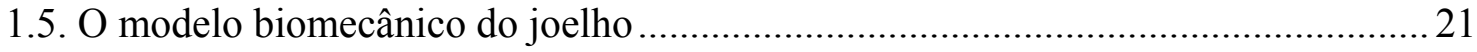

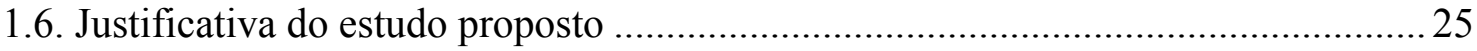

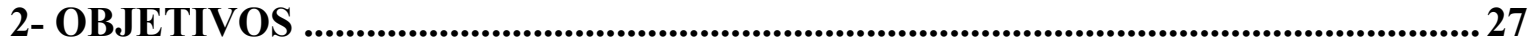

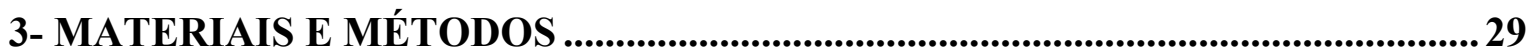

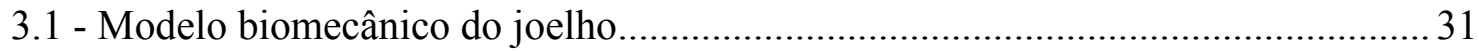

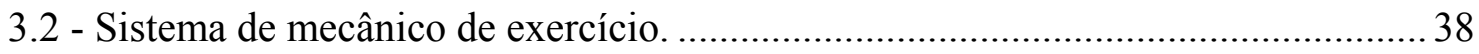

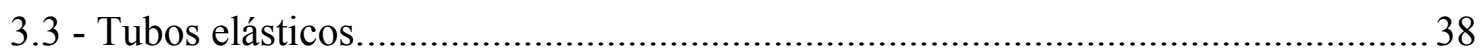

3.3.1 - Equações que descrevem a tensão gerada pelo tubo durante os exercícios no sistema de tração (simulações) 38

3.3.2 - Caracterização mecânica dos tubos elásticos .............................................40

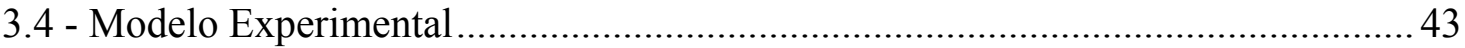

3.4.1 - Modelo Antropométrico e Sujeitos ......................................................... 43

3.4.2 - Aquisição dos dados dinâmicos e cinemáticos......................................... 44 
3.4.3 - Protocolo de exercício para a aquisição dos sinais de EMG.

3.5 - Instrumentação

3.6 - Tratamento dos dados

3.6.1 - Tratamento e aplicação dos dados dinâmicos e cinemáticos

3.6.2 - Tratamento dos sinais EMG

3.6.2.1 - Análise no domínio da freqüência do sinal de EMG.

3.6.2.2 - Análise no domínio do tempo do sinal de EMG 58

4- RESULTADOS 60

4.1 - Força gerada pelo quadríceps femoral em exercícios simulados. 61

4.2 - Força gerada pelo quadríceps femoral em exercício experimental. 65

4.3 - Análise do sinal EMG do músculo reto femoral. 67

4.3.1 - Relação entre a força muscular e padrão de ativação do músculo reto femoral 67

4.3.2 - O processo de fadiga muscular verificado através dos sinais EMG 72

5- DISCUSSÃO. 75

6- CONCLUSÃO 82

7- REFERÊNCIAS BIBLIOGRÁFICAS. 


\section{LISTA DE FIGURAS}

FIGURA 1- Modelo hipotético para: (A) controle da hipertrofia através de treinamento de força e (B) para adaptação em um treinamento de resistência aeróbico

(WEINECK, 1991).

FIGURA 2- Esquema das relações entre o treinamento de força positivo e negativo........ 6

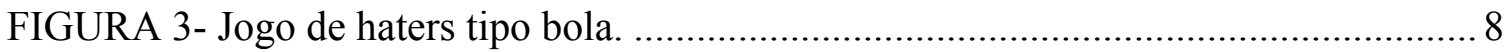

FIGURA 4- Faixas elásticas (A) e tubos elásticos $(\mathrm{B})$ da marca Thera-Band $($, as cores indicam a espessura das faixas e dos tubos.

FIGURA 5- Dinamômetro isocinético e seus acessórios de acoplamento para os diferentes segmentos do corpo humano (A). Sujeito acoplado ao dinamômetro isocinético para realizar exercícios com os músculos da coxa (B) (Biodex Medical Systems ${ }^{\circledR}$, Inc, 2003) ............................................. 11

FIGURA 6- Áreas para análise biomecânica do movimento humano, Baumann (1995)... 13

FIGURA 7- Representação esquemática da geração do potencial de ação da unidade motora. Adaptado de DeLUCA (1979).

FIGURA 8- Representação esquemática da geração do sinal mioelétrico. a) aspecto anatômico. b) modelo fisiológico e instrumentação. Adaptado de DeLUCA (1979).

FIGURA 9- Amplificação diferencial, onde $\mathrm{n}$ representa o ruído do sistema e do ambiente e $\mathrm{m} 1-\mathrm{m} 2$ o SME resultante.

FIGURA 10- Vista sagital das estruturas ósseas que compõe a articulação do joelho: (A) côndilos femorais; (B) platô tibial; (C) Patela. A letra D se refere a cabeça proximal da fíbula, estrutura esta que não participa 
funcionalmente da articulação do joelho (Adapatado de Primal Pictures $\AA$, 2003).

FIGURA 11- Vista frontal do músculo quadríceps femoral: (A) músculo vasto lateral; (B) músculo reto femoral; (C) músculo vasto medial; (D) tendão de inserção do músculo quadríceps na borda superior da patela (Adapatado de Primal Pictures ${ }^{\circledR}, 2003$ ).

FIGURA 12- Orientação das forças de ação dos músculos: VMO - Vasto medial obliquo; VML e VLL-duas porções do músculo vasto intermédio; VLO Vasto lateral; R. F. - reto femoral e T. P. - tendão Patelar.

FIGURA 13- Esquema em corte sagital da articulação do joelho mostrando a alteração do ponto de contato da patela com os côndilos femorais em quatro posições angulares diferentes de flexão (Adaptado de Van Eijden, 1986). 24

FIGURA 14- Forças externas e torque atuante na situação de exercício representada no esquema. Onde $\mathrm{F}_{\mathrm{a}}$ é a tensão gerada pela resistência elástica; $\mathrm{w}$ é o peso da perna; Mk é o torque gerado na articulação do joelho pela força do quadríceps; $\theta$ é o Ângulo de flexão do joelho e $\mathrm{L}_{\mathrm{p}}$ é o comprimento da perna; adaptado de Dvir, 2002

FIGURA 15- . Diagrama de corpo livre demonstrando as forças atuantes no sistema e seus respecticos ângulos de ação; $F_{c}$ - Força de contato articular; $F_{p l}-$ Força do tendão infrapatelar na tuberosidade da tíbia; $\mathrm{w}$ - Peso da perna; $F_{a}$ - Força de aplicação da resistência elástica; $\theta$ - ângulo entre o eixo tíbia e a horizontal; $\alpha$ - Ângulo entre o tendão infrapatelar e o eixo da tíbia; $\mathrm{L}_{\mathrm{p}}$ - Comprimento da perna e $\mathrm{Cm}$ - centro de massa da perna.

FIGURA 16- Esquema mostrando as relações entre a translação do côndilo femoral em relação ao platô tibial e a alteração das distâncias dos braços de força e ângulos durante o movimento de flexão do joelho, onde: $\mathrm{R}_{\mathrm{x}}$ - Distância entre o platô tibial e a tuberosidade da tíbia; $\mathrm{R}_{\mathrm{y}^{-}}$Comprimento da translação do côndilo femoral em ralação a tíbia; R - Distância perpendicular do ponto de contato articular até a ação da força do tendão infrapatelar.

FIGURA 17- Gráfico mostrando a relação entre a força gerada pelo músculo quadríceps e a força resultante na sua inserção na tuberosidade da tíbia em função do ângulo de flexão do joelho; adaptado de Van Eidjin, (1986).

FIGURA 18- Gráfico mostrando a variação do ângulo formado entre o tendão infrapatelar e o eixo da tíbia $(\alpha)$; adaptado de Van Eidjin, (1986). ............ 36

FIGURA 19- Translação do côndilo femoral em relação ao platô tíbia $\left(\mathrm{R}_{\mathrm{y}}\right)$ em função do ângulo de flexão da articulação do joelho( $\theta)$.

FIGURA 20- Montagem do sistema de tração para a realização dos exercícios. 
FIGURA 21- Tubo de látex utilizado para confecção das cordas elásticas utilizadas na situação experimental.

FIGURA 22- Curva de tensão em função da deformação, obtidas através da maquina de ensaios mecânicos (EMIC), para três tubos de látex diferentes.

FIGURA 23- Curva de tensão pela deformação de uma amostra Lengruber 204. O retângulo demarca a região linear, a seta vermelha mostra a tensão máxima de ruptura da amostra e a seta preta mostra um ponto de falha estrutural.

FIGURA 24- Ajuste linear da região delimitada pelo retângulo azul (figura 22), $\mathrm{K}=$ $0,22 \mathrm{~N} / \mathrm{m}$.

FIGURA 25- Voluntário posicionado, realizando o movimento de extensão da perna (vista lateral).

FIGURA 26- Voluntário posicionado, realizando o movimento de extensão da perna (vista anterior).

FIGURA 27- Eletrodo fixado com fita adesiva sobre o músculo reto femoral, o eletrodo de referência foi fixado no maléolo do membro contralateral.

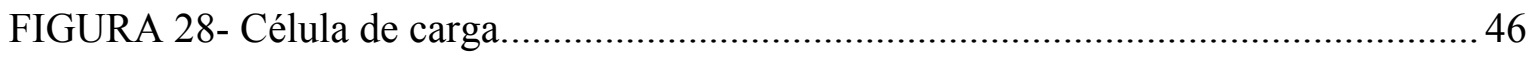

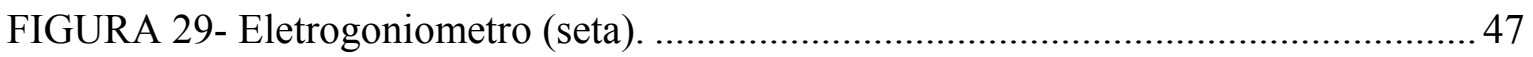

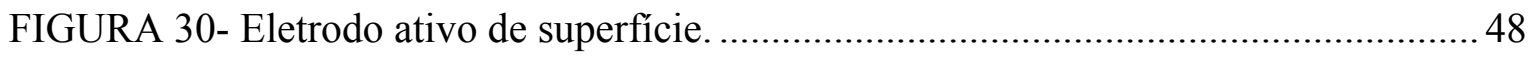

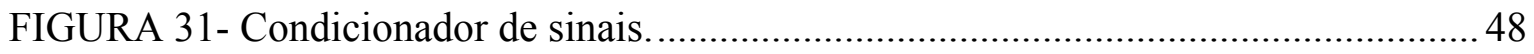

FIGURA 32- Posição angular, média de dez ciclos, da polia do sistema de exercício $(\theta)$ em função do tempo normalizado do ciclo.

FIGURA 33- Velocidade angular, média de dez ciclos, obtida através da derivação da curva da figura 32 .

FIGURA 34- Fluxograma demonstrando a aplicação dos dados para a obtenção dos resultados experimentais e simulados.

FIGURA 35- Exemplo de traçado mioelétrico originado de uma contração múscular isométrica.

FIGURA 36- Exemplo de um sinal mioelétrico originado de varias contrações dinâmicas. No detalhe, observa-se uma região de descontinuidade do sinal.

FIGURA 37- Região vermelha ampliada observa-se o trecho correspondente intervalo entre as contrações (seta). 
FIGURA 38- Exemplo de sequenciamento de 35 traçados mioelétricos, coletados de forma dinâmica, representando o tempo total de exercício.

FIGURA 39- Exemplos de espectros de freqüência de janelas de 1 segundo do sinal mioelétrico apresentado na figura 38 .

FIGURA 40- Exemplo da função de distribuição espectral (SDF) para o espectro de amplitude do sinal $E M G$ onde $F_{1}$ representa a freqüência mediana da janela.

FIGURA 41- Exemplo da seqüência do tratamento do sinal de EMG no domínio do tempo.

FIGURA 42- Força gerada pelo músculo quadríceps para vencer o peso da própria perna, a força aplicada $F_{a}$ isolada e a soma das duas cargas.

FIGURA 43- Força gerada pelo músculo quadríceps para vencer o peso da própria perna, a força aplicada $F_{a}$ isolada e a soma das duas cargas.

FIGURA 44- Força gerada pelo músculo quadríceps quando submetido ao exercício com tubos elásticos que apresentam diferentes fatores de elasticidade $(\gamma \mathrm{A})$.

FIGURA 45- Força gerada pelo músculo quadríceps quando submetido ao exercício com tubos elásticos que apresentam diferentes comprimentos iniciais $\left(\mathrm{L}_{0}\right)$

FIGURA 46- Força média gerada pelo músculo quadríceps femoral e o desvio padrão dos cinco sujeitos submetidos ao exercício com uma resistência elástica (contração excêntrica).

FIGURA 47- Força média gerada pelo músculo quadríceps femoral e o desvio padrão dos cinco sujeitos submetidos ao exercício com uma resistência elástica (contração excêntrica).

FIGURA 48- Sinal EMG do músculo reto femoral durante a execução do exercício com a resistência elástica para os cinco sujeitos $(\mathrm{n}=50)$.

FIGURA 49- Sinal EMG e força do músculo reto femoral durante a execução da contração concêntrica no exercício com a resistência elástica.

FIGURA 50- Sinal EMG e força do músculo reto femoral durante a execução da contração concêntrica no exercício com a resistência elástica.

FIGURA 51- Teste de correlação entre o sinal EMG e a força durante a contração concêntrica no exercício com a resistência elástica. O teste indica uma correlação entre os dados igual a 98\%. 
FIGURA 52- Teste de correlação entre o sinal EMG e a força durante a contração excêntrica no exercício com a resistência elástica. $O$ teste indica uma correlação entre os dados igual a 97\%.

FIGURA 53- Somatório acumulativo do sinal EMG e força do músculo reto femoral durante a execução da contração concêntrica no exercício com a resistência elástica.

FIGURA 54- Somatório acumulativo do sinal EMG e força do músculo reto femoral durante a execução da contração concêntrica no exercício com a resistência elástica.

FIGURA 55- Teste de correlação entre o somatório acumulativo do sinal EMG e a força durante a contração concêntrica no exercício com a resistência elástica. $\mathrm{O}$ teste indica uma correlação entre os dados igual a $99 \%$.

FIGURA 56- Teste de correlação entre o sinal EMG e a força durante a contração excêntrica no exercício com a resistência elástica. $O$ teste indica uma correlação entre os dados igual a 99\%.

FIGURA 57- Comportamento da freqüência mediana durante o tempo total de exercício para os cinco sujeitos submetidos ao experimento.

FIGURA 58- Comportamento da freqüência media durante o tempo total de exercício para os cinco sujeitos submetidos ao experimento. 


\section{LISTA DE TABELAS}

TABELA 1- Características antropométricas dos voluntários submetidos ao exercício.... 44

TABELA 2- Velocidade média executada pelos sujeitos durante os dez ciclos de exercício.

TABELA 3- Tempo de exercício realizado por cada voluntário. 


\section{LISTA DE ABREVIATURAS}

EMG - Eletromiografia.

DEP - Densidade Espectral de Potência.

$F_{\text {med }}-$ Freqüência mediana.

$F_{M}-$ Freqüência Média.

SDF - Função de Distribuição Espectral.

FFT - Transformada Rápida de Fourier. 


\section{LISTA DE SÍMBOLOS}

$\mathrm{L}_{\mathrm{p}}$ - Comprimento da perna.

$\mathrm{F}_{\mathrm{a}}-$ Força aplicada no sistema de exercício.

w - Peso da perna.

Mk - Momento gerado na articulação do joelho.

$\theta$ - Ângulo entre a articulação do joelho e a horizontal.

$\mathrm{F}_{\mathrm{pl}}$ - Força do tendão infrapatelar.

$\mathrm{F}_{\mathrm{c}}-$ Força de compresão no platô tibial.

$\mathrm{Cm}$ - Centro de massa da perna.

$\alpha$ - Ângulo entre o tendão infrapatelar e a tuberosidade da tíbia.

$\gamma$ - Ângulo entre o tendão infrapatelar e o eixo do braço de momento da articulação do joelho.

R - Distância entre o ponto de contato dos côndilos femorais, no platô tibial, e a tuberosidade da tíbia.

$\mathrm{R}_{\mathrm{x}}$ - Distancia entre o platô tibial e a tuberosidade da tíbia.

$\mathrm{R}_{\mathrm{y}}-$ Translação do côndilo femoral sobre o platô tibial.

$\mathrm{F}_{\mathrm{q}}-$ Força do músculo quadríceps.

$\gamma \mathrm{A}-$ Fator de elasticidade. 
$\mathrm{L}_{0}$ - Comprimento inicial da corda elástica.

$\Delta \mathrm{L}$ - Variação do comprimento da corda elástica.

$\mathrm{K}$ - Constante elástica. 


\section{RESUMO}

AZEVEDO, F.M. (2003). Estudo da Força e da Atividade Elétrica Gerada pelo Músculo Quadríceps Femoral Submetido a Exercícios com Resistência Elástica. São Carlos. Defesa (mestrado) - Escola de Engenharia de São Carlos/ Faculdade de Medicina de Ribeirão Preto/ Instituto de Química de São Carlos, Universidade de São Paulo.

A resistência elástica é aplicada amplamente em programas de fortalecimento muscular nos processos de reabilitação física. No entanto, as conseqüências biomecânicas para o músculo exercitado com esta forma de sobrecarga são pouco estudadas. A ausência de fundamentação científica no que tange a aplicação da resistência elástica fez com que surgissem algumas suposições a respeito de sua caracterização biomecânica. Uma delas sugere que o exercício com resistência elástica pode ser caracterizado como sendo isocinético. Neste contexto, o objetivo global deste trabalho foi o de caracterizar o comportamento biomecânico do músculo quadríceps femoral frente ao exercício com resistência elástica. Tal caracterização foi realizada através da utilização de um modelo biomecânico bidimensional da articulação do joelho. O seu comportamento mioelétrico também foi avaliado. Conclui-se de uma forma geral, que o desenvolvimento deste estudo permitiu um entendimento a respeito da interação biomecânica entre o músculo e a resistência elástica durante o exercício. Permitindo dessa forma elucidar algumas questões ligadas a aplicação clínica desta modalidade de exercício.

Palavras chave: Biomecânica, Resistência elástica, Músculo quadríceps femoral. 


\section{ABSTRACT}

AZEVEDO, F.M. (2003) Study of Force and Electromiographic Signal of the Qaudriceps Muscle When Submitted to the Exercises with Elastic Resistance. São Carlos. Msc. Thesis, School of Engineering of São Carlos/ Ribeirão Preto Medical School/ Institute of Chemistry of São Carlos - University of São Paulo.

The elastic resistance is applied in programs of muscular fortification in processes of physical rehabilitation. However, the biomechanicals consequences for the muscle exercised with this resistance form aren't very studied. The low scientific fundamentation for the application of the elastic resistance, results in some suppositions about its biomechanic characterization. One of them suggests that the exercise with elastic resistance can be characterized as isokinetic. In this context, the global objective of this work was characterizing the biomechanic behavior of the quadriceps muscle front to the exercise with elastic resistance. Such characterization was accomplished through the use of a bidimensional biomechanic model of the knee joint. The electromiographic behavior was also evaluated. In a general conclusion, the development of this study allowed an understanding of the biomechanic interaction between the muscle and the elastic resistance during the exercise. Allowing to elucidate some subjects of the clinical application of this exercise modality.

Key words: Biomechanic, quadriceps muscle, elastic resistance 
1. INTRODUÇÃO 


\section{1 - INTRODUÇÃO}

\section{1- Bases do exercício físico aplicado à reabilitação.}

O exercício é compreendido como a repetição sistemática de evoluções de movimentos orientados com o objetivo de aprimorar alguns aspectos como, por exemplo, as propriedades musculares, cardiorrespiratórias ou motoras (KISNER \& COLBY; HOLMANN \& HENTTINGER, 1989; BARBANTI, 1992). Pode ser dividido em passivo, aquele em que não existe a imposição de uma sobrecarga nem a geração de força muscular, e ativo, aquele em que existe a imposição de sobrecarga e geração de força muscular. Os exercícios ativos por sua vez são subdivididos e classificados em três subcategorias conforme o tipo de contração muscular produzida durante a sua execução: isotônicos, isométricos e isocinéticos (KOTTKE \& LEHMANN,1994).

$\mathrm{Na}$ grande maioria dos processos de reabilitação os pacientes comumente são submetidos a alguma modalidade de exercício dependendo das disfunções que apresentam. Quando o objetivo é a hipertrofia muscular, é importante compreender que é necessária a aplicação de exercícios ativos para que ocorra uma resposta fisiológica localizada. A indução destas respostas fisiológicas através dos exercícios ativos, tem por objetivo auxiliar o organismo na recuperação ou manutenção funcional seja do sistema musculoesquelético ou do cardiorrespiratório (POWERS \& HOWLEY, 2000).

Ressalta-se que os métodos de aplicação e a prescrição dos exercícios ativos para um paciente dependem de critérios diretamente ligados ao tipo de disfunção por ele 
apresentada. Por exemplo, em pacientes acometidos por disfunções cardiorrespiratórias os exercícios devem objetivar as respostas fisiológicas sistêmicas no sentido de induzir o condicionamento aeróbico. A forma de sobrecarga utilizada neste tipo de abordagem clínica pode ser representada por caminhadas ou atividades em ergômetros, sendo que a intensidade da sobrecarga é dada pela regulação entre o trabalho e a potência da atividade realizada pelo paciente (KISNER \& COLBY, 1998).

Uma aplicação específica do exercício ativo, é aquela relacionada as disfunções musculoesqueléticas, objeto de estudo desta dissertação. O paciente que apresenta, por exemplo, uma disfunção relacionada a perda de força muscular, deverá ser submetido a exercícios cuja a sobrecarga é imposta especificamente no segmento corporal ao qual o músculo debilitado pertence. Pois neste caso o objetivo é induzir a hipertrofia das fibras musculares através de respostas fisiológicas localizadas (KISNER \& COLBY, 1998; POWERS \& HOWLEY, 2000).

Um programa de exercício eficiente e eficaz deve levar em conta alguns parâmetros gerais e outros específicos. Os gerais são aqueles ligados aos princípios biológicos do treinamento físico e a dosagem do exercício. Os específicos são aqueles ligados ao objetivo do treinamento e a forma de sobrecarga que irá ser utilizada para a sua realização (POWERS \& HOWLEY, 2000).

A utilização dos princípios biológicos do treinamento físico, como base para a elaboração dos protocolos de exercício aplicados aos processos de reabilitação, capacita as pessoas a produzir ou elevar os rendimentos nas diferentes habilidades motoras. Proporcionando assim o aumento da força muscular (hipertrofia muscular), da resistência à fadiga e da potência muscular, conforme processo fisiológico descrito na figura 1. São sete os princípios biológicos do treinamento físico que devem ser respeitados durante o desenvolvimento de um protocolo de treinamento (TUBINO, 1979; BARBANTI, 1986; WEINECK, 1991).

$\left.1^{\circ}\right)$ Princípio da individualidade biológica: o indivíduo deverá ser sempre considerado como a junção do genótipo e fenótipo, dando origem ao somatório de especificidade que o caracteriza. 
$2^{\circ}$ ) Princípio da adaptação: a intensidade adequada de estímulos provoca adaptações no organismo de uma pessoa para torná-la mais apta a realizar uma determinada performance.

$3^{\circ}$ ) Princípio da sobrecarga: as mudanças funcionais no corpo ocorrem somente quando a carga é suficiente para causar uma ativação considerável de energia e mudança plástica nas células relacionadas à síntese de novos tecidos.

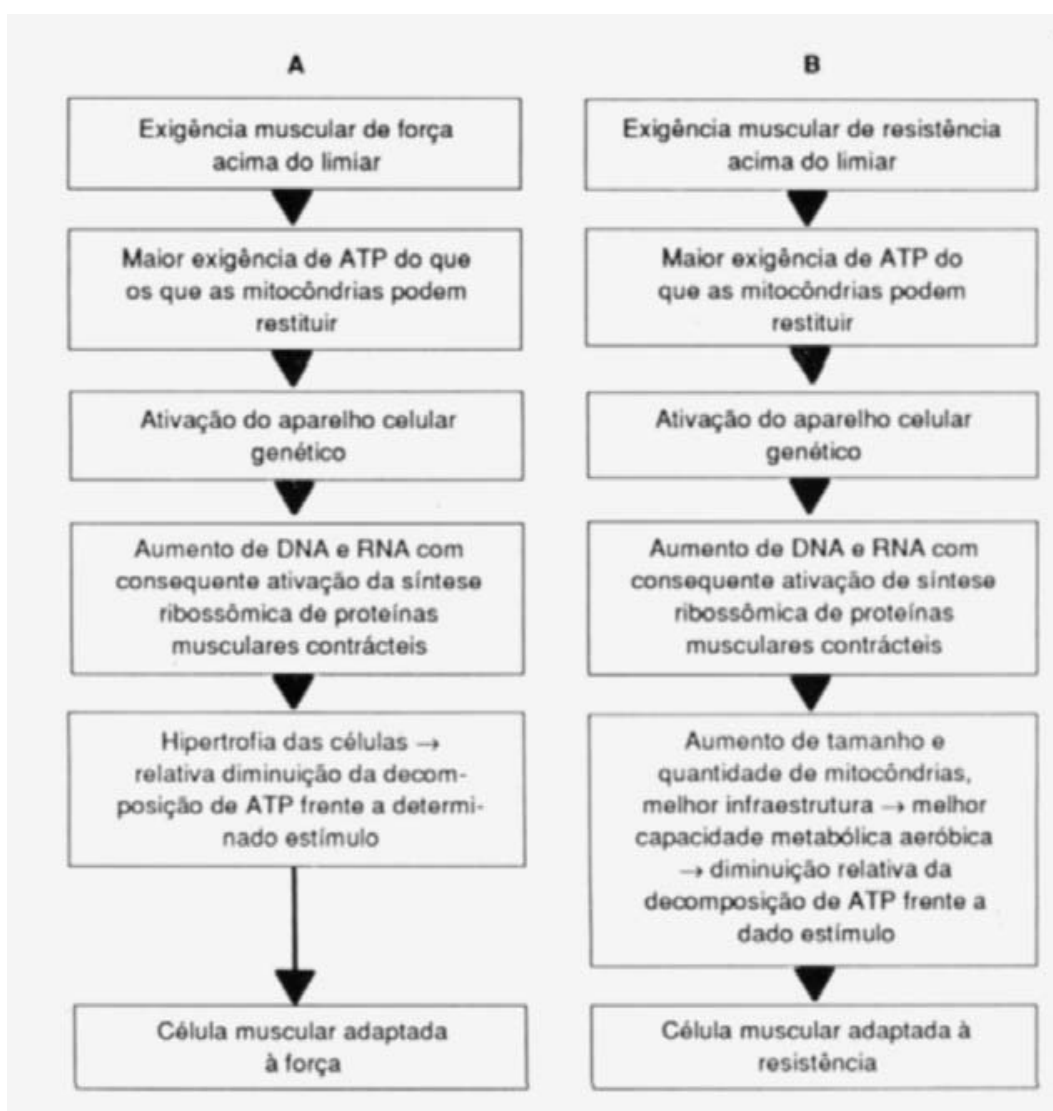

Figura 1. Modelo hipotético para: (A) controle da hipertrofia através de treinamento de força e (B) para adaptação em um treinamento de resistência aeróbico (WEINECK, 1991).

$\left.4^{\circ}\right)$ Princípio da continuidade: Deve haver uma continuidade de trabalho ao longo do tempo, respeitando o período de repouso (máximo de 48 horas) entre os estímulos (aplicação da carga). 
$5^{\circ}$ ) Princípio da interdependência volume-intensidade: a escolha de incidência da sobrecarga na intensidade ou no volume respeitará a qualidade física visada e o período de treinamento.

$6^{\circ}$ ) Princípio da especificidade: o treinamento deve ser montado sobre os requisitos específicos da performance desportiva em termos de segmento corporal utilizado e coordenações psicomotoras utilizadas.

$7^{\circ}$ ) Princípio da reversibilidade: as mudanças corporais conseguidas pelo treinamento físico são de natureza transitória. As mudanças funcionais e morfológicas adquiridas pelo treinamento físico retornam gradativamente aos níveis iniciais após a paralisação do treinamento.

A preocupação sobre a dose adequada de exercício para a obtenção do efeito (resposta fisiológica) desejado é similar a necessidade do médico em conhecer o tipo e a quantidade de uma droga necessária para interagir com uma determinada patologia. A quantidade de exercício imposta a um paciente deve ser dosada de acordo com a disfunção que ele apresenta. É inquestionável, por exemplo, que a dose de atividade física necessária para obter um alto nível de desempenho atlético é diferente da necessária para melhorar um resultado relacionado à manutenção da saúde de um paciente. No entanto, a prescrição adequada do exercício para o paciente, depende de uma avaliação bem elaborada das condições do sistema que será imposto a sobrecarga do exercício. Como exemplo pode-se citar o caso de uma disfunção musculoesquelética onde o objetivo do treinamento seja o ganho de hipertrofia muscular. A base para a prescrição correta da dose de exercício vai depender da avaliação inicial da força que o músculo é capaz de gerar (POWERS \& HOWLEY, 2000).

Dentro da fisioterapia os métodos de avaliação disponíveis para esta situação quase que sempre são subjetivos, como por exemplo, os testes de força sugeridos por Kendall et al. (1995). Os métodos quantitativos diretos ainda são muito pouco utilizados, pelo fato de que as metodologias desenvolvidas em laboratório não serem adequadamente difundidas no meio clínico. 
A escolha da sobrecarga a que o paciente será submetido é a etapa que determinará a resposta fisiológica do sistema musculoesquelético. Como citado anteriormente o enfoque desta dissertação é voltado para a aplicação de métodos de exercícios nas disfunções musculoesqueléticas, mais especificamente naquelas em que ocorre a perda de força muscular. Neste sentido, cabe discutir os meios de sobrecarga mais utilizados, suas formas de aplicação e suas conseqüências fisiológicas para o organismo do paciente (KOTTKE \& LEHMANN, 1994).

A aplicação de programas de exercícios com sobrecarga, para induzir a hipertrofia muscular, é indicada para correção de disfunções ligadas a perda de força. Tais programas têm por objetivo aumentar a quantidade máxima de força que pode ser gerada pelo músculo. Em geral, qualquer músculo regularmente exercitado irá se hipertrofiar. No entanto, pacientes que apresentam seqüelas neurológicas mais graves não respondem de forma satisfatória. (KOTTKE \& LEHMANN, 1994; POWERS \& HOWLEY, 2000).

O treinamento de força dinâmica é subdividido em treinamento de força dinâmica positiva e em treinamento de força dinâmica negativa. Quando tem-se um treinamento de força dominante, teremos uma contração concêntrica que ocasiona a diminuição no comprimento do músculo, gerando força que predomina sobre a sobrecarga imposta ao organismo e acelera o movimento. Já o treinamento de força não dominante produz uma contração excêntrica, provocando o aumento gradual no comprimento do músculo, gerando força que cede à sobrecarga imposta ao organismo e tendo a função de desacelerar o movimento. A figura 2 mostra esquematicamente estas relações.

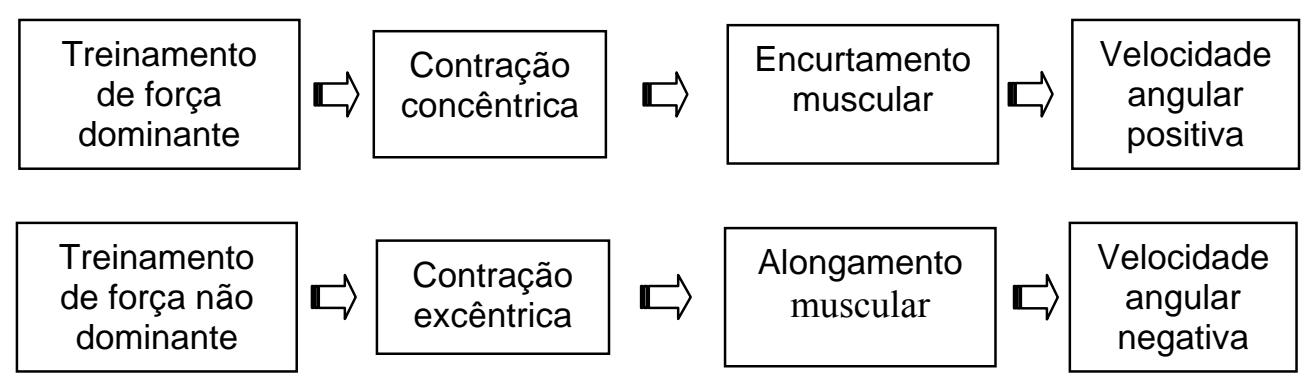

Figura 2. Esquema das relações entre o treinamento de força positivo e negativo. 
Quando se induz uma contração concêntrica e excêntrica num mesmo ciclo de movimento, temos uma forma mista de exercício. No processo de reabilitação é indicada a aplicação de um protocolo que utilize formas mistas de exercício, pois este tem a finalidade de prolongar o tempo em que o músculo é submetido ao estímulo da sobrecarga. Para realizar tal atividade, por exemplo, pode-se utilizar como forma de sobrecarga um halter, também conhecido como peso fixo, acoplado a extremidade distal do segmento a ser exercitado e realizar a flexão e extensão deste segmento, acelerando o movimento durante a fase da contração concêntrica e freando durante a fase excêntrica. Desta forma realiza-se um treinamento dinâmico misto. No entanto, outras ferramentas podem ser utilizadas para desempenhar o papel da sobrecarga no exercício, por exemplo, a corda elástica e o dinamômetro isocinético. É importante salientar que as diferentes formas de sobrecarga citadas vão apresentar interações biomecânicas distintas com o músculo submetido a elas, refletindo diretamente na resposta fisiológica do músculo frente à seqüência de eventos apresentados na figura 1 (AZEVEDO et al., 2002, 2000).

\section{2- A sobrecarga fixa e elástica.}

Como visto anteriormente a escolha da sobrecarga é fundamental dentro do processo de elaboração de um protocolo de exercícios voltado para o fortalecimento muscular. Pois, é a forma que se tem de planejar as interações biomecânicas que vão induzir as respostas fisiológicas desejadas. Dentro do contexto das clínicas de reabilitação nacionais existem dois tipos de sobrecarga comumente utilizados:

a) sobrecarga fixa: conhecida também como peso fixo, pode ser aplicada ao segmento do paciente através de varias formas, por exemplo, haters (figura 3), caneleiras e sacos de areia. Existem várias opções interfaces de interação entre a sobrecarga e o segmento exercitado, podendo-se citar desde as formas mais simples como o simples segurar do peso pela mão, como também formas mais elaboradas representadas pelos equipamentos de ginástica específicos. 


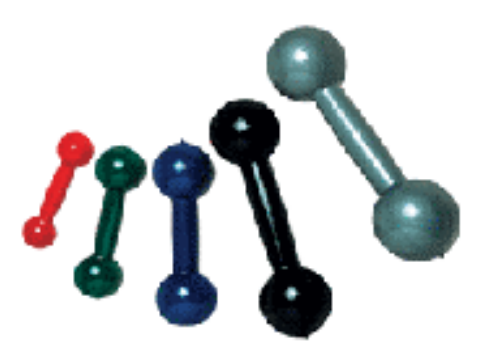

Figura 3. Jogo de haters tipo bola.

b) sobrecarga elástica: conhecida também como resistência elástica, pode ser aplicada ao segmento do paciente através de materiais que apresentem propriedades elásticas bem definidas. Na prática clínica utilizam-se os tubos e faixas elásticas importadas da marca TheraBand ${ }^{\circledR}$ (figura 4) e os tubos de látex nacionais.

È importante deixar claro que os protocolos que utilizam sobrecargas fixas apresentam uma padronização, tanto da interface de aplicação quanto na dosagem da intensidade da sobrecarga bem delineada na literatura científica. Permitindo dessa forma que o terapeuta tenha subsidio para avaliar e reavaliar as respostas de seu paciente frente ao protocolo proposto. Já os protocolos que se baseiam na aplicação da resistência elástica, apesar de serem também amplamente utilizados, não são fundamentadas em relação a interface de aplicação nem a dosagem da resistência. Sendo que os critérios de aplicação de avaliação e de reavaliação ficam a cargo das observações realizadas pelo terapeuta.
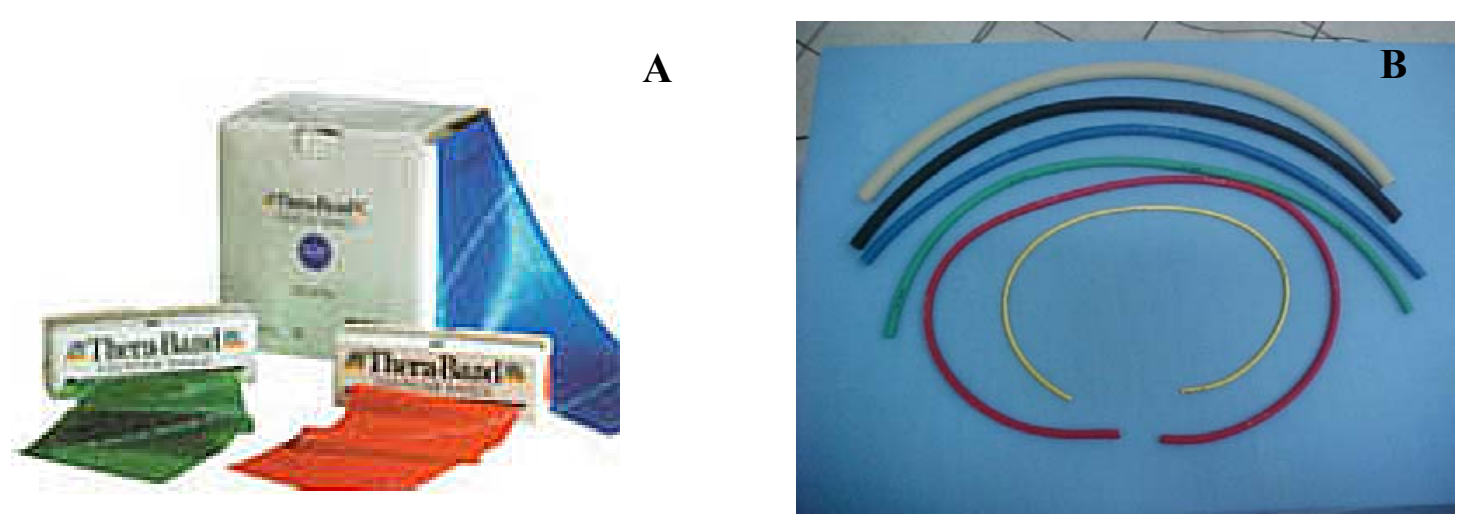

Figura 4. Faixas elásticas (A) e tubos elásticos (B) da marca Thera-Band®, as cores indicam a espessura das faixas e dos tubos. 
No caso de aplicação da resistência elástica, o próprio terapeuta se vê obrigado a adaptar protocolos e métodos de avaliação desenvolvidos para situações em que se utiliza a resistência fixa. Fato que não apresenta fundamentação, pois se sabe que as interações biomecânicas dos músculos com as duas formas de sobrecarga são diferentes, necessitando de abordagens clínicas específicas para cada uma (TELLO, 2002, AZEVEDO, 2002, 2000, 1998; DVIR, 2002).

Outra forma de sobrecarga também utilizada nos protocolos de fortalecimento é a resistência isocinética. No entanto a sua aplicação é mais difundida no exterior pois no Brasil o custo do equipamento é muito elevado, o que faz com que sua aplicação seja restrita a grandes centros de reabilitação.

\section{3- Conceitos de isocinética.}

O termo isocinético pode ser encontrado na literatura científica como sendo ou um tipo de contração muscular, ou uma modalidade de exercício, ou uma forma de sobrecarga. Então a que situação o termo isocinético se refere exatamente?

A palavra isocinético tem origem no grego, isos significa igual e kinetos significa movimento.Tal palavra refere-se usualmente a movimento com velocidade constante. Este movimento produz contrações musculares específicas em resposta a uma sobrecarga adequadamente aplicada ao membro exercitado. Portanto, pode existir o exercício e a contração isocinética e, também, a sobrecarga que produz o exercício e a contração isocinética. Todos estes termos referem-se ao mesmo principio desenvolvido por James Perrine em 1967 (Dvir , 2002).

Perrine (1978) desenvolveu a teoria do exercício isocinético baseando-se em duas relações musculares que já haviam sido bem determinadas na época (DVIR, 2002):

(a) a relação entre o comprimento muscular e a magnitude da tensão correspondente;

(b) a relação entre momento e velocidade angular em contrações dinâmicas. 
Se a relação entre força e comprimento é considerada como um parâmetro fisiológico básico do músculo esquelético, um outro parâmetro básico é a relação entre força, ou tensão desenvolvida pelo músculo e a sua velocidade ou rapidez de contração. Dessa forma performance muscular dinâmica pode ser medida (DVIR, 2002):

(a) controlando a carga externa e medindo e/ou calculando as velocidades resultantes e acelerações; ou

(b) controlando a velocidade e medindo a produção de força.

O segundo enfoque, para o qual os dinamômetros isocinéticos são particularmente adequados, tem sido adotado para a quantificação da performance muscular desde o final da década de 60 (PERRIN, 1993; DVIR, 2002).

Uma formula que descreve a relação entre a geração de força muscular e velocidade de contração foi proposta por Hill (1953). Essa equação pode ser apresentada em forma normalizada:

$$
V=(1-F) \cdot\left(1+\frac{F}{k}\right)
$$

onde:

$V=\frac{v}{v_{\text {máx }}} ; \mathbf{v}$ é a velocidade de contração e $\mathbf{v}_{\text {máx }}$ é a veocidae máxima de contração sem carga;

$F=\frac{f}{f_{\text {máx }}} ; \mathbf{f}$ é a força muscular gerada durante a contração e $\mathbf{f}_{\text {máx }}$ é a força isométrica máxima gerada pelo músculo;

k ; é uma constante relacionada a parâmetros biomecânicos do músculo. 
Portanto um dos princípios básicos da isocinética é que o nível de força muscular gerado durante a contração, a uma velocidade predeterminada, será a máxima possível. A aplicação efetiva desse tipo de exercício só foi possível com o advento dos computadores e dispositivos eletrônicos, que fazem a leitura de informações como momento de força e velocidade angular e limitam a velocidade do movimento a um valor preestabelecido variando a resistência imposta ao membro exercitado. Podemos dizer então que o dinamômetro isocinético (Figura 5) é um equipamento limitador de velocidade, que por sua vez apresenta reflexos na dinâmica do músculo exercitado.

A entrada do dinamômetro isocinético no mercado fez com que a comunidade cientifica envolvida no campo da reabilitação desenvolvessem estudos relativos a aplicação e a eficiência deste tipo de exercício no processo de reabilitação do paciente, mais especificamente nos protocolos de fortalecimento muscular.
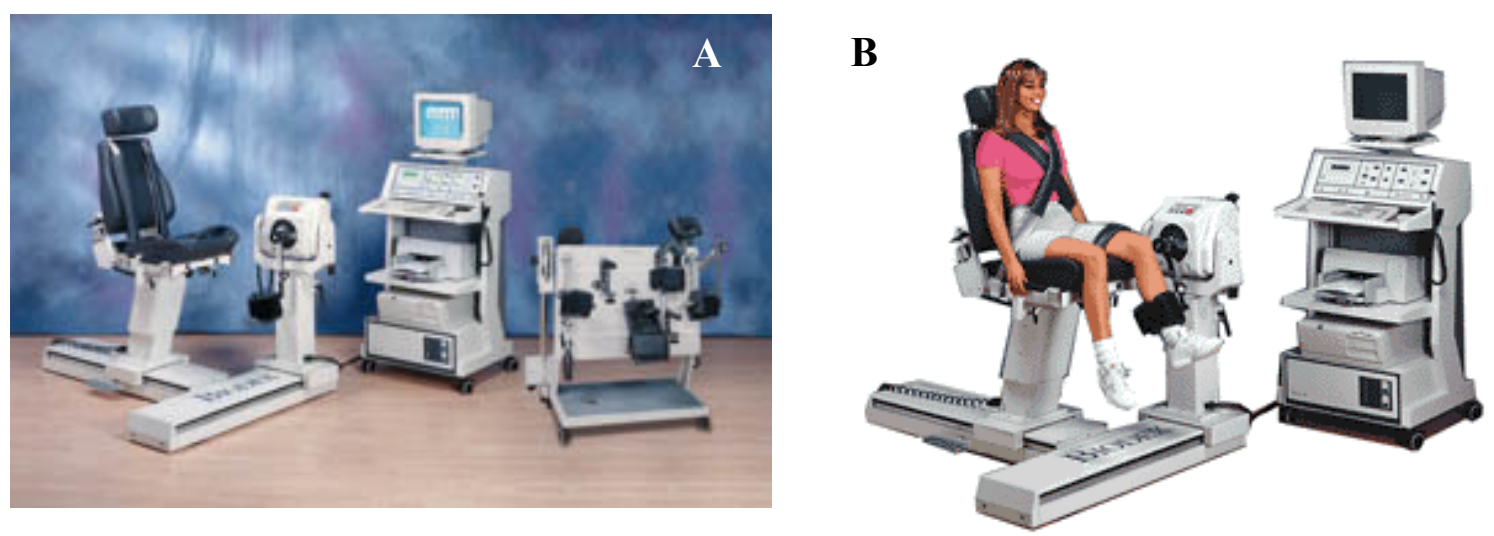

Figura 5. Dinamômetro isocinético e seus acessórios de acoplamento para os diferentes segmentos do corpo humano (A). Sujeito acoplado ao dinamômetro isocinético para realizar exercícios com os músculos da coxa (B) (Biodex Medical Systems ${ }^{\circledR}$, Inc, 2003).

Até os dias atuais vários trabalhos relacionados ao dinamômetro e ao exercício isocinético ainda são realizados. Na sua maioria, estes trabalhos demonstram que o exercício isocinético é uma ótima opção para o treinamento muscular de pacientes em fase de reabilitação. A principal vantagem é fazer com que o paciente atinja o grau de força, desejado, em um menor tempo de treinamento (FARINA et al., 1999; CESARELLI et al.; 1999; LUH et al., 1999). 
Em síntese: no exercício em um dinamômetro isocinético programa-se uma velocidade de movimento desejada e solicita-se ao indivíduo que aplique a força máxima que o mesmo é capaz. $\mathrm{O}$ equipamento ajusta a resistência mecânica imposta ao membro para que este desenvolva a velocidade programada, de forma constante. Lembrando que a potência muscular pode ser calculado pelo produto da força do músculo pela velocidade de contração, e que nesta situação a força é máxima, tem-se que, no exercício isocinético o músculo desenvolve sua máxima potência em toda a amplitude do movimento. Portanto, a característica mais importante do exercício isocinético é que o músculo exercita a potência máxima possível, para a velocidade programada, e não o fato de ser a velocidade constante. Evidente que este arranjo depende da cooperação do individuo, que deve se esforçar para realmente exercer a força máxima em todo o arco do movimento. Outro aspecto que comparece é que havendo uma patologia dificultando a ação muscular em um determinado ângulo, o equipamento ajusta o torque resistivo para não permitir a variação de velocidade. Assim o dinamômetro isocinético pode ser caracterizado não apenas como uma ferramenta de exercício para treinamento e reabilitação física, mas também como ferramenta de diagnóstico funcional e de acompanhamento da evolução do processo de reabilitação. Que pode ser feito através do registro dos torques gerados pelo indivíduo em diferentes momentos do tratamento.

\section{4- Biomecânica.}

Segundo Amadio (1996), a biomecânica pode ser conceituada como uma ciência que trata de análises físico-matemáticas de sistemas biológicos e como conseqüência, também de movimentos humanos.

Um dos objetos de estudo da biomecânica são as forças internas do corpo humano. Segundo Amadio (2000) nesta abordagem a biomecânica investiga as forças que têm sua origem dentro do corpo e na maioria dos casos pressupõe o conhecimento de medidas externas obtidas através dos métodos de medição descritos por Baumann (1995). A força que um músculo gera no seu ponto de inserção durante uma contração, 
as forças de compressão articular e as forças ligamentares são exemplos de forças internas.

A medida direta das forças internas é um processo inviável principalmente devido as questões éticas em relação a procedimentos invasivos e de experimentação com seres humanos, que seriam inerentes a este tipo de abordagem. No entanto estas forças podem ser calculadas por intermédio de parâmetros da cinemática e dinâmica do movimento, bem como das características mecânicas do aparelho locomotor e de suas estruturas funcionais. A biomecânica interna preocupa-se com a determinação dessas forças e suas conseqüências resultantes sobre as estruturas biológicas envolvidas (AMADIO, 1996).

A biomecânica externa refere-se as características observáveis exteriormente ao corpo estudado, como por exemplo o seu deslocamento no espaço e as forças aplicadas externamente.

\subsection{1- Métodos de medição.}

Os métodos de avaliação utilizados pela biomecânica para abordar as diversas formas de movimento são: antropometria, cinemetria, dinamometria, e eletromiografia ,figura 6 (BAUMANN, 1995).

Utilizando-se destes métodos o movimento pode ser descrito e modelado matematicamente, permitindo uma melhor compreensão dos mecanismos internos reguladores e executores do movimento do corpo humano.

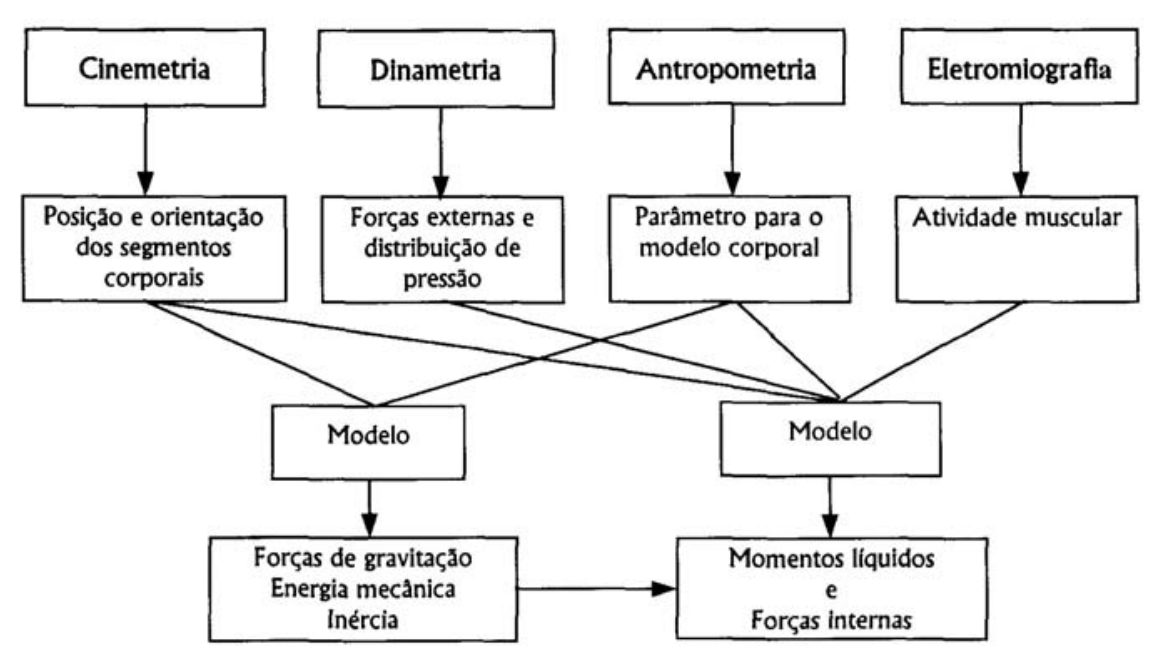

Figura 6. Áreas para análise biomecânica do movimento humano, Baumann (1995). 


\subsection{2- Cinemetria.}

A cinemetria é o nome dado ao estudo do posicionamento dos segmentos corporais em função do tempo em diferentes tipos de movimento. Portanto, para a cinemetria é importante os parâmetros cinemáticos do movimento: posição, orientação espacial (sistema de coordenadas), velocidade e aceleração de cada segmento.

Para os estudos de cinemetria existem diversos equipamentos, técnicas e sensores. Destaque especial tem sido dado aos equipamentos de vídeo para registro de imagem usando luz visível ou infravermelho. As imagens capturadas são submetidas a diversas formas de tratamento com diversos graus de complexidade dimensional. Também se faz o uso de rotinas específicas para calcular variáveis cinéticas através da reconstrução de coordenadas dos pontos anatômicos de interesse. No entanto, dependendo do estudo proposto como, por exemplo, o movimento de um membro no plano, é suficiente o registro da variação da posição angular em função do tempo. Neste caso o uso do eletrogoniometro é adequado.

\subsection{3- Dinamometria.}

A dinamometria engloba todos os tipos de medidas de força e ainda distribuição de pressão através das quais pode-se interpretar as respostas de comportamento dinâmico do movimento humano (AMADIO, 1996).A dinamometria, como o próprio nome diz, se ocupa das variáveis dinâmicas através de transdutores de força, englobando todos os tipos de força e pressão acessíveis externamente. Ela se preocupa em medir tanto as forças externas de reação do solo como as forças dos membros que é de particular interesse nas atividades motoras estáticas ou dinâmicas que envolvam alguma forma de apoio. A definição do conceito de força, sob o aspecto físico, somente pode ser interpretada a partir do efeito de sua ação, e assim, interpreta-se seus efeitos estático e dinâmico (AMADIO, 1996). Para isso utiliza-se a plataforma de força, as células de carga de vários tipos e também os sistemas de baropodometria (AMADIO 1996, 2000). 


\subsection{4- Antropometria.}

As grandezas derivadas da anatomia humana são objeto de estudo da antropometria. Ela determina os parâmetros geométricos e inerciais do corpo humano e também fornece a segmentação da estrutura do corpo humano adequadamente dividido para a análise matemática, determinando:

(a) a forma geométrica, as posições das articulações e a posição do centro de massa de cada segmento corporal, bem como os pontos de origem e inserção dos músculos para determinação das linhas de ação das forças musculares e braços de alavanca;

(b) os parâmetros inerciais: massa de cada segmento, momento de inércia e raio de giro.

As variáveis antropométricas fundamentais (massa, centro de massa e momento de inércia dos segmentos, bem como a localização dos pontos de ação das forças) podem ser obtidas através de procedimentos teóricos (VECCHIA, 1998).

Neste trabalho utilizou-se os quatro métodos descritos acima: i) dinamometria, para quantificar a intensidade das forças que agem externamente ao segmento exercitado; ii) cinemetria, para obter o posicionamento angular do segmento durante o exercício; iii) eletromiografia (EMG), para avaliar o comportamento elétrico do músculo exercitado; iv) modelo antropométrico, para a obtenção do centro de massa, peso e comprimento do segmento corporal estudado.

\subsection{5-. Eletromiografia de superfície.}

Eletromiografia é o termo genérico que expressa o método de registro da atividade elétrica de um músculo quando realiza contração. Ela apresenta inúmeras aplicações, notadamente na clínica médica para diagnóstico de doenças neuromusculares; na reabilitação, na reeducação da ação muscular (biofeedback eletromiografico); na anatomia, com o intuito de revelar a ação muscular em determinados movimentos; e na biomecânica na sentido de servir como ferramenta indicadora de alguns fenômenos (AMADIO 1996). 
$\mathrm{Na}$ biomecânica, a utilização da eletromiografia tem como propósitos fundamentais: (a) servir como indicador de estresse muscular; (b) ser um identificador de padrões de movimentos e (c) identificar parâmetros de controle do sistema nervoso. No contexto deste trabalho utiliza-se a eletromiografia como parâmetro biomecânico para indicar os processos relacionados ao controle do sistema nervoso (padrão de ativação muscular) e a fadiga do músculo analisado (AMADIO, 1996).

Este tópico merece uma atenção especial, pois se trata de uma ferramenta que ainda apresenta metodologias de aplicação e principalmente de tratamento muito controversas (MOHAMED et al., 2002; ONISHI et al., 1999; MORITANI, 1978; BROWN \& STEIN, 1974; LIPPOLD, 1952; LAWRENCE \& DeLUCA, 1983). È importante dizer que a EMG é um indicativo indireto que reflete os acontecimentos fisiológicos do músculo, acontecimentos estes que são extremamente individualizados (PERREIRA \& AZEVEDO, 2002; ALMEIDA, 1997).

Sob condições normais, um potencial de ação que se propaga por um motoneurônio ativa todos os seus ramos; por sua vez, estes ativam todas as fibras musculares de uma unidade motora (KRNJEVIC, 1958; PATON, 1967). Quando a membrana pós-sináptica de uma fibra muscular for despolarizada, a despolarização propaga em ambas as direções ao longo da fibra. A despolarização de membrana, acompanhada por um movimento de íons, gera um campo eletromagnético na redondeza das fibras musculares. Um eletrodo localizado neste campo irá detectar o potencial cuja variação no tempo é conhecida como um potencial de ação. Uma representação esquemática desta situação é apresentada na figura 7. No diagrama, $\boldsymbol{n}$ representa o número total de fibras musculares de uma unidade motora que está suficientemente perto do eletrodo para os potenciais de ação serem descobertos por ele. Para simplificar, são descritas apenas as fibras musculares de uma unidade motora. Os potenciais de ação associados com cada fibra muscular são apresentados do lado direito. Os potenciais individuais de ação de cada fibra muscular representam a contribuição que cada fibra muscular ativa faz ao sinal detectado no local do eletrodo (DeLUCA, 1979).

Por razões técnicas, o eletrodo captador é tipicamente bipolar e o sinal é amplificado diferencialmente. A forma do potencial de ação observado dependerá da orientação dos contatos do eletrodo gravador com relação às fibras ativas. Para simplificar, na figura 7 os contatos do eletrodo estão alinhados em paralelo com as fibras musculares. Com este arranjo, os potenciais de ação observados, gerados nas 
fibras musculares, terão uma forma bifásica e o sinal das fases dependerá da direção de despolarização da membrana da célula muscular (GEDES, 1972).

As formas e o espectro de freqüência dos potenciais de ação serão afetados pelo tecido entre a fibra muscular e o local do eletrodo. A presença deste tecido cria um efeito de filtro passa-baixa diminuindo a largura de banda com o aumento de sua espessura (LINDSTRON, 1970). Este "efeito filtro" do tecido é muito mais pronunciado para as captações de sinais usando eletrodos de superfície que para as captações usando eletrodos invasivos porque estes ficam situados mais próximos às fibras musculares ativas.

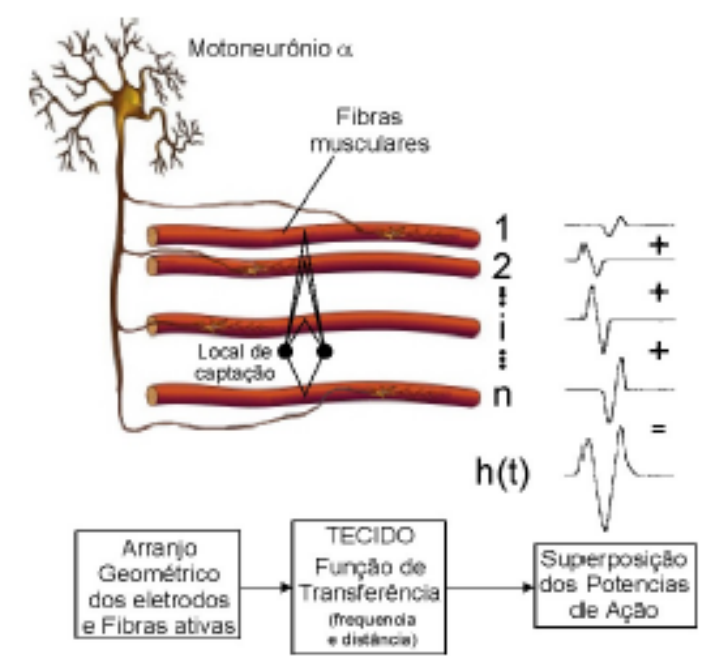

Figura 7. Representação esquemática da geração do potencial de ação da unidade motora. Adaptado de DeLUCA (1979).

A despolarização da fibra muscular de uma unidade motora se sobrepõe no tempo e o sinal resultante presente no local da captação constitui-se numa superposição espaço-temporal das contribuições dos potenciais de ação individuais. Para manter o músculo contraído, o sistema nervoso enviará uma seqüência destes potenciais, para que as unidades motoras sejam repetitivamente ativadas, resultando em um trem de pulsos. O sinal mioelétrico (EMG) será resultante da somatória destes trens, pois várias unidades motoras são acionadas para a manutenção e ativação da contração muscular (figura 8). 
Eletrodos invasivos (de fio ou agulha) são capazes de detectar o potencial de ação de uma única unidade motora, apresentam maiores amplitudes e espectro de potência mais amplo com freqüências até $10 \mathrm{kHz}$ (WEBSTER, 1998). No entanto, estes eletrodos apresentam vários inconvenientes como a necessidade de excelente esterilização, o perigo da quebra dos fíos dentro do músculo e, sobretudo o desconforto do paciente. Para evitar estes inconvenientes, na biomecânica experimental são utilizados eletrodos não invasivos (de superfície). Com a utilização destes eletrodos, o sinal de EMG captado apresenta freqüências até cerca de $500 \mathrm{~Hz}$ e amplitudes variando entre $5 \mu \mathrm{V}$ e $50 \mu \mathrm{V}$ dependendo do músculo analisado e configuração do eletrodo utilizado (ALMEIDA, 1997).

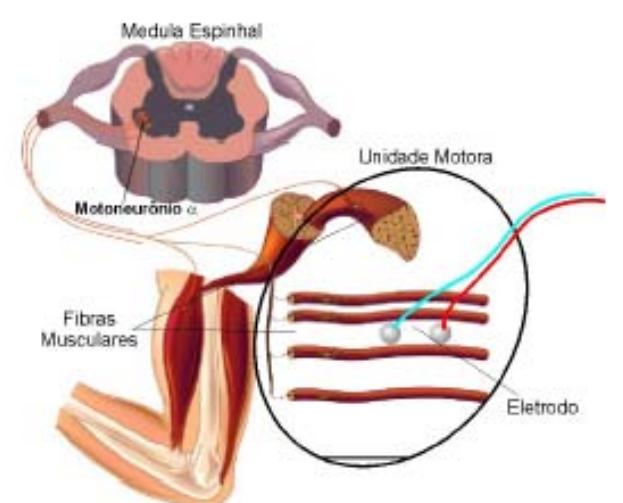

a)

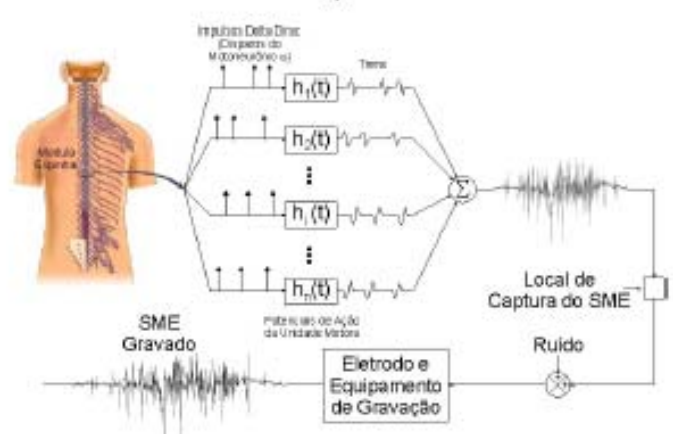

b)

Figura 8. Representação esquemática da geração do sinal mioelétrico. a) aspecto anatômico. b) modelo fisiológico e instrumentação. Adaptado de DeLUCA (1979).

Para minimizar o ruído do sinal, que é composto por baixas amplitudes, é recomendado que se utilize eletrodos chamados de eletrodos ativos, estes são 
confeccionados com um amplificador diferencial muito próximo dos eletrodos de captação. Na figura 9 mostra-se o diagrama esquemático de um amplificador diferencial. Os eletrodos de captação são compostos por duas barras de $\mathrm{Ag} / \mathrm{AgCl}$ dispostas paralelamente e distantes $1 \mathrm{~cm}$ entre si. Uma das sugestões para $\mathrm{o}$ posicionamento do eletrodo, é entre o ponto motor e o tendão de inserção do músculo, e as barras de captação do eletrodo devem estar perpendiculares às fibras musculares. Como foi utilizado um amplificador diferencial, faz-se necessário o uso de um eletrodo de referência, este eletrodo deve ter uma área de cerca de aproximadamente $4 \mathrm{~cm}^{2}$ e estar localizado em uma região sem músculos para não interferir na aquisição (DELSYS Inc, 2002).

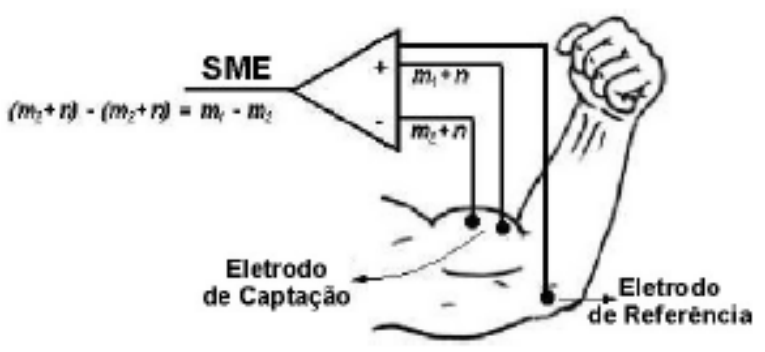

Figura 9. Amplificação diferencial, onde n representa o ruído do sistema e do ambiente e $\mathrm{m} 1$ - $\mathrm{m} 2$ o SME resultante.

\subsubsection{1- Considerações sobre os métodos de analise dos sinais.}

Após a captação do sinal de EMG este precisa ser tratado a fim de se observar as alterações fisiológicas decorrentes das contrações a que o músculo foi submetido. Na biomecânica existem dois tipos básicos de análises a que o sinal de EMG pode ser submetido:

(a) analise no domino do tempo do sinal;

(b) analise no domínio da freqüência do sinal.

A analise no domínio do tempo do sinal de EMG, permite principalmente a visualização do padrão de ativação muscular durante uma contração, podendo servir 
como referencia para comparações entre diferentes tipos de contrações, exercícios e sobrecargas. Este método permite ainda que relações entre força e atividade elétrica muscular possam ser observadas, apesar de ser uma vertente ainda controversa na literatura cientifica que aborda o assunto (MOHAMED et al., 2002; ONISHI et al., 1999).

A análise no domínio da freqüência basicamente permite que alterações fisiológicas relacionadas a fadiga periférica muscular sejam observadas. No estudo da biomecânica humana, os pesquisadores freqüentemente desejam ter meios para avaliar a fadiga de músculos que são envolvidos no desempenho de uma tarefa (DeLUCA, 1997).

Lindstron (1970) revelou que a redução da velocidade de condução do potencial de ação ao longo da fibra muscular causa uma alteração no espectro de freqüência do sinal de EMG. Basmajian e Deluca (1985) relataram que existi uma relação entre a velocidade de condução das fibras musculares com seu diâmetro e pH intramuscular. Sendo assim, é possível inferir que a velocidade de condução das fibras musculares diminui em fibras de contração rápida, pois mais lactato se acumula no músculo, diminuindo seu $\mathrm{pH}$, e conseqüentemente, a excitabilidade da membrana diminui, reduzindo a velocidade de contração das fibras musculares.

Através da Densidade Espectral de Potencia (DEP) do sinal de EMG, que demonstra o quanto de amplitude do sinal se encontra em quais freqüências, pode-se obter várias variáveis que refletem o mecanismo descrito por Lindrinston (1970), citado anteriormente (YAAR, 1989).

A variável mais comum utilizada nos estudos em biomecânica é a freqüência mediana (FMed) da DEP. A freqüência mediana é a freqüência na qual a densidade do espectro encontra-se dividida em duas regiões de igual área. Por se tratar do centro geométrico da DEP, é a freqüência característica que é mais sensível às variações tanto às altas quanto às baixas freqüências. Apesar disto, alguns autores também se utilizam do estudo da freqüência média (FM), que traduz simplesmente o ponto médio da DEP. No entanto as alterações nestas variáveis são diretamente relacionadas à velocidade de condução nas fibras musculares (STULEN \& DeLUCA, 1981).

O uso do sinal de EMG como índice de fadiga muscular tem interesse considerável, porque foi mostrado que o sinal exibe mudanças antes que ocorra 
qualquer modificação de força, sendo assim um indicativo do início da fadiga muscular (DeLUCA, 1997).

\subsection{O modelo biomecânico do joelho.}

O movimento humano pode ser descrito e modelado matematicamente com o objetivo de se compreender os mecanismos internos reguladores e executores do movimento. As descrições matemáticas de um determinado movimento devem ser precedidas por um modelo biomecânico do sistema osteomiarticular estudado, que deve contemplar todas as estruturas anatômicas envolvidas no movimento assim como a distribuição das forças e momentos articulares levando em conta uma referência bidimensional ou tridimensional (AMADIO, 1996; BAUMANN, 1995). Neste estudo as estruturas anatômicas de interesse são a articulação do joelho e o músculo quadríceps femoral, mais especificamente o músculo reto femoral (Figura 10 e 11).

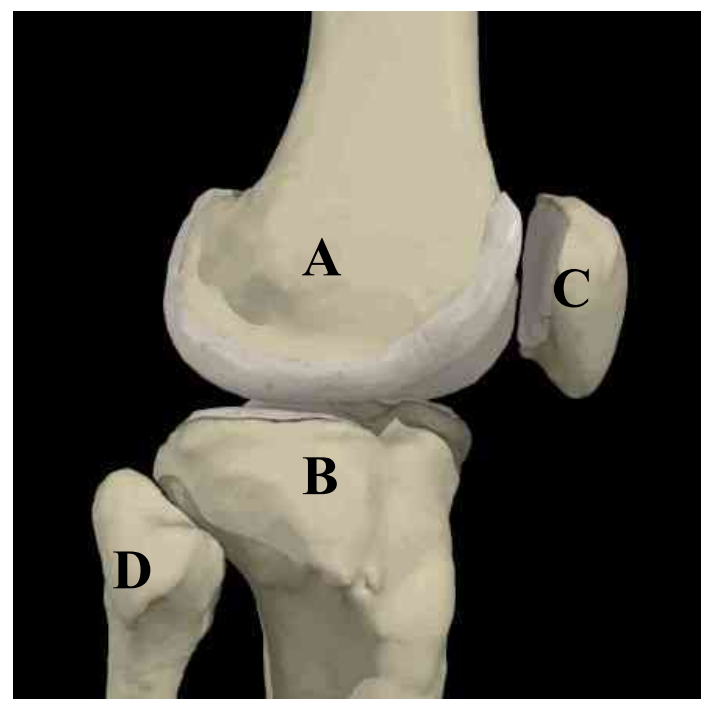

Figura 10. Vista sagital das estruturas ósseas que compõe a articulação do joelho: (A) côndilos femorais; (B) platô tibial; (C) Patela. A letra D se refere a cabeça proximal da fíbula, estrutura esta que não participa funcionalmente da articulação do joelho (Adapatado de Primal Pictures ${ }^{2}, 2003$ ). 


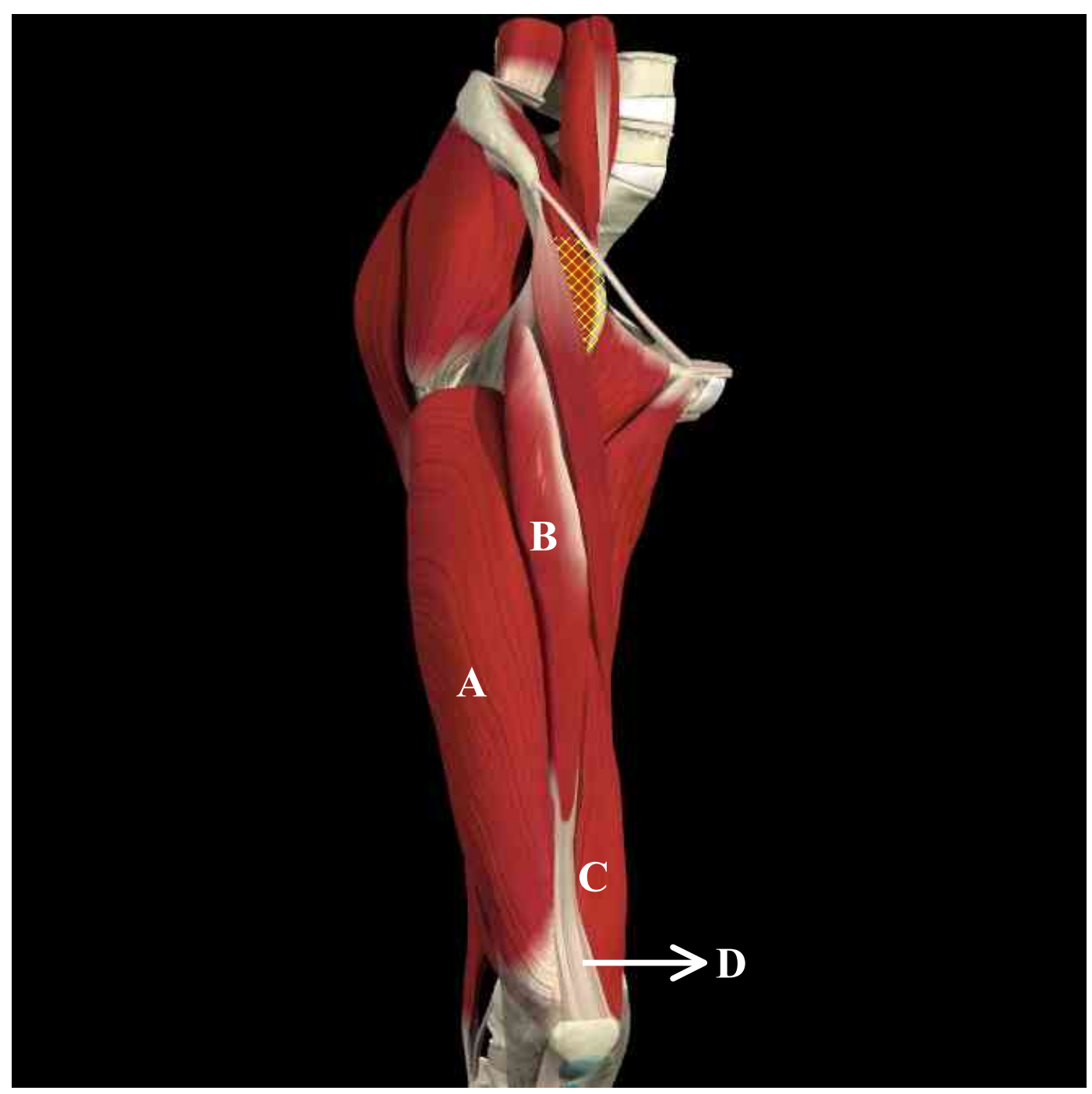

Figura 11. Vista frontal do músculo quadríceps femoral: (A) músculo vasto lateral; (B) músculo reto femoral; (C) músculo vasto medial; (D) tendão de inserção do músculo quadríceps na borda superior da patela (Adapatado de Primal Pictures ${ }^{2}, 2003$ ).

Os mecanismos de avaliação em biomecânica, exigem que um modelo biomecânico para a articulação do joelho seja adotado, para que os dados dinâmicos e cinemáticos adquiridos nos experimentos e gerados nas simulações possam ser analisados (BAUMANN, 1995). Para o desenvolvimento de um modelo biomecânico é necessário que alguns critérios sejam observados no sentido de se reduzir ao máximo os erros experimentais inerentes ao modelo.

A precisão de um modelo biomecânico de um segmento corporal está diretamente ligada a forma como o mesmo é obtido. Geralmente a obtenção de um modelo biomecânico, inicia-se com a observação de cadáveres. Com o avanço das tecnologias na área de instrumentação médica, os modelos biomecânicos dos segmentos 
do corpo humano estão cada vez mais precisos (GLITCH \& BAUMANN, 1997; YAMAGHUCHI \& ZAJAC, 1998).

Na situação proposta neste trabalho necessita-se de um modelo biomecânico que descreva a articulação do joelho. Kapandji (2000) define em seu livro que a articulação do joelho é a mais complexa, em termos mecânicos, do corpo humano e uma das mais simples em termos funcionais. Mesmo assim, a literatura científica apresenta vários modelos bidimensionais e tridimensionais desta articulação e que diferem em pequenos detalhes como, por exemplo, os que consideram a interação entre a patela e os côndilos femorais como sendo um sistema de alavancas, e aqueles que não (GLITCH \& BAUMANN, 1997; YAMAGHUCHI \& ZAJAC, 1998; VAN EIJDEN, 1998; KAPANDJI, 2000).

O modelo tridimensional apesar de fornecer informações mais detalhadas sobre as forças de ação muscular em um determinado sistema biológico, é muito complexo sendo que a sua principal aplicação na articulação do joelho é para a determinação das forças estáticas e dinâmicas de estruturas como, por exemplo, os ligamentos cruzados anterior e posterior e para a definição da topografia das superfícies articulares do fêmur e da tíbia (GLITCH \& BAUMANN, 1997; YAMAGHUCHI \& ZAJAC, 1998).

No caso específico deste estudo, onde o propósito é estudar a força gerada pelo quadríceps, a utilização de um modelo bidimensional sustenta metodologicamente os objetivos propostos. Justifica-se esta escolha por dois motivos: i) o desenvolvimento de um modelo biomecânico bidimensional é mais simples do ponto de vista do matemático; ii) as forças de ação dos dois principais músculos dinâmicos do quadríceps (reto femoral e vasto intermédio) apresentam suas fibras orientadas quase que em sua totalidade no plano sagital (figura 12) (GLITCH \& BAUMANN, 1997; YAMAGHUCHI \& ZAJAC, 1998; VAN EIJDEN, 1998; KAPANDJI, 2000).

Além do que, a identificação das contribuições independentes de cada músculo é uma tarefa praticamente impossível, visto que os componentes anatômicos (tendão) de transmissão das forças geradas pelas fibras musculares até a inserção, são fisicamente entrelaçados (DVIR, 2002). 
R.F.

T. P.

Figura 12. Orientação das forças de ação dos músculos: VMO - Vasto medial obliquo; VML e VLL-duas porções do músculo vasto intermédio; VLO - Vasto lateral; R. F. - reto femoral e T. P. tendão Patelar.

Um bom modelo biomecânico da articulação do joelho deve contemplar, ainda, dois fatores que são determinantes na qualidade dos resultados obtidos através das equações dinâmicas desenvolvidas para o modelo. Primeiro o modelo deve considerar que a articulação do joelho é policêntrica, sendo que para cada grau de flexão da articulação existe um eixo de rotação instantâneo diferente. Segundo, o modelo deve considerar a patela como uma alavanca (figura 13) com ponto de fixação variável que irá depender da translação dos côndilos femorais em relação ao platô tibial (VAN EIJDEN, 1998).

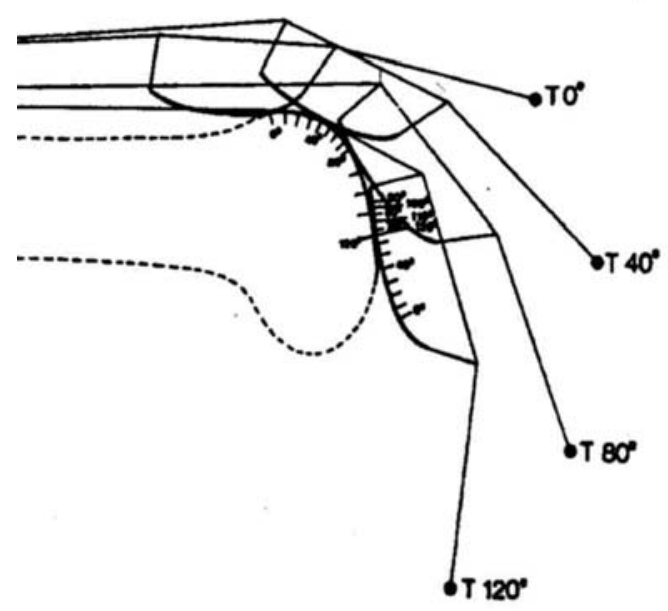

Figura 13. Esquema em corte sagital da articulação do joelho mostrando a alteração do ponto de contato da patela com os côndilos femorais em quatro posições angulares diferentes de flexão (Adaptado de Van Eijden, 1986). 
Pelos motivos apresentados anteriormente, para a execução deste estudo adotouse como base para o desenvolvimento do modelo biomecânico do joelho, o estudo de Van Eijden (1986) onde o autor propõe um modelo bidimensional. Apresenta também as variáveis antropométricas e geométricas necessária para a execução dos cálculos necessários para o propósito deste estudo. Um dos diferenciais do modelo de Van Eijden (1986) é que ele não apresenta apenas as descrições matemáticas do comportamento das suas estruturas, mas também a validação dos dados em função de medições realizadas em joelhos de cadáveres praticamente a fresco. Fato este que reflete de certa maneira uma preocupação do autor com o controle dos erros inerentes a aplicação ou adaptação deste modelo em situações experimentais ou simuladas, tentando dessa forma se aproximar ao máximo do comportamento real da articulação.

\section{6- Justificativa do estudo proposto.}

A aplicação do exercício isocinético traz importantes benefícios dentro dos quais cita-se, como exemplo, a capacidade que o equipamento tem de adaptar a sobrecarga em setores do movimento em que o paciente sente dor e a redução do tempo de treinamento. Além das características mecânicas citadas anteriormente no item 1.3.

Nos últimos tem se desenvolvido trabalhos científicos que buscam validar ferramentas alternativas, mais accessíveis, que representem, assim como o dinamômetro isocinético, uma maneira rápida e eficaz de se reabilitar um paciente em se tratando de treinamento muscular. Como exemplo cita-se o sistema de exercício para a articulação do joelho chamado de VariCom, desenvolvido por um grupo de pesquisa da África do Sul e que tem o objetivo se aproximar as características de sobrecarga do dinamômetro isocinético. O sistema VariCom utiliza, ao invés de um hardware eletrônico, um pistão hidráulico para realizar a limitação da velocidade do movimento (GRENBLATT et al., 2001).

Dentro desta busca de ferramentas alternativas ao dinamômetro isocinético, surgiu a prática, de que ao exercício com resistência elástica poderia ser classificado como isocinético, no entanto não há estudos que comprovam esta afirmação. A atribuição da qualidade isocinética à resistência elástica aparentemente surgiu da observação de que ela gera uma resistência variável em função do arco de movimento do exercício. 
Entende-se desta forma, que existe uma necessidade, inerente a aplicação clínica da resistência elástica, de se identificar as características biomecânicas de interação desta forma de sobrecarga com o músculo exercitado. $\mathrm{Na}$ literatura cientifica especializada encontram-se alguns trabalhos que, por exemplo, fazem análises eletromiográficas de músculos submetidos à resistência elástica e outros que estudam a sobrecarga que os materiais elásticos, utilizados na clínica, geram durante o exercício. No entanto, não existem estudos de tais exercícios caracterizando o comportamento biomecânico do músculo. Exceto os desenvolvidos anteriormente pelos autores deste trabalho (HINTERMEISTER et al., 1998a, 1998b; SIMONEAU et al., 2001; AZEVEDO et al., 2002, 2001,2000, 1999a , 1998; AZEVEDO,1999b).

Em trabalhos anteriores estudou-se, no Laboratório de Fisioterapia Aplicada ao Movimento Humano, do Departamento de Fisioterapia da UNESP de Presidente Prudente, a aplicação do exercício com resistência elástica ao músculo bíceps, este estudo preliminar mostrou a necessidade de uma qualificação completa das situações em que o exercício com a corda elástica é aplicado no cotidiano clinico. $\mathrm{O}$ fortalecimento do músculo quadríceps femoral é uma situação onde esta modalidade de exercício é bastante utilizada.

Neste contexto, busca-se fundamentalmente compreender qual o esforço muscular que esta submetido o músculo durante o exercício com as cordas elásticas. Com este intento propõe-se uma forma de aplicação padronizada do exercício e a tentativa de inferência do perfil da força exercida pelo músculo durante o exercício.A força muscular interna é avaliada através de um modelo ao qual aplica-se as simulações e as medidas externas, além da análise dos sinais EMG com a qual procura-se completar a caracterização do comportamento do músculo frente à aplicação desta modalidade de exercício.

O pano de fundo do presente trabalho é a necessidade do fisioterapeuta saber se o referido exercício pode ser caracterizado como isocinético. Esta foi a questão que abriu frente para o presente estudo, e acredita-se que com a conclusão do mesmo sua resposta esta contemplada. 
2. OBJETIVOS 


\section{OBJETIVOS}

O presente trabalho tem por objetivo:

a) Desenvolver um modelo biomecânico para o sistema de alavanca esquelética formada pelo fêmur, patela, articulação tíbio-femoral, e tíbia, incluindo as distribuições das forças musculares atuantes no movimento de extensão e flexão do joelho.

b) Caracterizar, através de simulações e experimentos, o comportamento mecânico do músculo quadríceps submetido a exercícios com a sobrecarga elástica comparando os resultados com a teoria isocinética.

c) Avaliar o comportamento do sinal mioelétrico do músculo reto femoral durante o exercício tanto no domínio do tempo quanto no da freqüência, quando submetido a exercícios com resistência elástica, correlacionando com a força muscular. 
3. MATERIAIS E MÉTODOS 


\section{3- MATERIAIS E MÉTODOS}

Neste trabalho utiliza-se um modelo biomecânico do joelho para a identificação da força interna gerada pelo quadríceps durante um exercício com resistência elástica.

Com base no modelo, realizaram-se simulações e experimentos para a identificação da força interna do quadríceps em sua inserção anatômica. Nos experimentos utilizaram-se como procedimentos de medidas a cinemetria e a dinamometria.

Os exercícios, experimentos, com a resistência elástica foram realizados em um sistema mecânico de exercício especialmente desenvolvido para este fim.

Também realizou-se o estudo eletromiográfico do músculo quadríceps durante os exercícios tanto no domínio do tempo quanto no da freqüência.

O modelo biomecânico e os procedimentos que envolveram a obtenção dos resultados neste estudo descrição completa nos itens que se seguem. 


\section{1 - Modelo biomecânico do joelho}

Com base no modelo biomecânico da articulação do joelho proposto por Van Eijden (1986), identificou-se a força gerada pelo músculo quadríceps, durante o exercício em um sistema mecânico com resistência elástica, em função de parâmetros dinâmicos cinemáticos e antropométricos. O sistema mecânico no qual o exercício foi realizado foi construído especificamente para este fim, de modo a permitir que a tensão elástica fosse aplicada na altura do tornozelo sempre perpendicular ao eixo da tíbia. As forças externas e os torques atuantes nesta situação de exercício são apresentados na figura 14 .

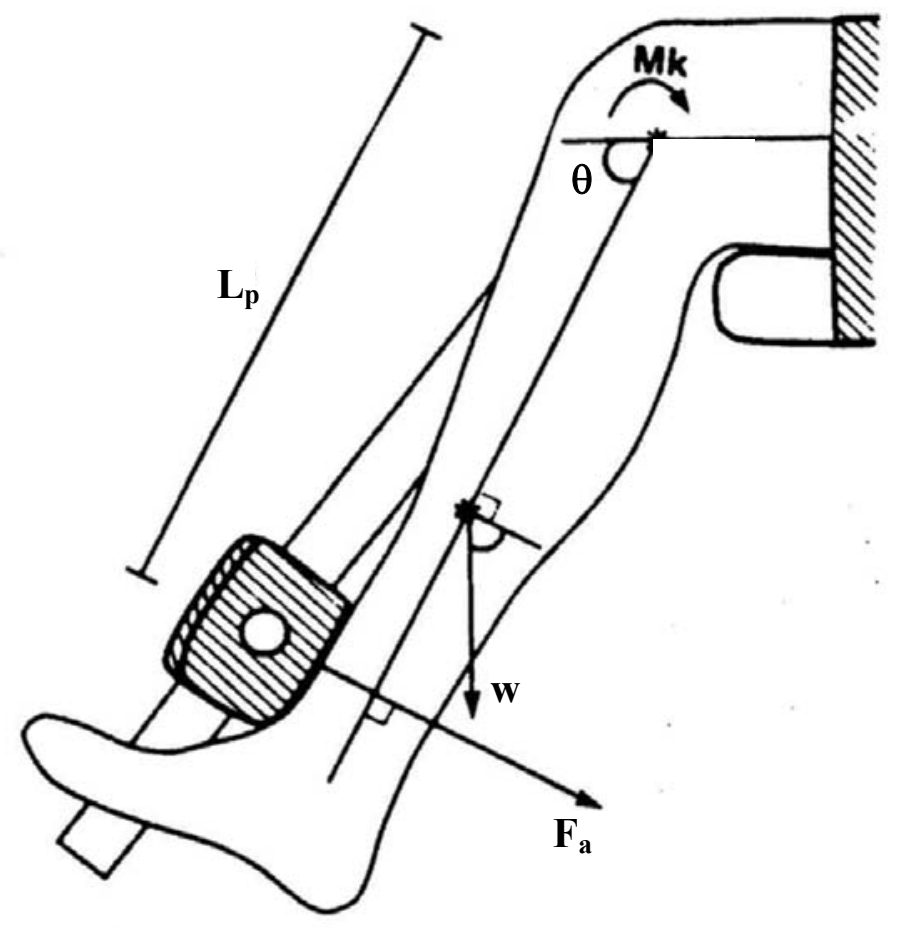

Figura 14. Forças externas e torque atuante na situação de exercício representada no esquema. Onde $F_{a}$ é a tensão gerada pela resistência elástica; $w$ é o peso da perna; Mk é o torque gerado na articulação do joelho pela força do quadríceps; $\theta$ é o Ângulo de flexão do joelho e $L_{p}$ é o comprimento da perna; adaptado de Dvir, 2002.

Com base na situação de exercício demonstrada acima, determina-se a distribuição das forças internas de interesse para o estudo, e a geometria e os ângulos de 
ação destas forças. O diagrama de corpo livre (figura 15), representando a perna de um sujeito, apresenta estas variáveis.

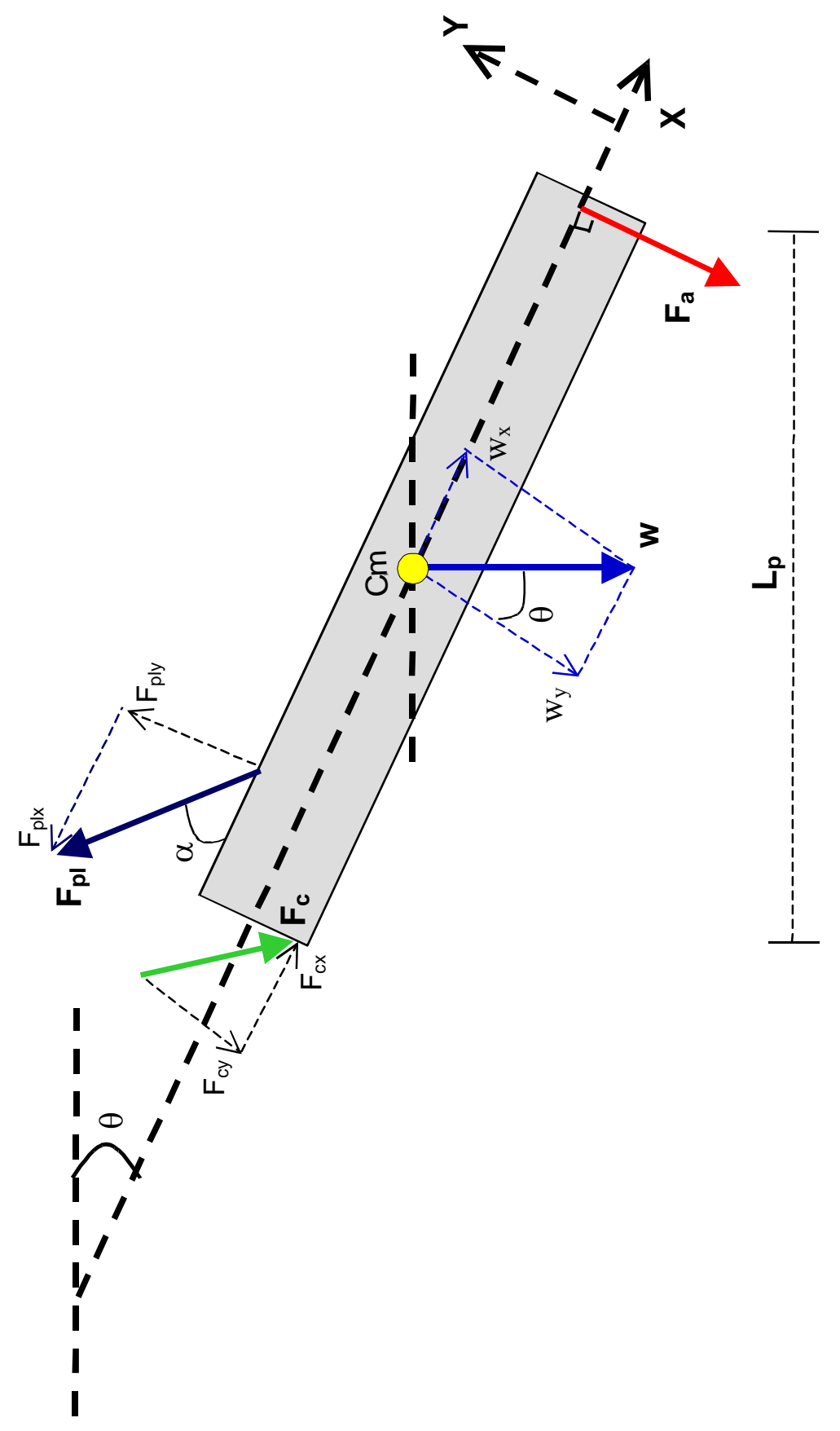

Figura 15. Diagrama de corpo livre demonstrando as forças atuantes no sistema e seus respecticos ângulos de ação; $F_{c}-$ Força de contato articular; $F_{p l}-$ Força do tendão infrapatelar na tuberosidade da tíbia; $w$ - Peso da perna; $F_{a}-$ Força de aplicação da resistência elástica; $\theta$ - ângulo entre o eixo tíbia e a horizontal; $\alpha$ - Ângulo entre o tendão infrapatelar e o eixo da tíbia; $L_{p}-$ Comprimento da perna e $\mathbf{C m}$ - Centro de massa da perna. 
Quando o sistema se move com velocidade angular constante, ou seja, quando a aceleração é zero tem-se que o somatório das das forças e dos momentos é igual a zero $(\Sigma \mathbf{F}=\mathbf{0}$ e $\Sigma \mathbf{M}=\mathbf{0})$. Baseando-se neste principio impôs-se a condição, simulada e experimental, de exercício em que não existem componentes de aceleração durante todo arco de movimento da articulação do joelho. A adoção desta situação permitiu a elaboração das equações que descrevem o equilíbrio dinâmico das forças atuantes nos eixos $\mathrm{X}$ e Y da alavanca demonstrada no digrama da figura 15. Além disso, a adoção da condição de velocidade constante simula em parte a condição imposta pelo dinamômetro isocinético.

$(\Sigma \mathbf{F}=\mathbf{0})$

$$
\begin{gathered}
-F_{c y}-w \cdot \cos (\theta)-F_{A}+F_{p l} \cdot \operatorname{sen}(\alpha)=0 \\
F_{c x}+w \cdot \operatorname{sen}(\theta)-F_{l p} \cdot \cos (\alpha)=0
\end{gathered}
$$

O modelo demonstra que a determinação da variação do ângulo de inserção do ligamento infrapatelar $(\alpha)$ em função da posição da perna, é indispensável para a obtenção dos valores de força aplicada na tuberosidade da tíbia. Mas a determinação desta dependência deve levar em conta que o ângulo $\alpha$ varia em função do ângulo de flexão do joelho $(\theta)$ e da translação dos côndilos femorais em função do platô tibial (distancia $\mathrm{R}_{\mathrm{x}}$, figura 16 ).

A translação do côndilo femoral em relação ao platô tibial faz com que o ponto de apoio da patela sobre os côndilos femorais varie de acordo com a posição de flexão do joelho, tal fator interfere diretamente na relação entre a geração de força do músculo quadríceps e a força aplicada pelo tendão infrapatelar na tuberosidade da tíbia. A figura 16 ilustra as relações geométricas existentes nas interações entre os côndilos femorais e o platô tibial na articulação do joelho.

Com base nestas relações geométricas tem-se que o equilíbrio dinâmico dos torques, que efetivamente geram rotação no segmento (eixo Y), é dado pela equação 4.

$$
\left(\Sigma \mathbf{T}_{\mathbf{y}}=\mathbf{0}\right)
$$

$$
F_{p l .} \operatorname{sen}(\gamma) \cdot \mathbf{R}+\mathbf{w} \cdot \cos (\theta) \cdot \mathbf{C m}+\mathbf{F}_{\mathrm{A}} \cdot \mathbf{L}_{\mathrm{p}}=0
$$




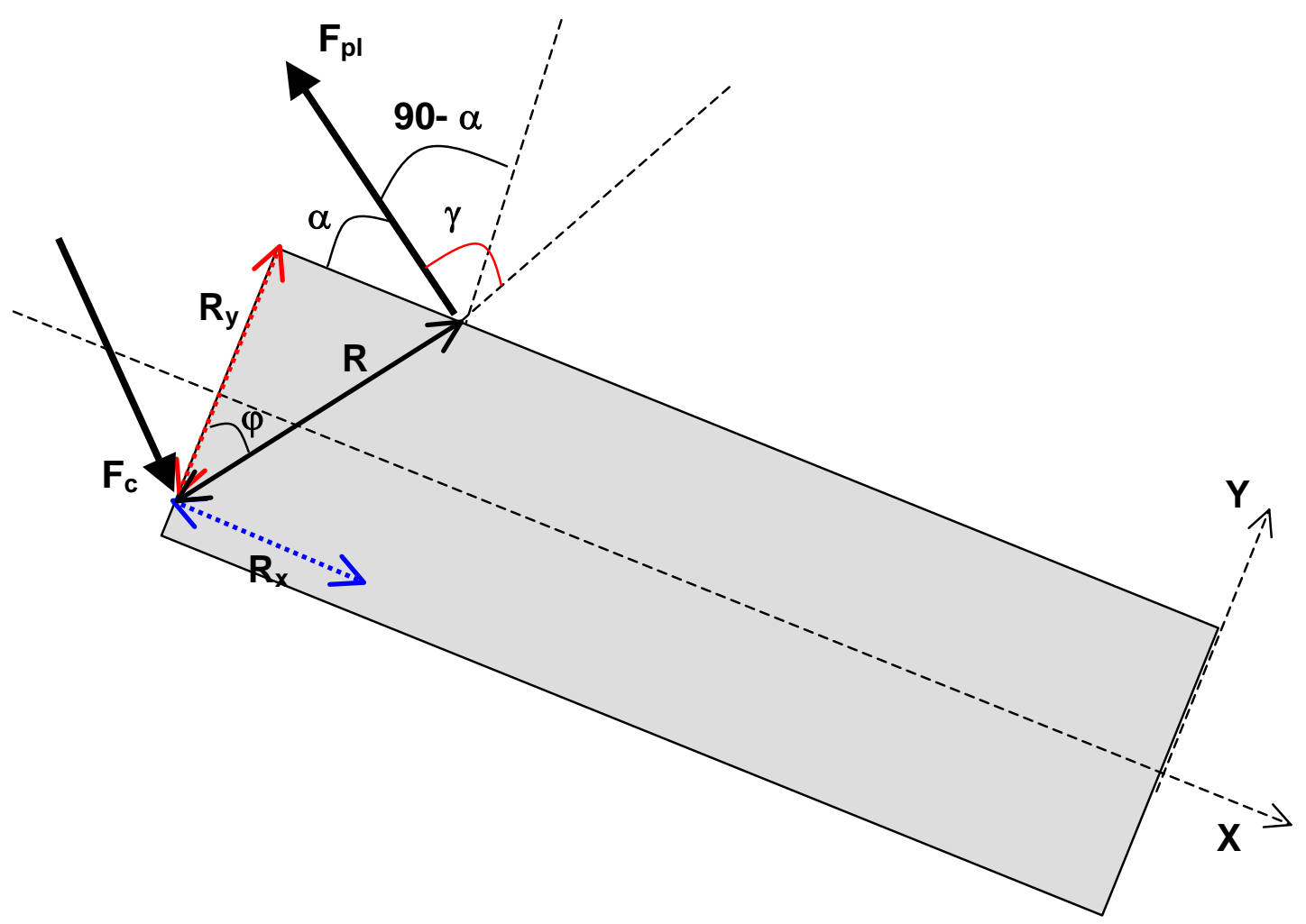

Figura 16. Esquema mostrando as relações entre a translação do côndilo femoral em relação ao platô tibial e a alteração das distâncias dos braços de força e ângulos durante o movimento de

flexão do joelho, onde: $R_{x}$ - Distância entre o platô tibial e a tuberosidade da tíbia; $R_{y^{-}}$

Comprimento da translação do côndilo femoral em ralação a tíbia; $\mathbf{R}$ - Distância perpendicular do ponto de contato articular até a ação da força do tendão infrapatelar.

Desenvolvendo a equação 4, tem-se que a força exercida pelo ligamento infrapatelar na tuberosidade ta tíbia é dada pela equação 5.

$$
\mathrm{F}_{\mathrm{pl}}=\frac{w \cdot C m \cdot \cos \theta+\cdot F_{a} \cdot L_{p}}{R \cdot \operatorname{sen} \gamma}
$$


A força aplicada pelo tendão infrapatelar na tuberosidade da tíbia não reflete nominalmente a força gerada pelo músculo quadríceps, aplicada na borda superior da patela através do tendão suprapatelar. Deve-se este fato a ação mecânica da patela no contexto da dinâmica da articulação do joelho.

Como citado anteriormente, a patela funciona como uma alavanca que pode tanto otimizar a força gerada pelo quadríceps como também proporcionar o efeito contrário, durante a extensão e a flexão do joelho respectivamente. Esta função mecânica só é possível, pois o ponto de apoio da patela, em relação aos côndilos femorais, mudam de posição conforme o movimento de extensão e flexão da articulação.

Dessa forma torna-se necessário, para o cálculo da força nominal gerada pelo quadríceps, o conhecimento da relação da força gerada pelo músculo e a aplicada na tuberosidade da tíbia $(\mathrm{Fpl} / \mathrm{Fq})$ levando-se em conta o comportamento mecânico da interface entre estas duas forças, representada pela patela. Esta relação (figura 17), foi obtida a partir do modelo proposto por Van Eidjin (1986). A equação 6 demonstra a força gerada pelo quadríceps durante o exercício.

$$
\mathrm{F}_{\mathrm{q}}=\frac{w \cdot C m \cdot \cos \theta+\cdot F_{a} \cdot L_{p}}{R \cdot r \cdot \operatorname{sen} \gamma}
$$

onde:

$r=\frac{F p l}{F q}$ é a relação entre a força gerada pelo quadríceps e a força exercida pelo tendão infrapatelar na tuberosidade da tíbia obtida pelo do ajuste, usando um polinômio de quarto grau, da curva fornecida pelo modelo de Van eidjin (1986) (figura 17).

O valor de $\gamma$ foi obtido através das relações trigonométricas presentes na figura 16 e é dado pela equação 7 . 


$$
\gamma=\left(\operatorname{arctg} \frac{R_{x}}{R_{y}}\right)-\alpha+90
$$

O valor de $\alpha$ também foi obtido através do ajuste, utilizando um polinômio de quarto grau, da curva fornecida pelo modelo de Van Eidjin (1986) (figura 18).

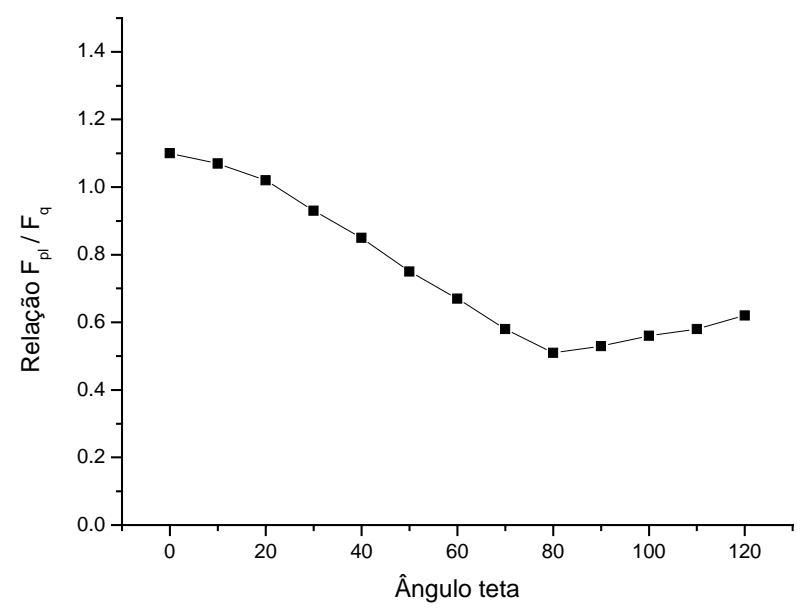

Figura 17. Gráfico mostrando a relação entre a força gerada pelo músculo quadríceps e a força resultante na sua inserção na tuberosidade da tíbia em função do ângulo de flexão do joelho; adaptado de Van Eidjin, (1986).

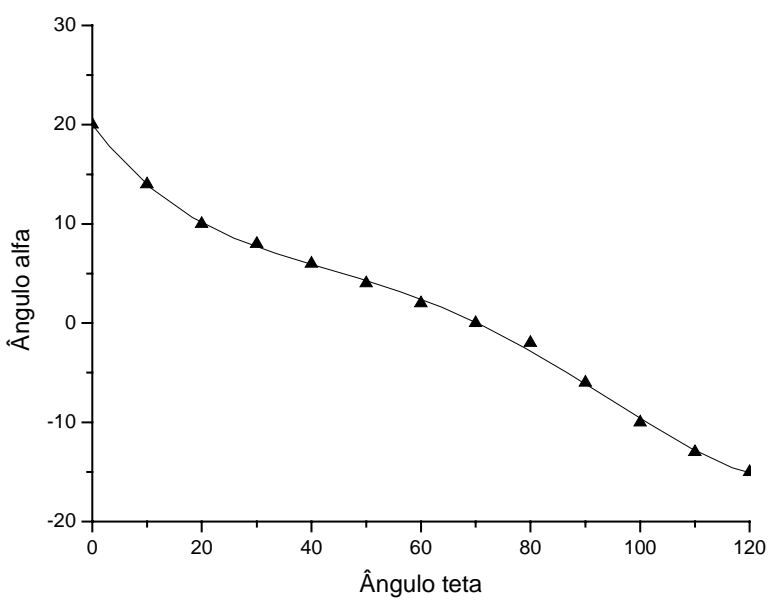

Figura 18. Gráfico mostrando a variação do ângulo formado entre o tendão infrapatelar e o eixo da tíbia $(\alpha)$; adaptado de Van Eidjin, (1986). 
$\mathbf{R}_{\mathbf{y}}$ que representa a distância percorrida pelos côndilos femorais sobre o platô tibial durante o movimento articular, foi obtido através da observação de dois joelhos dissecados, glicerinados, pertencentes ao Laboratório de Anatomia do Departamento de Fisioterapia da UNESP de Presidente Prudente. Os joelhos apresentavam os ligamentos cruzado anterior, posterior, o colateral e o colateral médio íntegros.

Realizou-se sete medidas em ângulos de flexão do joelho diferentes. Para cada ângulo a distância percorrida pelo ponto de contato do côndilo no platô tibial era marcada, para isso foi considerado como referencia em ambos os joelhos o côndilo medial. Após a obtenção dos dados os mesmos foram ajustados para a obtenção da função que descreve a translação dos côndilos. A figura 19 mostra os dados obtidos no procedimento descrito.

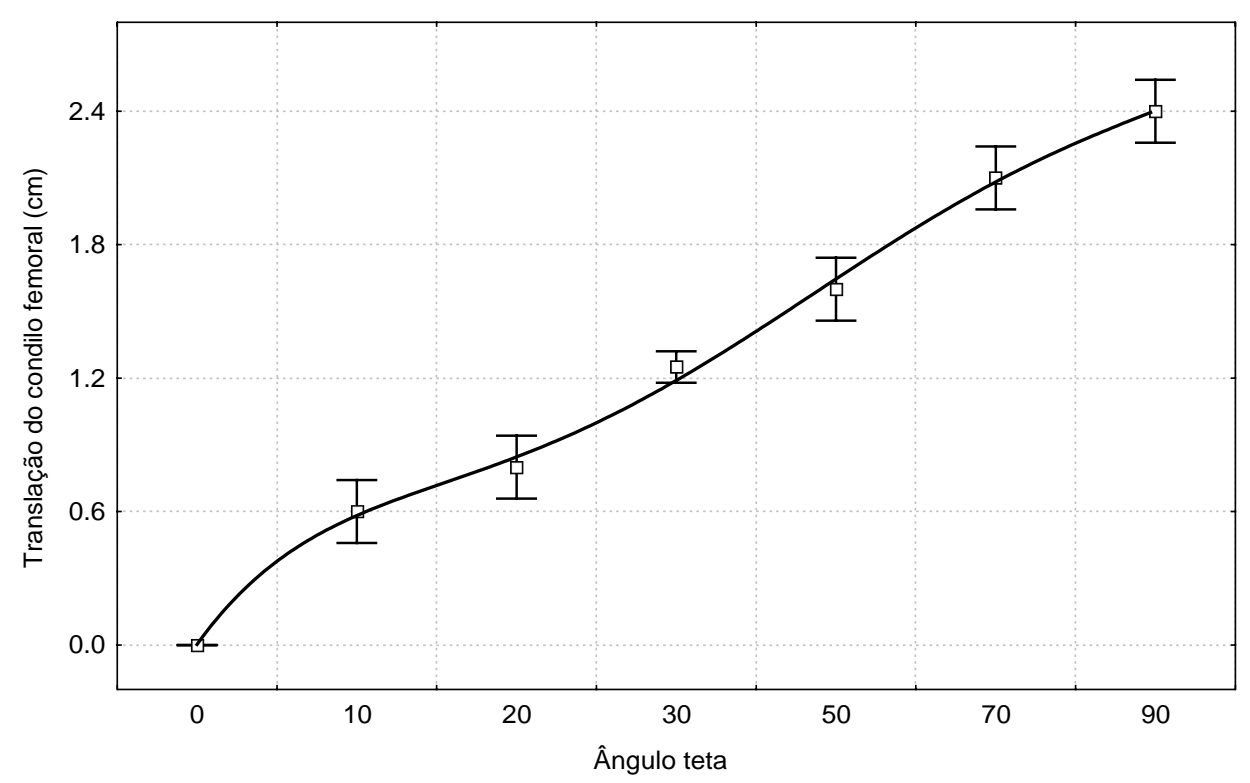

Figura 19. Translação do côndilo femoral em relação ao platô tíbia $\left(R_{y}\right)$ em função do ângulo de flexão da articulação do joelho( $\theta)$. 


\section{2 - Sistema de mecânico de exercício.}

Foi desenvolvido um sistema mecânico de exercício, para a aplicação da resistência elástica durante os exercícios nos sujeitos selecionados para o experimento. O desenvolvimento sistema foi feito em parceria com a escola técnica SENAI, unidade de Presidente Prudente (figura 20). Este apresenta uma base de fixação chumbada ao chão; uma roda com raio de $350 \mathrm{~mm}$ com um sulco de $30 \mathrm{~mm}$ em todo o seu perímetro; um eixo de rotação provido de um rolamento para a fixação da roda ao pilar de sustentação; uma alavanca com comprimento ajustável e uma manopla para o apoio do membro. São também acoplados ao sistema, um eletrogoniometro e um sensor de velocidade tangencial da roda.

O sistema desenvolvido permite padronizar a execução do exercício. O principal ponto observado é que o sistema anula a variação do ângulo formado pela corda elástica e o eixo axial da perna do sujeito, fato que ocorre em uma situação de aplicação clínica, pois a corda elástica é amarrada diretamente ao tornozelo do paciente. No sistema, a tensão gerada pela corda se mantém perpendicular ao eixo axial da perna do sujeito durante todo o arco de movimento.

Observa-se na figura 20 que a corda elástica não é presa diretamente no sistema de exercício. Justifica-se tal procedimento, para se evitar o atrito do material elástico com a superfície da caneleta da polia.

Nas equações dinâmicas demonstradas no item anterior, não considerou-se o momento de inércia da polia do sistema de exercício.

\section{3- Tubos elásticos.}

3.3.1- Equações que descrevem a tensão gerada pelo tubo durante os exercícios no sistema de tração (simulações).

Para a realização das simulações no que diz respeito à força gerada pelo quadríceps é necessário que se simule também a tensão gerada pela corda elástica durante o exercício. De modo geral a tensão gerada por um material elástico durante uma situação de estiramento é dada pela expressão: 


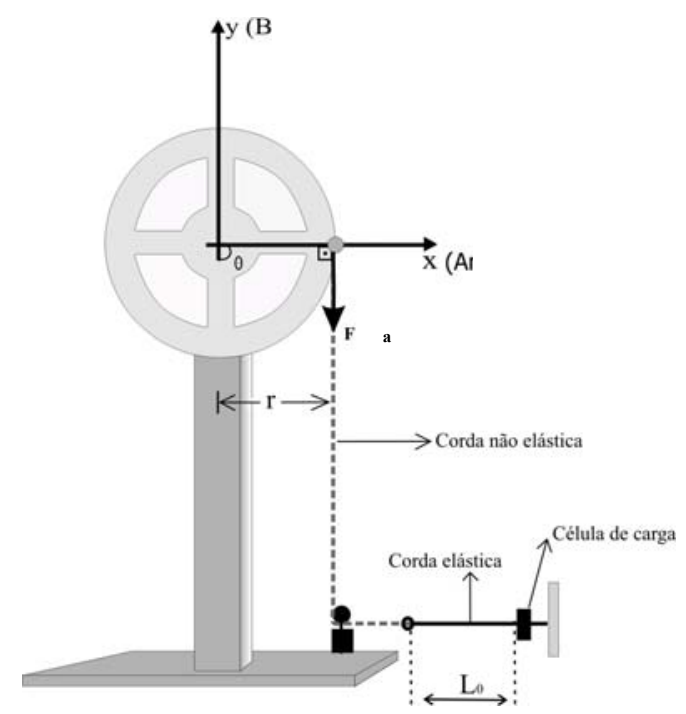

Figura 20. Montagem do sistema de tração para a realização dos exercícios.

$$
F=\gamma A \cdot \frac{\Delta L}{L_{0}}
$$

onde:

$\gamma \mathrm{A}=$ Constante relacionada com a área de aplicação da força de deformação e com módulo de young do material (VLACK, 1970).

$\mathrm{L}_{0}=$ Comprimento inicial da corda.

$\Delta \mathrm{L}=$ Variação do comprimento da corda durante o estiramento.

É importante ressaltar que a tensão gerada pela corda é diretamente proporcional ao ângulo do setor que o sujeito desloca durante a execução do exercício. Dessa forma, aplicando a equação 8 na situação em que a corda será tencionada através do sistema de tração, temos que a força aplicada $\left(\mathbf{F}_{\mathbf{a}}\right)$ no tornozelo no voluntário será determinada pela equação: 


$$
F_{a}=\frac{\gamma A}{L_{0}} \cdot\left(\frac{\pi}{2}-\theta\right) \cdot \frac{r^{2}}{L_{p}}
$$

onde:

$\mathbf{r}=$ Raio da polia do sistema de tração $(35 \mathrm{~cm})$.

\subsection{2- Caracterização mecânica dos tubos elásticos.}

O fator de elasticidade $(\gamma \mathbf{A})$ pela área do material, é dado pelo produto do modulo de Young $(\gamma)$ do material pela área $(\mathbf{A})$ de aplicação da força de deformação.

Três tubos elásticos da marca Lengruber (Figura 21) foram submetidos a ensaios de tração em uma máquina de ensaios mecânicos (EMIC), do Laboratório de Polímeros do Departamento de Física Química e Biologia da FCT - UNESP de Presidente Prudente. Obteve-se destes ensaios as curvas de tensão em função da deformação mostradas na figura 22.

Nas simulações adotou-se o comportamento de cordas ideais considerando que a tensão gerada é linearmente proporcional à deformação da corda. Esta situação ideal não é observada na abordagem experimental. Como demonstrado na figura 22, os tubos apresentam linearidade até 300\% de deformação.

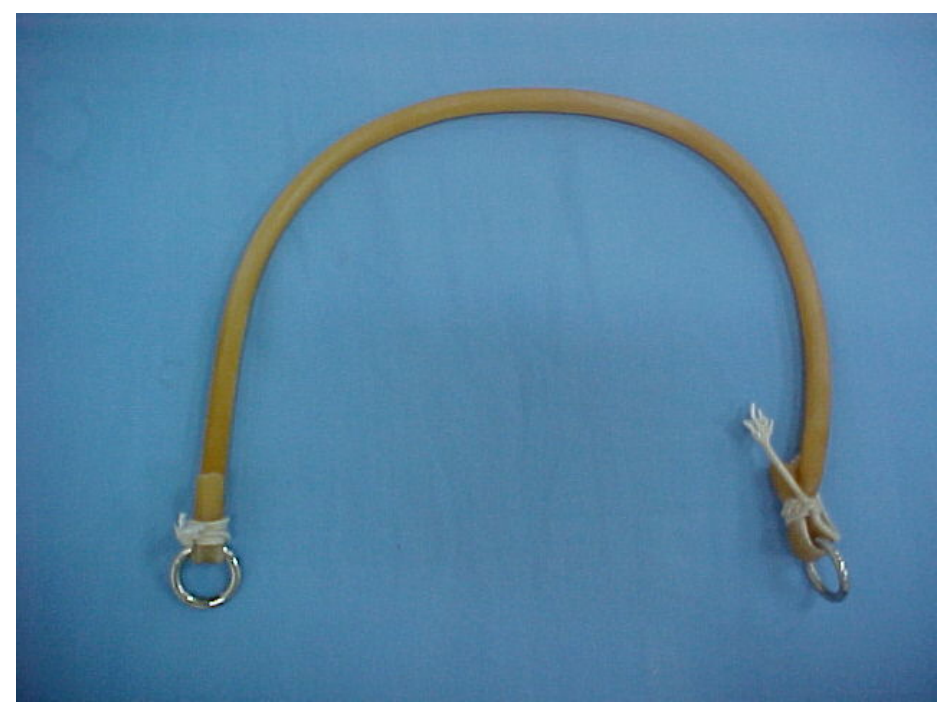

Figura 21. Tubo de látex utilizado para confecção das cordas elásticas utilizadas na situação experimental. 


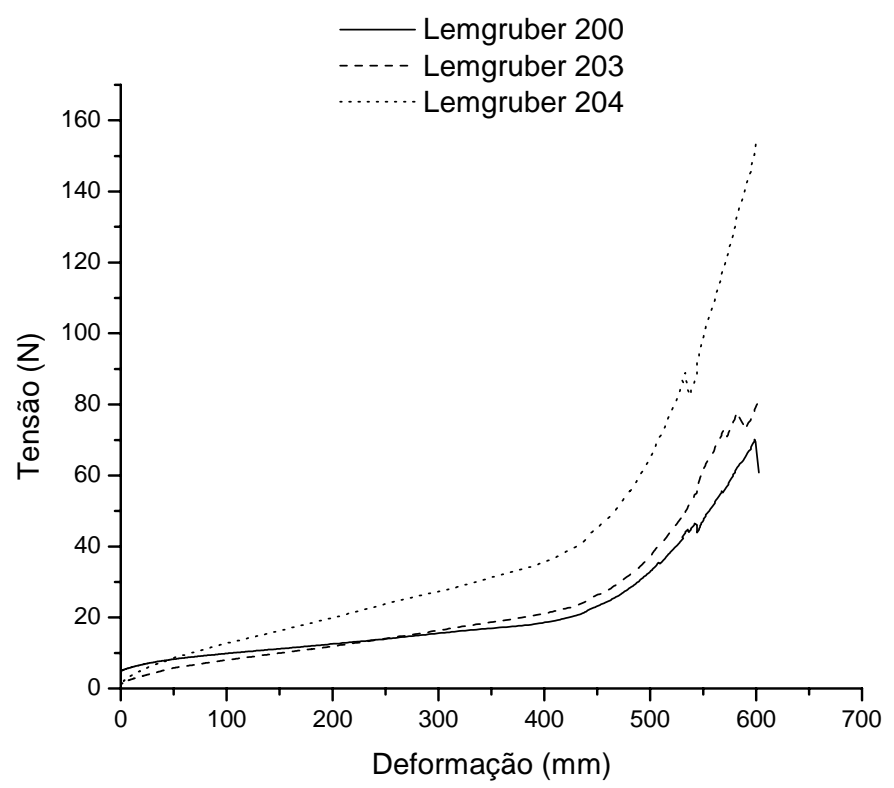

Figura 22. Curva de tensão em função da deformação, obtidas através da maquina de ensaios mecânicos (EMIC), para três tubos de látex diferentes.

Para melhorar a relação entre os resultado obtidos nas simulações e os resultados que serão obtidos nos experimentos, calculou-se o valor de $\gamma \mathbf{A}$ de cada corda nas regiões de comportamento linear (figura 23) utilizando a expressão:

$$
\gamma A=K \cdot L_{0}
$$

onde:

$\mathrm{K}=$ constante elástica da corda, pode ser obtida através da derivação da curva tensão pela deformação do tubo de látex (figura 24). 


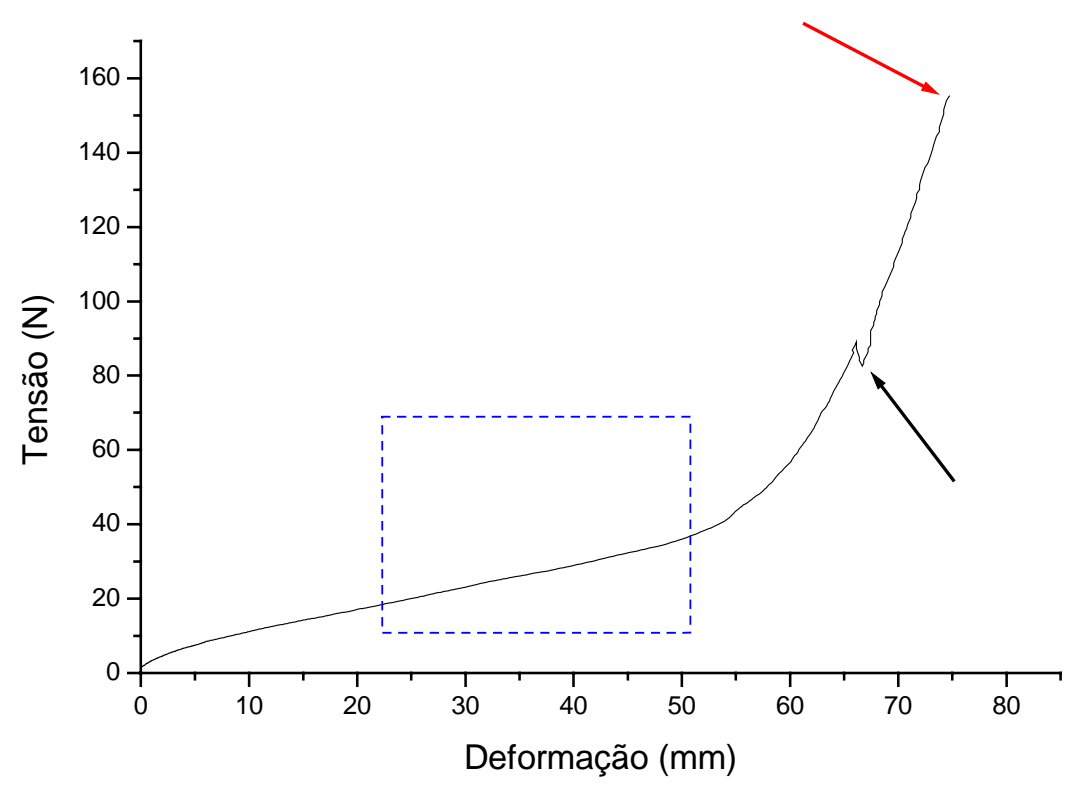

Figura 23. Curva de tensão pela deformação de uma amostra Lengruber 204. O retângulo demarca a região linear, a seta vermelha mostra a tensão máxima de ruptura da amostra e a seta preta mostra um ponto de falha estrutural.

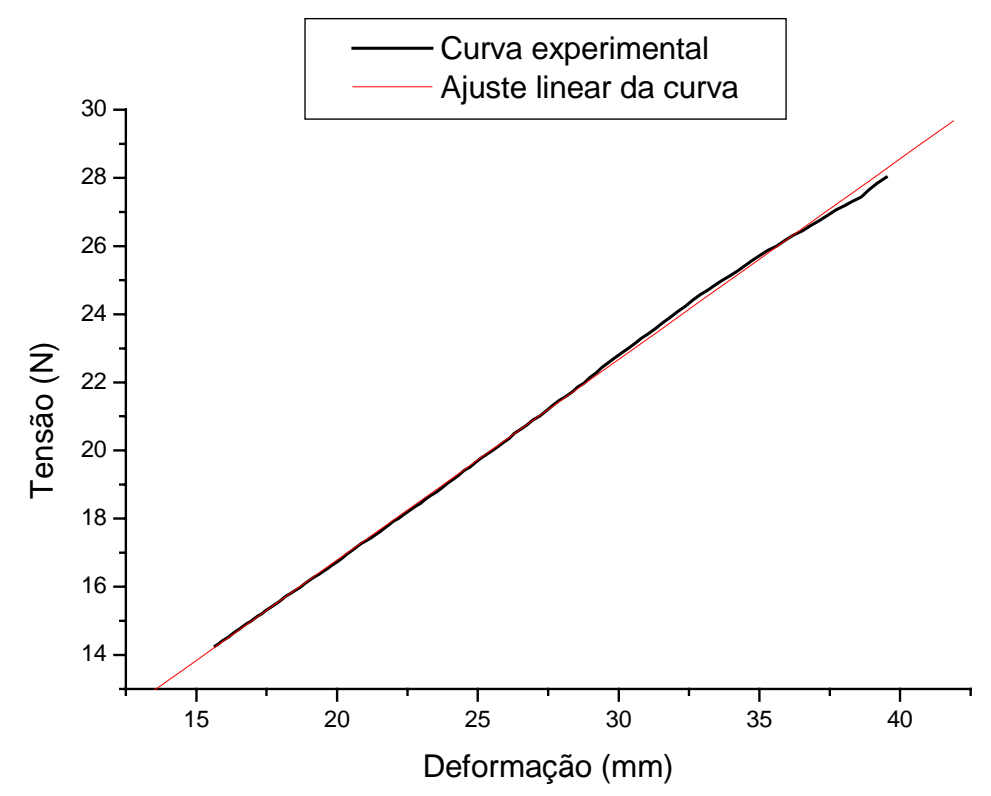

Figura 24 - Ajuste linear da região delimitada pelo retângulo azul (figura 22), K= 0,22N/m. 
Aplicando-se valor de K, para esta amostra, por exemplo, na equação 10 tem-se que o fator de elasticidade $(\gamma \mathbf{A})$ do tubo de látex Lengruber No. 204 é igual a $11 \mathrm{~N}$. No entanto devido a má qualidade de fabricação dos tubos estes valores nunca são exatamente iguais para cordas de mesmo número, fator que pode prejudicar a qualidade dos resultados experimentais.

Com base nas observações experimentais do comportamento mecânico dos tubos elásticos, entende-se que um estiramento superior a 300\% do seu comprimento inicial aproxima-se do limite de operação da corda, provocando a perda das propiedades elásticas com maior rapidez. É importante que durante o exercício a corda elástica seja estirada dentro de sua região linear, por este motivo na situação experimental de exercício, este padrão foi respeitado.

\section{4- Modelo Experimental}

\subsection{1- Modelo Antropométrico e Sujeitos}

O modelo antropométrico adotado neste estudo, para a obtenção dos valores do peso, comprimento e do centro de massa da perna, foi o proposto por Zatsiorsky \& Seluyanov (1983).

Zatsiorsky (1984), estudou uma amostra de 100 homens e 16 mulheres com peso de aproximadamente $73 \mathrm{Kgf}( \pm 9,0)$ e altura de $174,1 \mathrm{~cm}( \pm 6,2)$. Dessa forma preconiza-se que a aplicação do modelo é valida em sujeitos que estejam enquadrados dentro destes limites. Com base nestes estudos Leva (1996) propõe que o segmento da perna de homens, que se enquadram nas características antropométricas citadas anteriormente, apresentam um comprimento longitudinal de $393,4 \mathrm{~mm}$, sendo que o centro de massa se localiza a $44,9 \%$ do comprimento longitudinal total do segmento e o seu peso é igual a $4,33 \%$ do peso corporal total do sujeito.

Baseando-se nestes dados, cinco sujeitos do sexo masculino, destros, sem antecedentes de lesões no joelho direito e com características antropométricas descritas na tabela 1, foram submetidos ao exercício no sistema mecânico.

Todos os sujeitos foram esclarecidos com relação ao procedimento experimental, e assinaram um termo de consentimento. 
Tabela 1 - Características antropométricas dos voluntários submetidos ao exercício.

\begin{tabular}{ccc}
\hline Sujeitos & Massa (Kgf) & Altura (cm) \\
\hline $\mathbf{1}$ & 80 & 180 \\
2 & 76 & 178 \\
3 & 84 & 176 \\
4 & 78 & 181 \\
5 & 82 & 178 \\
Médias & $\mathbf{8 0}( \pm \mathbf{3 . 1 6})$ & $\mathbf{1 7 8 . 8}( \pm \mathbf{2 . 2 8})$ \\
\hline
\end{tabular}

\subsection{2- Aquisição dos dados dinâmicos e cinemáticos.}

Os voluntários foram posicionados sentados em uma cadeira com regulagem de altura de modo que a articulação do joelho ficasse alinhada ao eixo de rotação do sistema de tração, como demonstrado nas figuras 25 e 26.

Após o posicionamento do voluntário o mesmo foi orientado a realizar 10 ciclos de flexão e extensão do joelho, partindo de $90^{\circ}$ (posição de repouso) até $0^{\circ}$, voltando a $90^{\circ}$, concluindo um ciclo. A aquisição dos dados relativos aos 10 ciclos foi realizada procurando se manter velocidade angular constante na contração concêntrica e excêntrica. Para tal, o voluntário teve o auxílio de um metrônomo digital, que marcava um ritmo de $2 \mathrm{~Hz}$ e um sensor de velocidade que proporcionava o controle da velocidade por feedback, esta instrumentação será melhor detalhada no item 3.5.

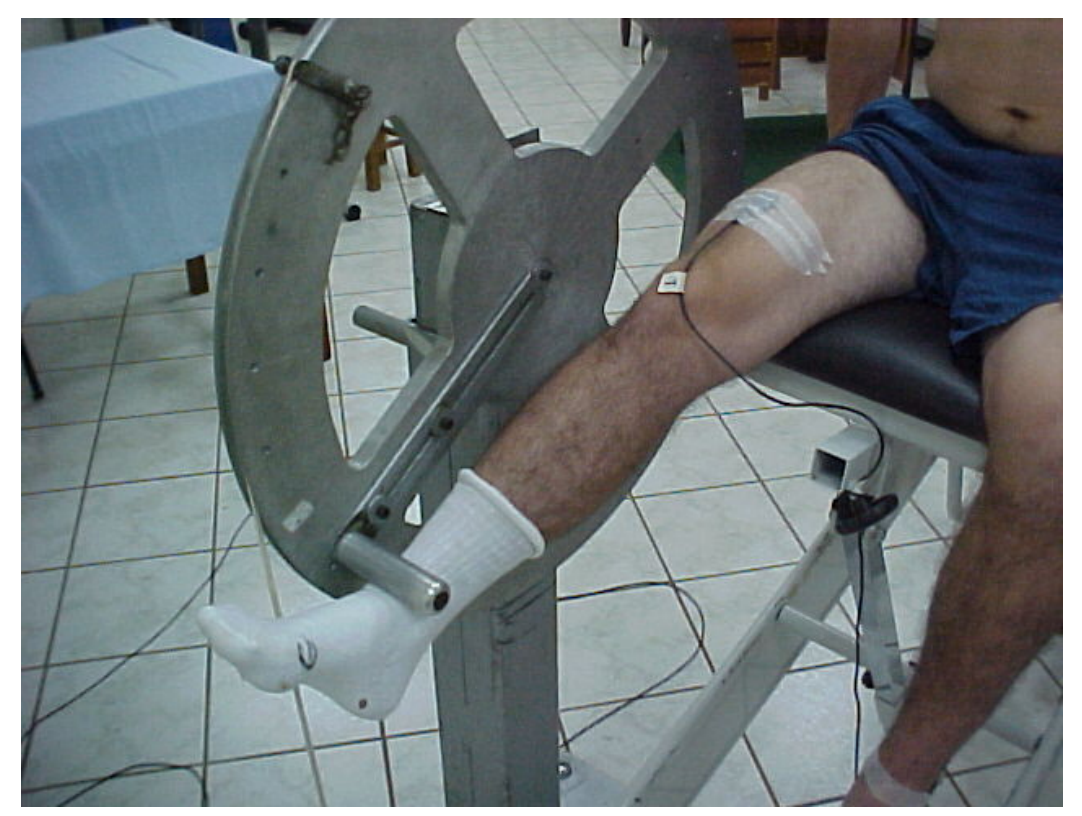

Figura 25. Voluntário posicionado, realizando o movimento de extensão da perna (vista lateral). 


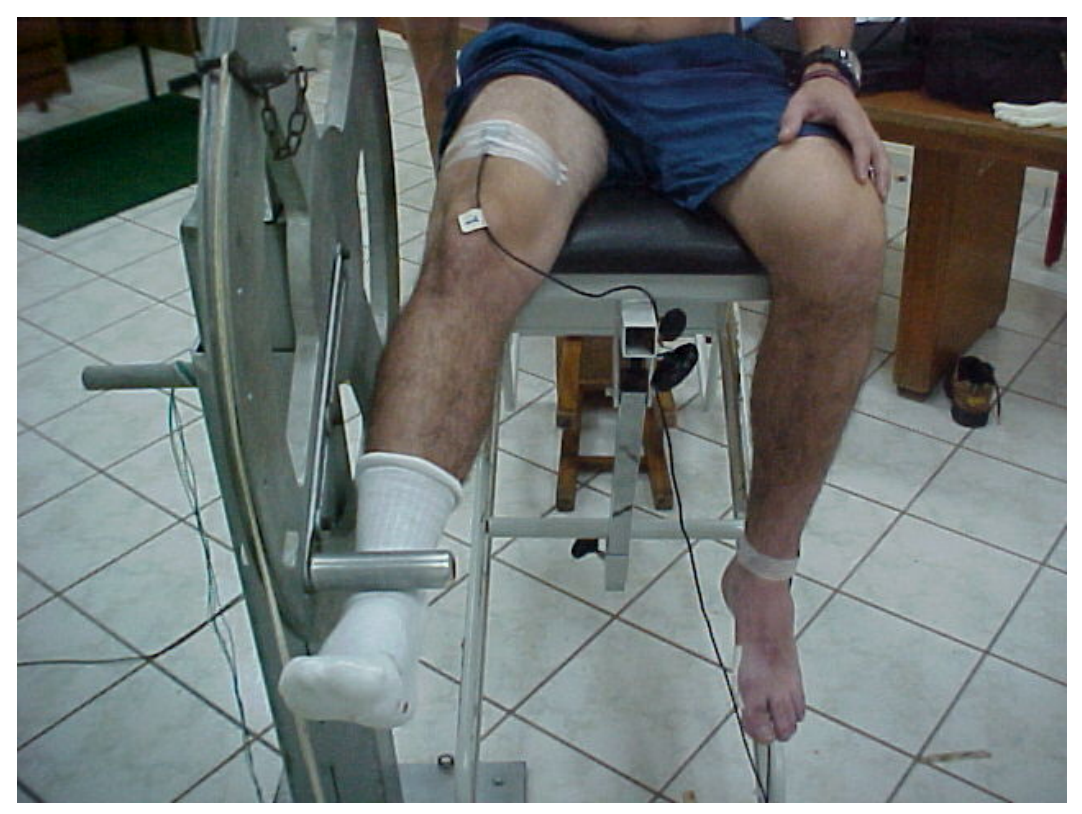

Figura 26. Voluntário posicionado, realizando o movimento de extensão da perna (vista anterior).

\subsection{3- Protocolo de exercício para a aquisição dos sinais de EMG.}

Para a captação dos sinais EMG do músculo reto femoral durante a realização do exercício com a resistência no sistema de tração, os sujeitos foram posicionados da forma descrita no item 1.4.1, e o eletrodo foi fixado com fita adesiva sobre o músculo reto femoral (figura 27) sendo que a área de contato foi devidamente tricotomizada e limpa (DeLUCA, 1997; WINTER, 1990). O sujeito foi orientado a executar o exercício até que fosse observado um déficit de força muscular representado, nesse caso, pela incapacidade do sujeito em completar totalmente o arco de movimento proposto . 


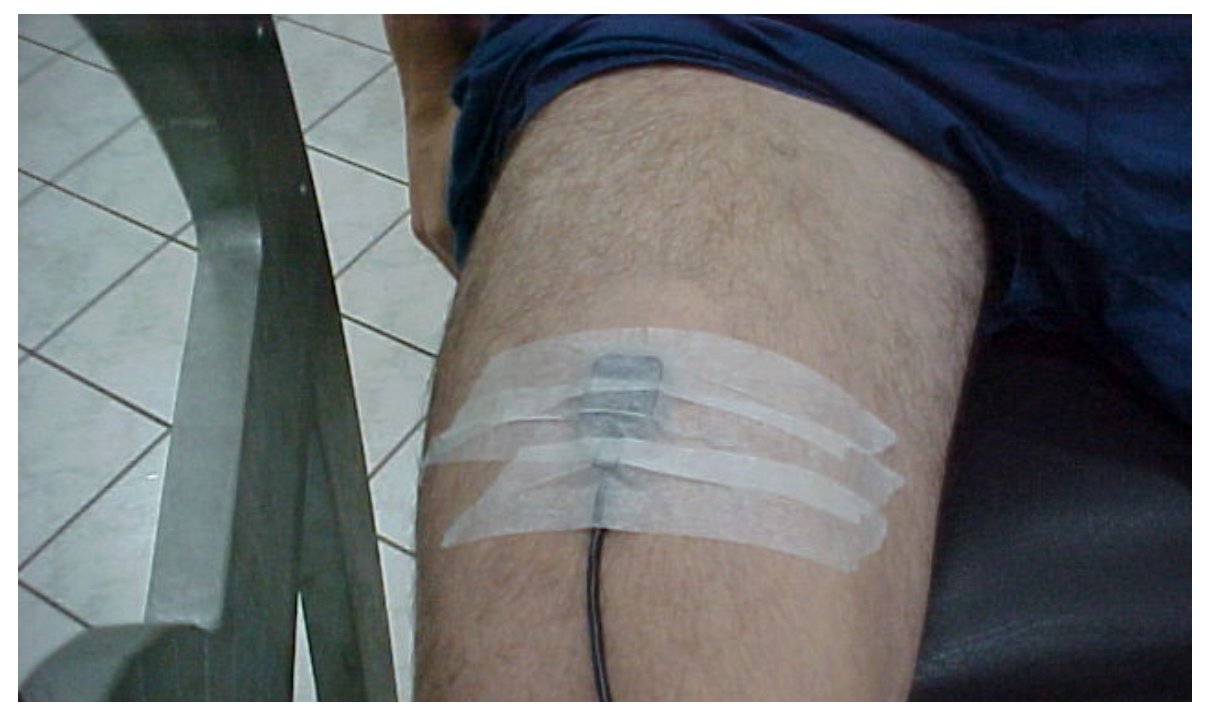

Figura 27 - Eletrodo fixado com fita adesiva sobre o músculo reto femoral, o eletrodo de referência foi fixado no maléolo do membro contralateral.

\section{5- Instrumentação}

Para a coleta do sinal de tensão da corda elástica durante o seu estiramento foi utilizada uma célula de carga do tipo strain-gage, marca Kratos modelo MM com capacidade de $1000 \mathrm{~N}$ (figura 28). No sistema de tração foi incluido um eletrogoniometro constituído por um potenciômetro linear de precisão multivoltas de 10 $\mathrm{K} \Omega$, que tem por objetivo registrar a posição angular da roda (figura 29). No sistema de tração foi incluído também outro potenciômetro do mesmo tipo citado anteriormente, com o objetivo de fazer a leitura da velocidade tangencial do sistema em tempo real. Esta informação permitiu aos sujeitos realizar o controle da velocidade das fases do ciclo de exercício via feedback.

Para a aquisição do sinal de EMG foi utilizado um eletrodo bipolar ativo de superfície, constituído de duas barras de $\mathrm{Ag} / \mathrm{AgCl}$ de $10 \mathrm{~mm}$ de comprimento por $1 \mathrm{~mm}$ de largura cada, posicionadas paralelamente e separadas entre si em $10 \mathrm{~mm}$, sendo encapsuladas num molde retangular de poliuretano (figura 30). 
O eletrodo possui no encapsulamento, um circuito pré amplificador com ganho de 20 vezes, CMRR (Common mode rejection ratio) maior que $80 \mathrm{~dB}$ e impedância de $1012 \Omega$.

Os sinais provenientes da célula de carga, do eletrogoniômetro e do eletrodo foram captados em um módulo condicionador de sinais, modelo MCS 1000 (figura 31), da marca Lynx. Dois canais foram configurados para receber os sinais da célula de carga e do eletrogoniometro. Outro canal foi calibrado para receber os sinais de EMG.

Todos os sinais analógicos foram digitalizados através de uma placa de conversão de sinal (A/D) modelo CAD 12/36 (Lynx), de 12 bits de resolução. Para a aquisição e armazenamento em arquivos de dados dos sinais digitalizados utilizou-se o software Aqdados (Lynx) versão 4.0.

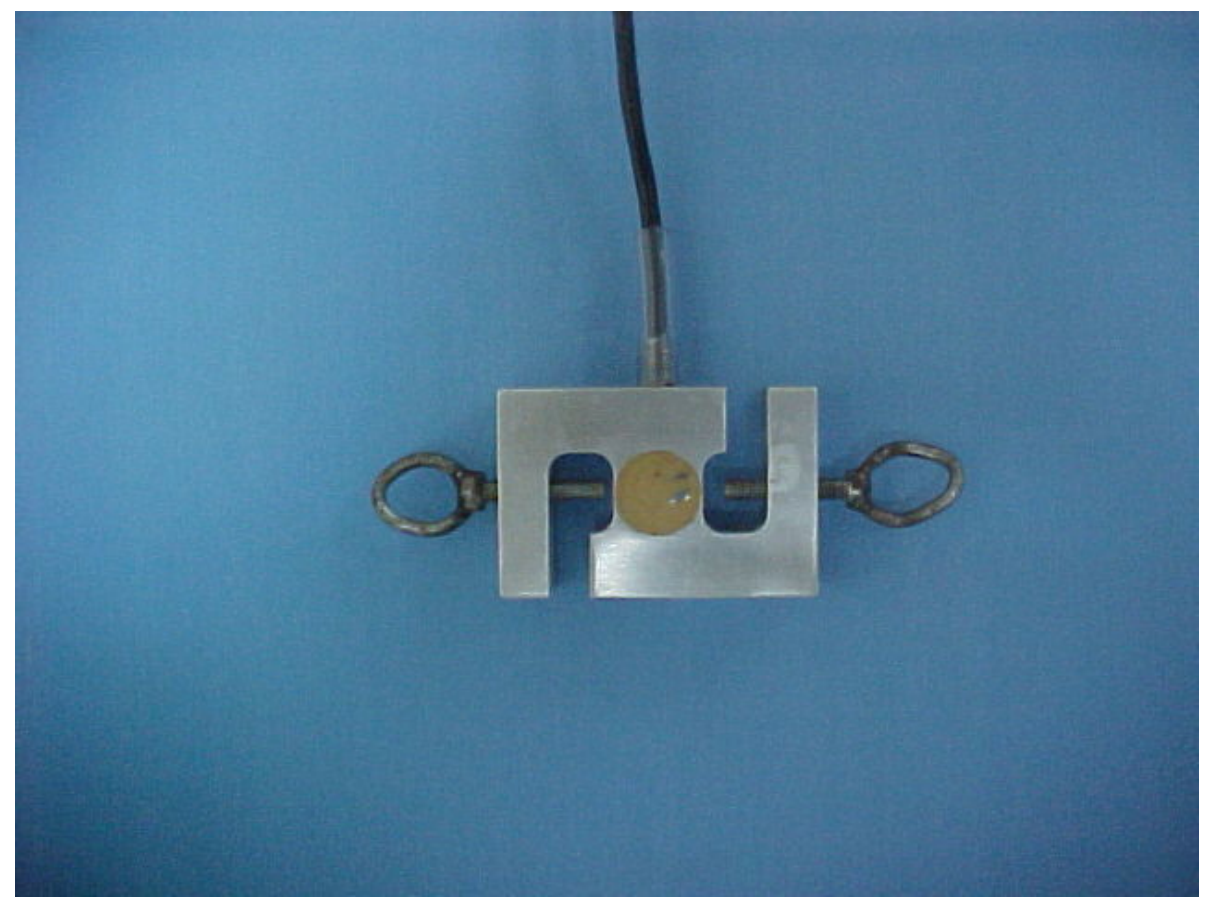

Figura 28. Célula de carga. 


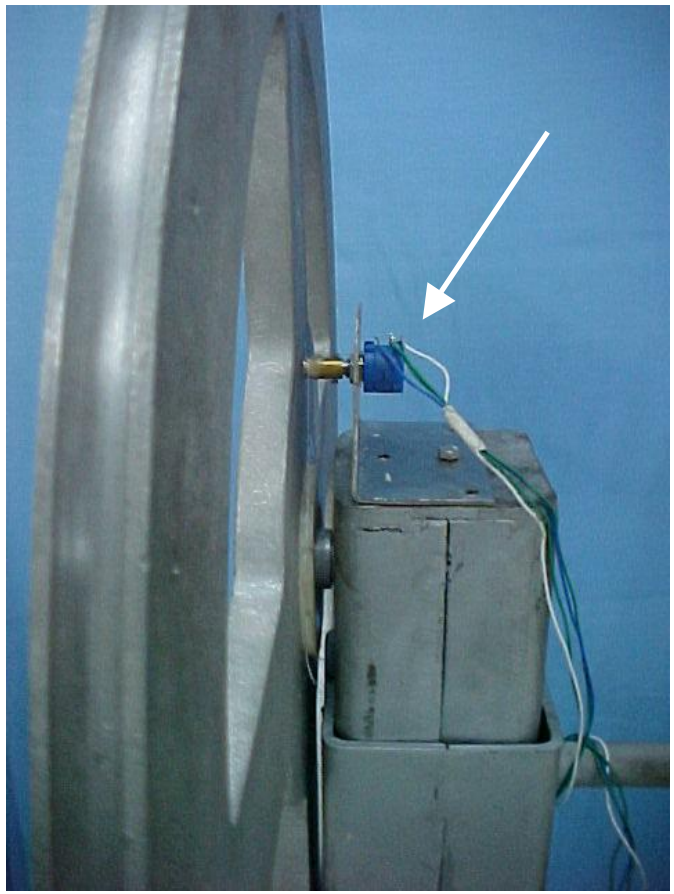

Figura 29. Eletrogoniometro (seta).

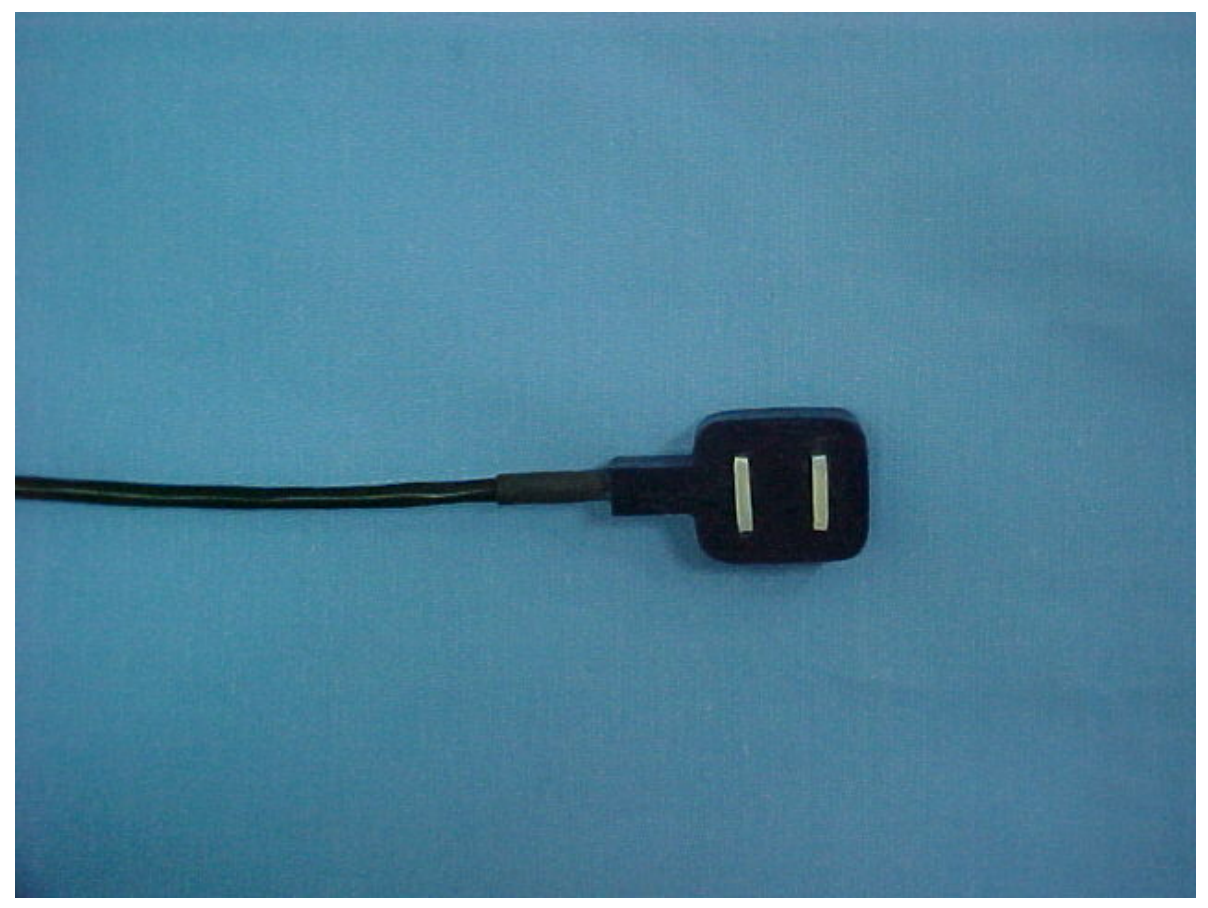

Figura 30. Eletrodo ativo de superfície. 


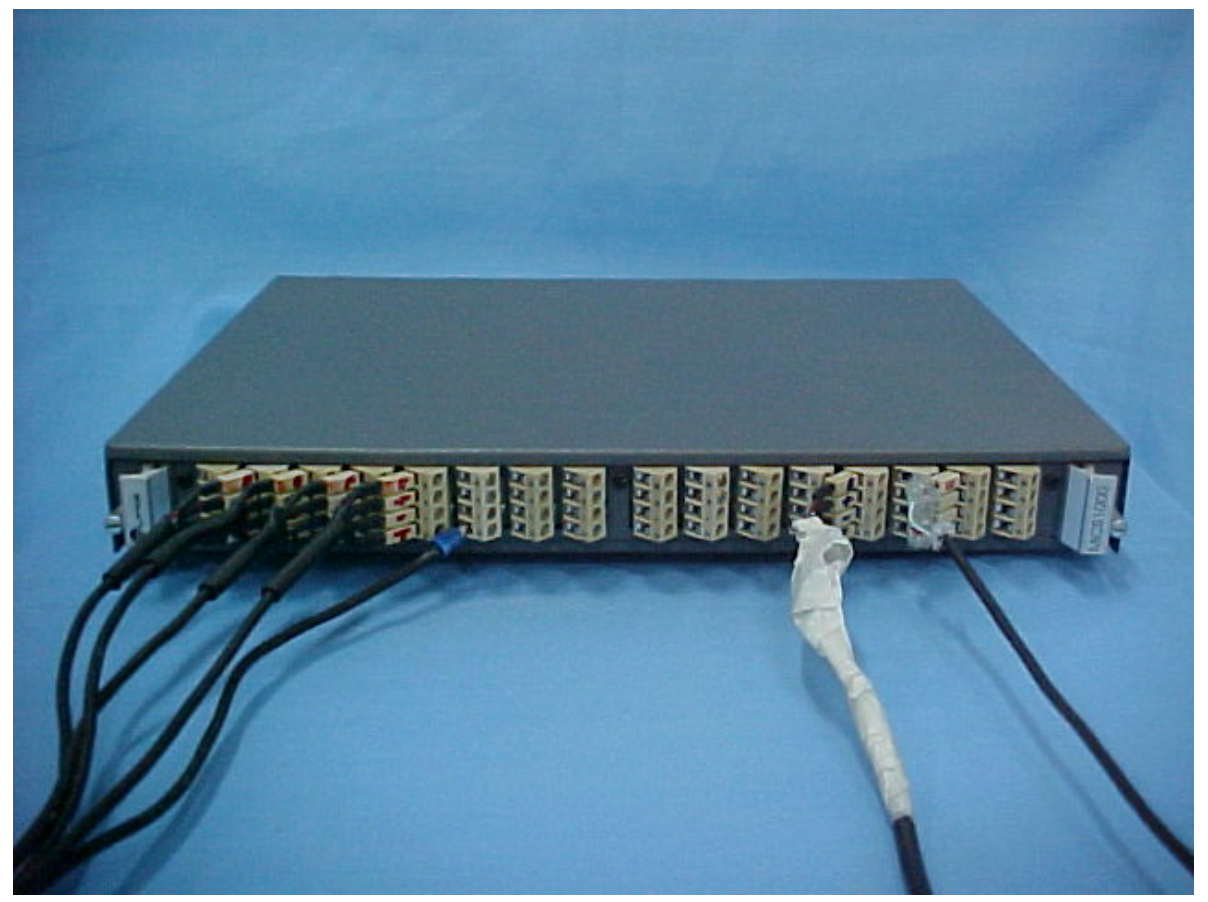

Figura 31. Condicionador de sinais.

\section{6- Tratamento dos dados.}

\subsection{1- Tratamento e aplicação dos dados dinâmicos e cinemáticos.}

Os dados provenientes da célula de carga e do eletrogoniometro, referentes aos dez ciclos realizados por cada sujeito, descrito no item 3.4.2, foram tratados conforme os seguintes passos:

a) aplicou-se um filtro (FFT) digital com freqüência de corte de $5 \mathrm{~Hz}$;

b) obteve-se a média e o desvio padrão dos dados referentes aos dez ciclos de cada sujeito;

c) os dados resultantes foram normalizadas na base de tempo, em função do tempo de duração de um ciclo em porcentagem (0-100\%).

Para atender a condição de equilíbrio proposta nas equações dinâmicas apresentadas anteriormente deve-se contemplar as áreas do movimento onde se estabelece a maior constância da velocidade. Ao considerar nas equações dinâmicas que 
o movimento é realizado em velocidade constante, automaticamente assume-se um erro experimental que é diretamente proporcional a variação da velocidade do movimento durante o experimento. Isto devido ao fato de que o sistema de exercício não dispõe de um dispositivo de controle da velocidade, ficando a cargo do sujeito este controle.

Adotou-se uma solução objetivando minimizar este erro, que consiste na seleção dos trechos de dados, dinâmicos, que apresentam maior constância na velocidade, para posterior aplicação em nossas equações. Para isso utilizou-se os dados cinemáticos fornecidos pelo eletrogoniometro (figura 32) e através da derivação da curva posição angular em função do tempo absoluto, obteve-se a velocidade angular do sistema para cada ciclo.

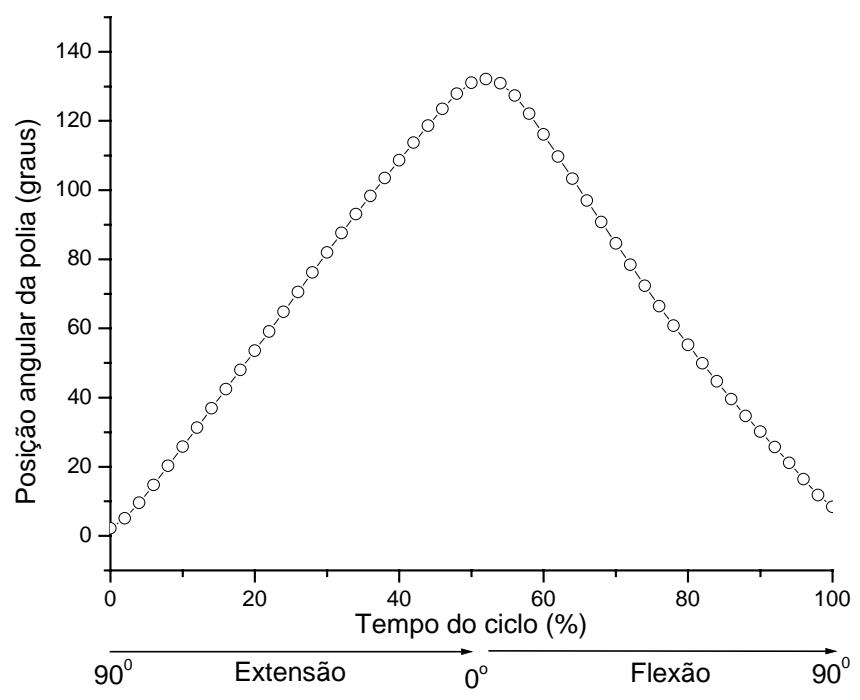

Figura 32. Posição angular, média de dez ciclos, da polia do sistema de exercício ( $\theta)$ em função do tempo normalizado do ciclo. 


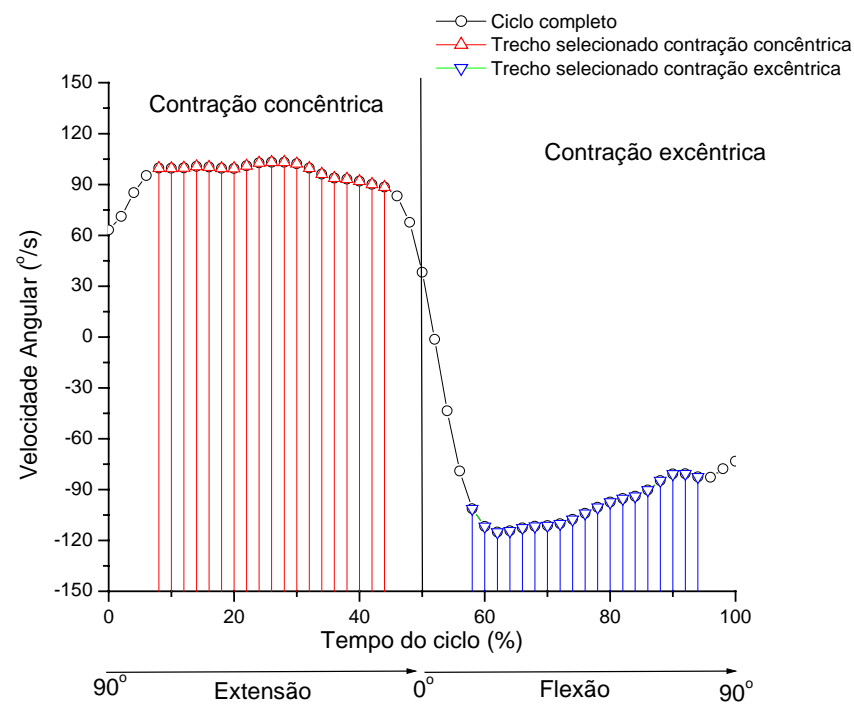

Figura 33. Velocidade angular, média de dez ciclos, obtida através da derivação da curva da figura 32.

As figuras 32 e 33 apresentam respectivamente um exemplo da posição angular da polia do sistema de tração em função do tempo normalizado e a velocidade angular média nos 10 ciclos realizados por um dos voluntários.

Observa-se na figura 33 os trechos com velocidade aproximadamente constante da contração concêntrica e da contração excêntrica selecionados para serem aplicados nas equações. Com base nestas observações propôs-se uma padronização para a seleção dos trechos de dados a serem aplicados nas equações, que seguiu o seguinte critério:

a) contração concêntrica - 10 a $40 \%$ do ciclo; ou $18^{\circ}$ a $72^{\circ}$ de flexão;

b) contração excêntrica - 60 a $90 \%$ do ciclo ; ou $72^{\circ}$ a $18^{\circ}$ de extensão.

Após o tratamento dos dados dinâmicos e cinemáticos os mesmos foram aplicados nas equações conforme o fluxograma apresentado na figura 34 . 


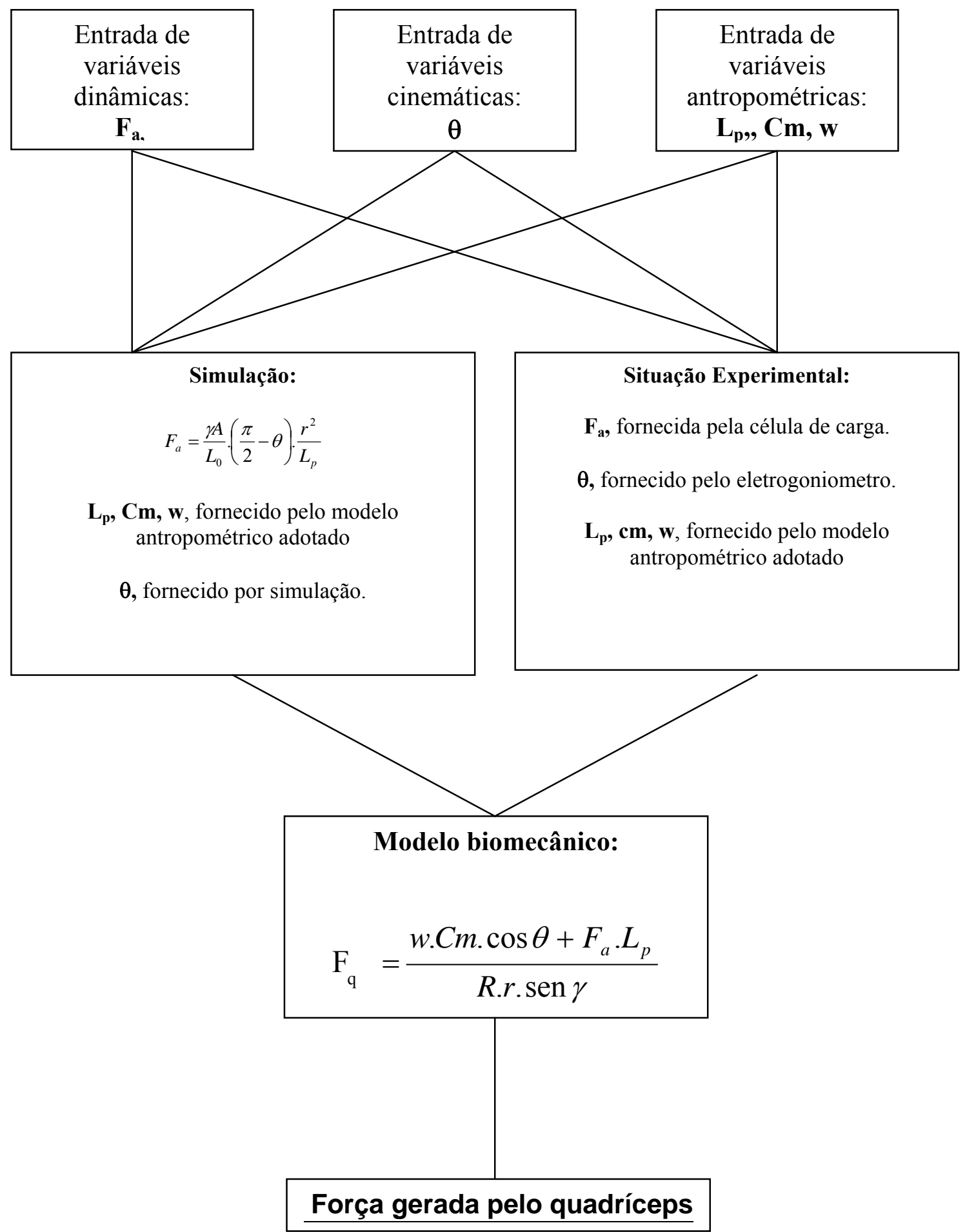

Figura 34. Fluxograma demonstrando a aplicação dos dados para a obtenção dos resultados experimentais e simulados. 


\subsection{2-Tratamento dos sinais EMG.}

Após a execução do protocolo descrito no item 1.4.2. os sinais contidos no tempo de exercício, desde o início até a plena fadiga, de cada voluntário foram divididos em 5 partes. A primeira parte representa o início do exercício (sem fadiga) e a última o fim, quando o sujeito apresenta a falência muscular, as outras três partes são intermediárias. Após esta etapa os sinais foram submetidos a dois tipos de análise, ambas realizadas através de rotinas específicas desenvolvidas no software MatLab ver 6.0 .

\subsubsection{1- Análise no domínio da freqüência do sinal de EMG.}

A analise no domínio da freqüência de um sinal mioelétrico (EMG) está de certa forma bem estabelecida dentro da literatura cientifica para sua aplicação em sinais gerados durante uma contração isométrica (figura 35) (DeLUCA, 1997, 1985, LINDSTRON et al., 1977; BIGLAND-RICHIE, 1979; MORITANI et al., 1982).

Para sinais provenientes de contrações dinâmicas existe certa controvérsia no que diz respeito a este tipo de análise. Esta controvérsia remete ao método utilizado para se destinguir, durante uma contração isotônica (figura 36), o tempo de contração efetiva e o de "repouso" da contração (figura 37) (KOMI, 1979). As descontinuidades que o sinal de EMG, proveniente de contrações isotônicas, apresentam entre uma contração e outra é um fator limitante para a aplicação de ferramentas matemáticas destinadas a obtenção do espectro de freqüência do sinal.

Para a observação fidedigna dos parâmetros espectrais, freqüência mèdia (Fmed) e mediana (FM), tem-se que a aplicação do algoritmo da FFT (Fast Fourier Transform) deve ser feita apenas à janelas dos sinais que realmente representam a contração efetiva do músculo (PEREIRA \& AZEVEDO, 2002).

Neste estudo, pelo fato de se trabalhar com contrações isotônicas, adotou-se a seguinte metodologia para a obtenção do espectro de freqüência do sinal de EMG:

(a) Selecionou-se sete traçados mioélétricos de cada um dos cinco trechos em que do tempo total de exercício foi inicialmente dividido.

(b) De cada traçado selecionado uma janela central de 400ms foi extraída. 
(c) os 35 traçados selecionados foram seqüenciados como demonstrado na figura 38 , totalizando 35 segundos de sinal.

Portanto o sinal mostrado na figura 38 representa a evolução temporal, desde o início do exercício até o seu final.

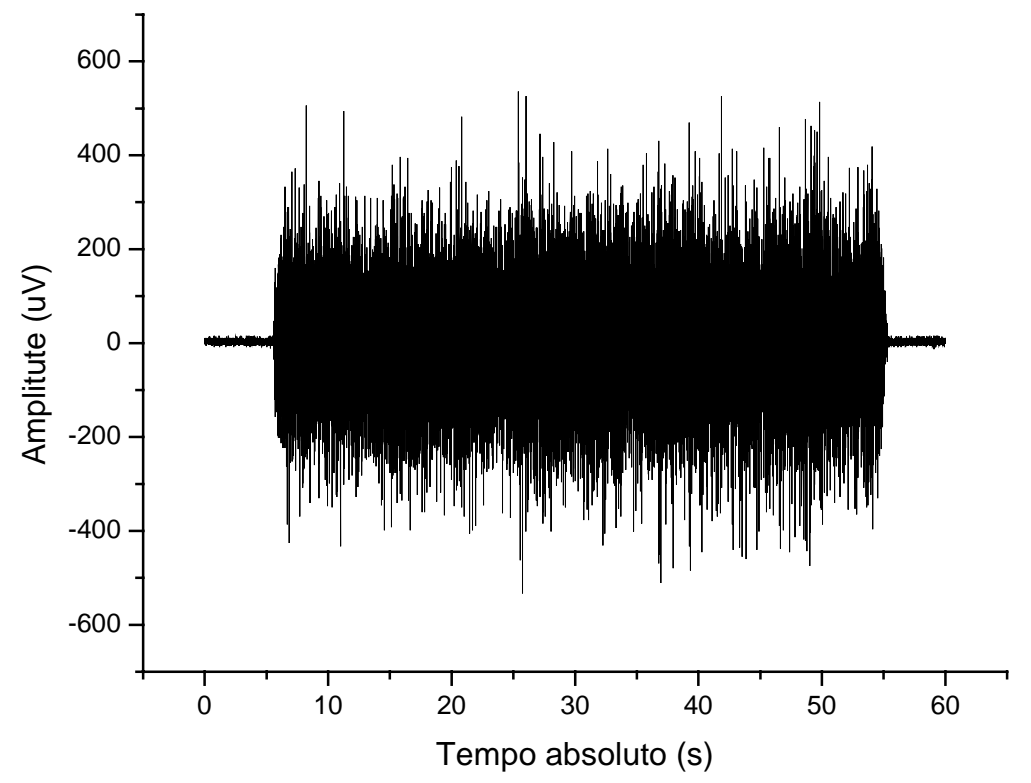

Figura 35. Exemplo de traçado mioelétrico originado de uma contração múscular isométrica. 


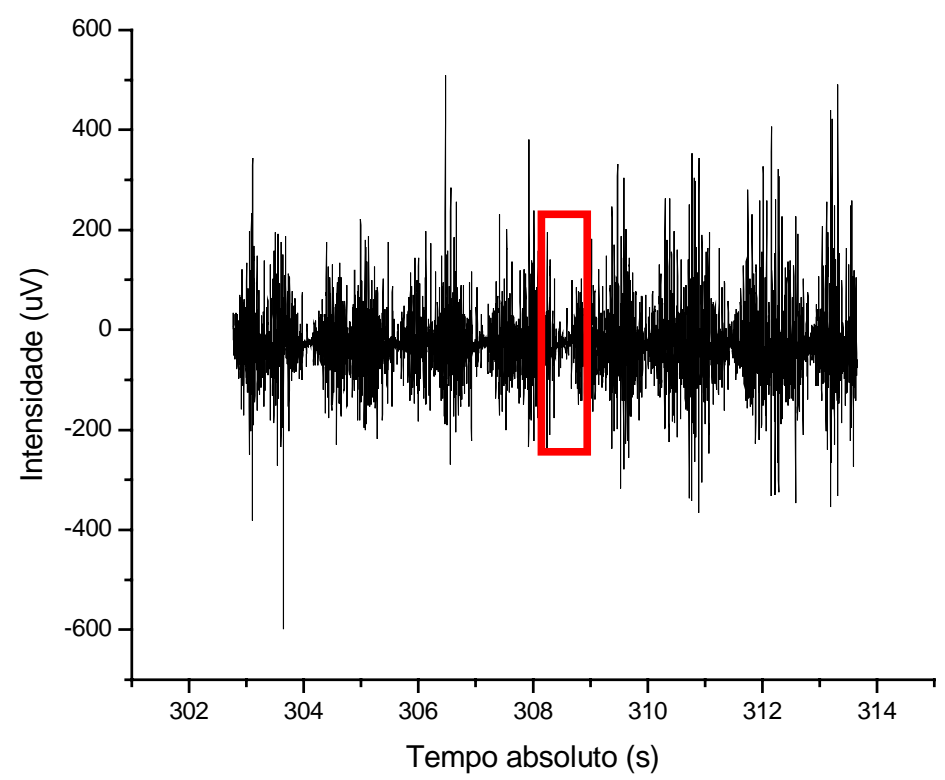

Figura 36. Exemplo de um sinal mioelétrico originado de varias contrações dinâmicas. No detalhe, observa-se uma região de descontinuidade do sinal.

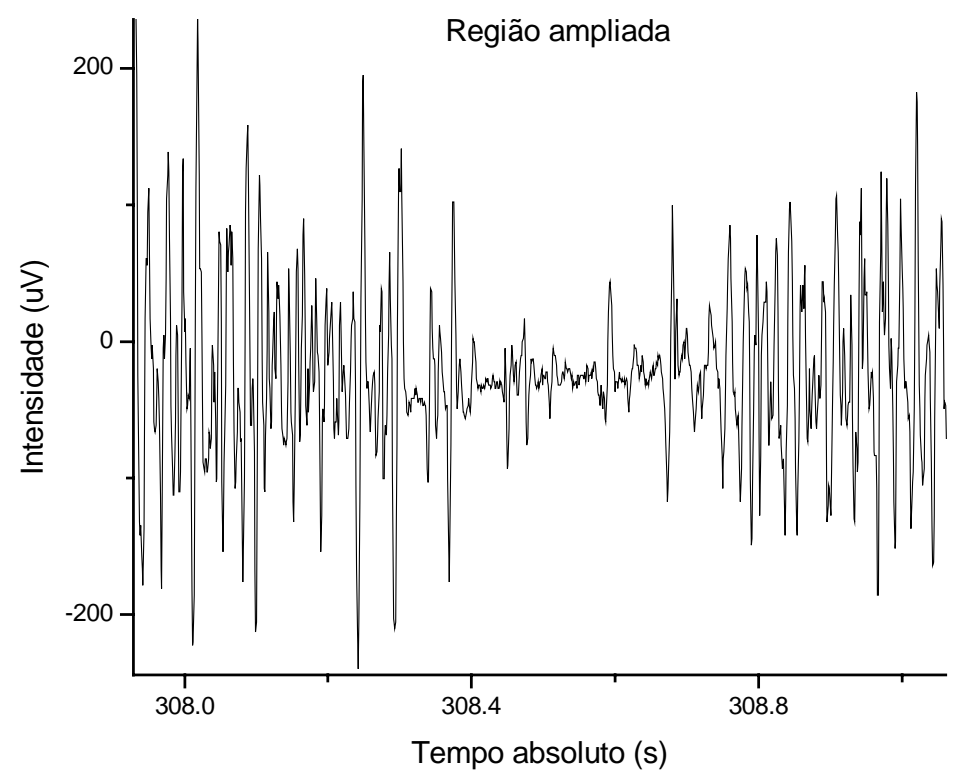

Figura 37. Região vermelha ampliada observa-se o trecho correspondente intervalo entre as contrações. 


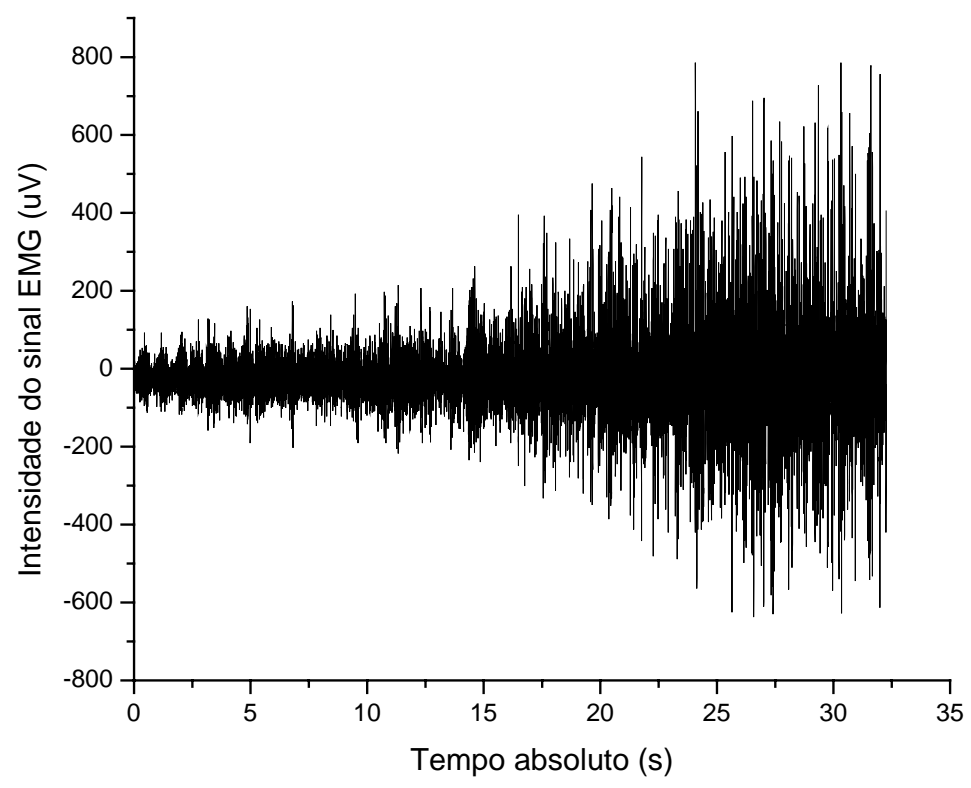

Figura 38. Exemplo de sequenciamento dos traçados mioelétricos, coletados de forma dinâmica, totalizando 35 segundos.

Ao traçado seqüenciado foi aplicado um filtro digital passa-alta Chebyshev tipo 1 com banda de corte de $20 \mathrm{~Hz}$. O tempo absoluto foi normalizado em função de 0 a $100 \%$ do tempo de exercício. Após a filtragem e a normalização do tempo, foi aplicado o algoritmo FFT para a obtenção da distribuição espectral do sinal em janelas de 1 segundo ( $\mathrm{n}=1000)$ do traçado seqüenciado (figura 39).

Após a obtenção dos espectros de freqüência dos sinais contidos nas janelas, calculou-se os valores da Fmed e FM, para cada janela,utilizando-se a função de distribuição espectral (SDF). A SDF (figura 40) pode ser definida como a integral normalizada do espectro de amplitude do sinal de EMG e representa uma ferramenta de análise complementar pois permite uma visualização da distribuição acumulada do sinal em função da freqüência (BROMAN et al., 1985).

Os valores da Fmed e FM foram normalizados em função da Fmed e FM calculadas na primeira janela, para cada sujeito. Após a normalização foram obtidos os valores médios e os desvios padrão dos parâmetros espectrais, a cada intervalo de $10 \%$ do tempo de exercício. 


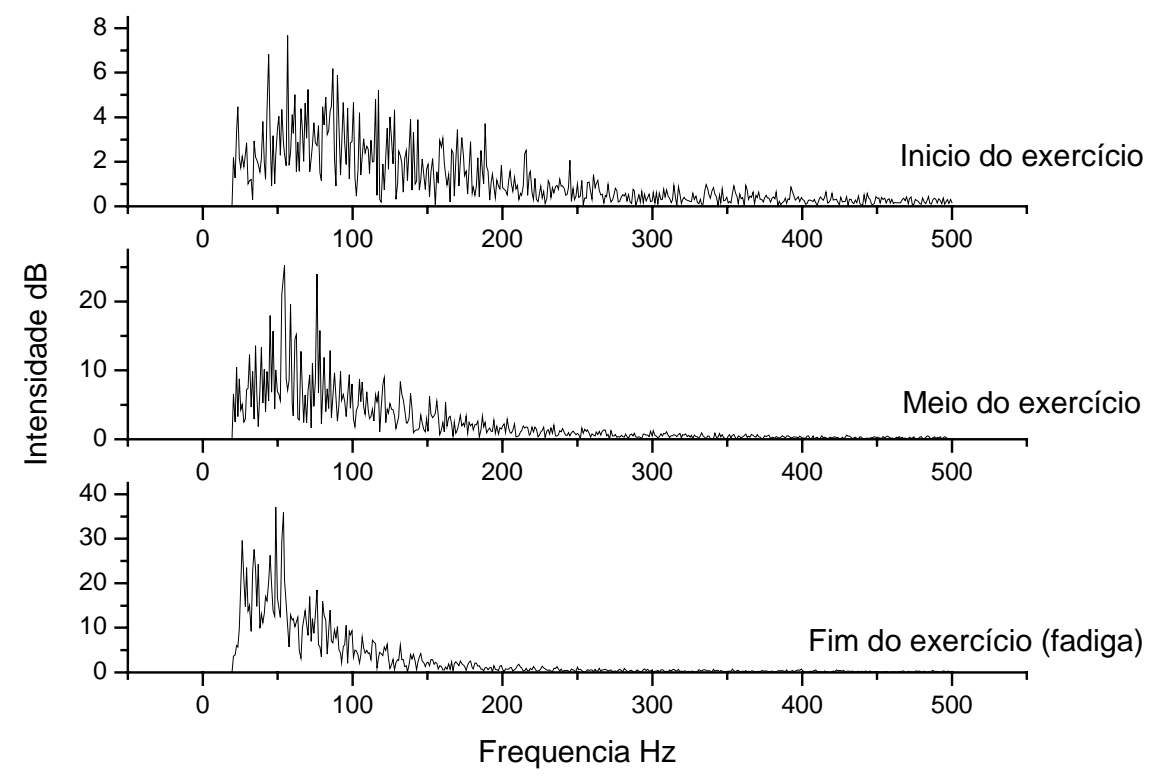

Figura 39. Exemplos de espectros de freqüência de janelas de 1 segundo do sinal mioelétrico apresentado na figura 38 .

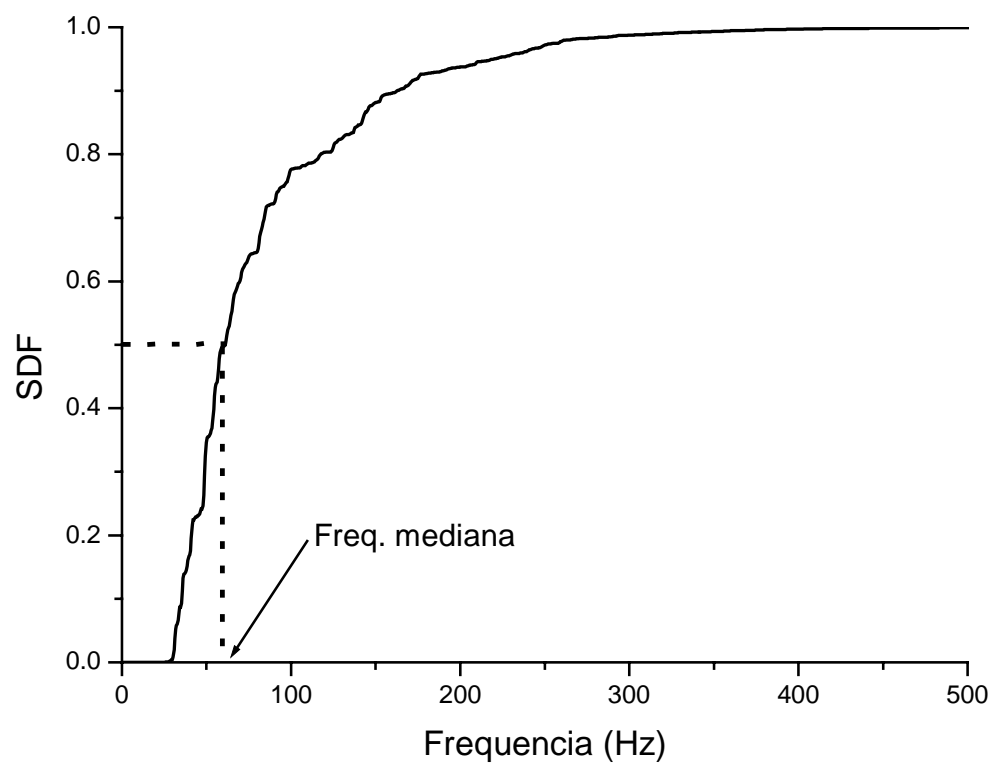

Figura 40. Exemplo da função de distribuição espectral (SDF) para o espectro de amplitude do sinal EMG onde $F_{1}$ representa a freqüência mediana da janela. 


\subsubsection{2-Análise no domínio do tempo do sinal de EMG.}

Do primeiro trecho do sinal aquele, referente ao inicio do exercício, quando ainda não havia fadiga, foram selecionados dez traçados de ciclos completos (contração concêntrica e contração excêntrica) para cada sujeito.

Os traçados eletromiográficos foram tratados conforme descrito por WINTER (1990), cujo processamento consistiu nas seguintes etapas: i) retificação total do sinal também conhecido como retificação de onda completa, que consiste na obtenção do valor absoluto do traçado eletromiográfico de forma que todos os sinais negativos são invertidos, passando desta forma, a possuir apenas sinais positivos; ii) normalização da amplitude do sinal - procedimento que consiste em submeter os valores do sinal eletromiográfico retificado ao valor de referência, e que seja comum a todos os sinais, de forma a permitir comparações entre os sujeitos, músculos, etc.; e que neste caso foi empregado a média do sinal referente ao primeiro trecho selecionado; iii) envoltório linear - obtido a partir do traçado retificado, fazendo uso de um filtro (passa-baixa) digital com freqüência de corte de $5 \mathrm{~Hz}$; iv) normalização da base de tempo procedimento que tem como objetivo normalizar o tempo de atividade dos diferentes trechos selecionados, onde o tempo é convertido em porcentagem do ciclo de contração (0 a 100\% do ciclo). A figura 41 exemplifica os passos descritos acima.

Após o tratamento descrito acima foram selecionados os sinais EMG contidos entre 10 e $40 \%$ da contração concêntrica e 60 e $90 \%$ da contração excêntrica. Esta seleção se fez necessária para possibilitar a correlação entre o padrão de ativação do músculo reto e da força gerada pelo quadríceps durante o exercício, tendo em vista que os resultados de força sofreram o mesmo processo de seleção (item 3.6.1).

Com objetivo de se testar a correlações entre o sinal EMG e a força gerada pelo músculo durante o exercício, calculou-se o somatório acumulativo dos sinais representativos da contração concêntrica e excêntrica (MORITANI, 1978; LIPPOLD \& EDWARDS, 1956; LIPPOLD, 1952). Para testar a correlação entre os dados foi aplicado o teste de correlação de Spearman. 


\section{Etapas para o tratamento do sinal no domínio do tempo.}

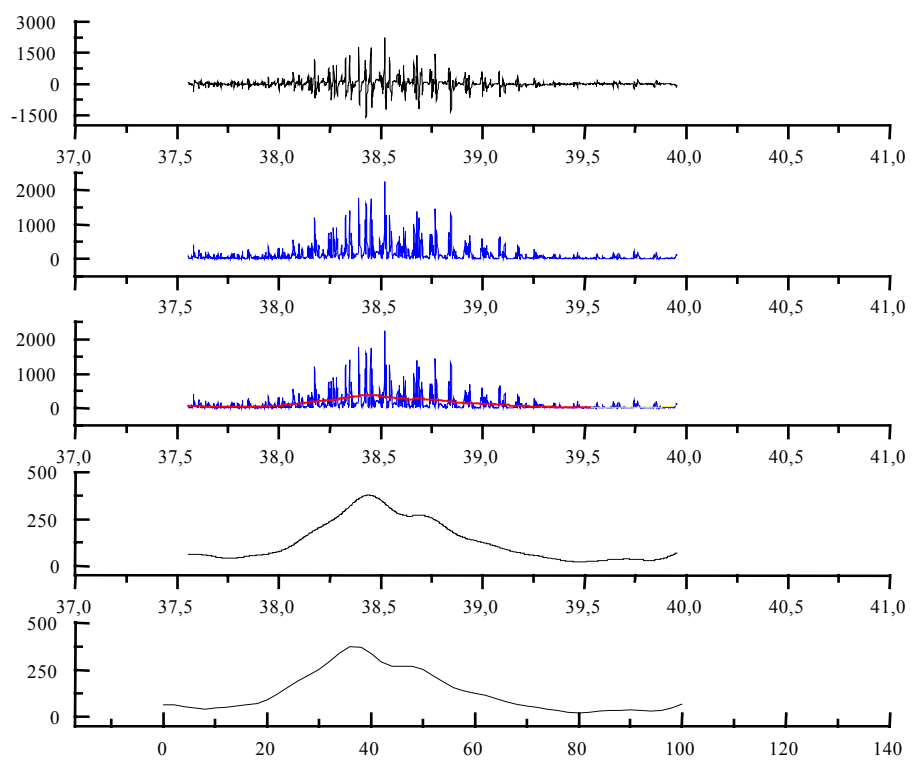

Sinal Bruto.

Sinal Bruto retificado.

Envoltório linear (linha vermelha).

Envoltório linear na base de tempo absoluto (s).

Envoltório linear normalizado na base de tempo (\%).

Figura 41. Exemplo da seqüência do tratamento do sinal de EMG no domínio do tempo. 
4. RESULTADOS 


\section{4- RESULTADOS}

\section{1 - Força gerada pelo quadríceps femoral em exercícios simulados.}

Sendo a proposta fundamental do presente estudo, demonstrar o comportamento da força gerada pelo músculo quadríceps durante o exercício com uma resistência elástica, a situação de exercício simulada torna-se uma fonte de informações indispensável para tal propósito.

A partir das simulações pode-se observar o comportamento do músculo em função de diferentes variáveis, principalmente da força aplicada $F_{a}$. No entanto é importante lembrar que os resultados obtidos através das simulações não correspondem integralmente à realidade, pois nas simulações adotou-se condições ideais de exercício como, por exemplo, um tubo de látex ideal e a ausência de variação na velocidade angular durante o movimento.

Inicialmente buscou-se identificar como o músculo se comporta no sentido de, durante o exercício, vencer o próprio peso da perna, a força aplicada $F_{a}$ isolada e a situação próxima da real onde estas duas sobrecargas são somadas. Para a realização destas simulações considerou-se um tubo de látex com coeficiente de elasticidade e comprimento inicial iguais aos medidos nos tubos que foram utilizados na situação experimental, $\gamma \mathrm{A}=11 \mathrm{~N}$ e $\mathrm{L}_{0}=0,6 \mathrm{~m}$ (figuras 42 ). 

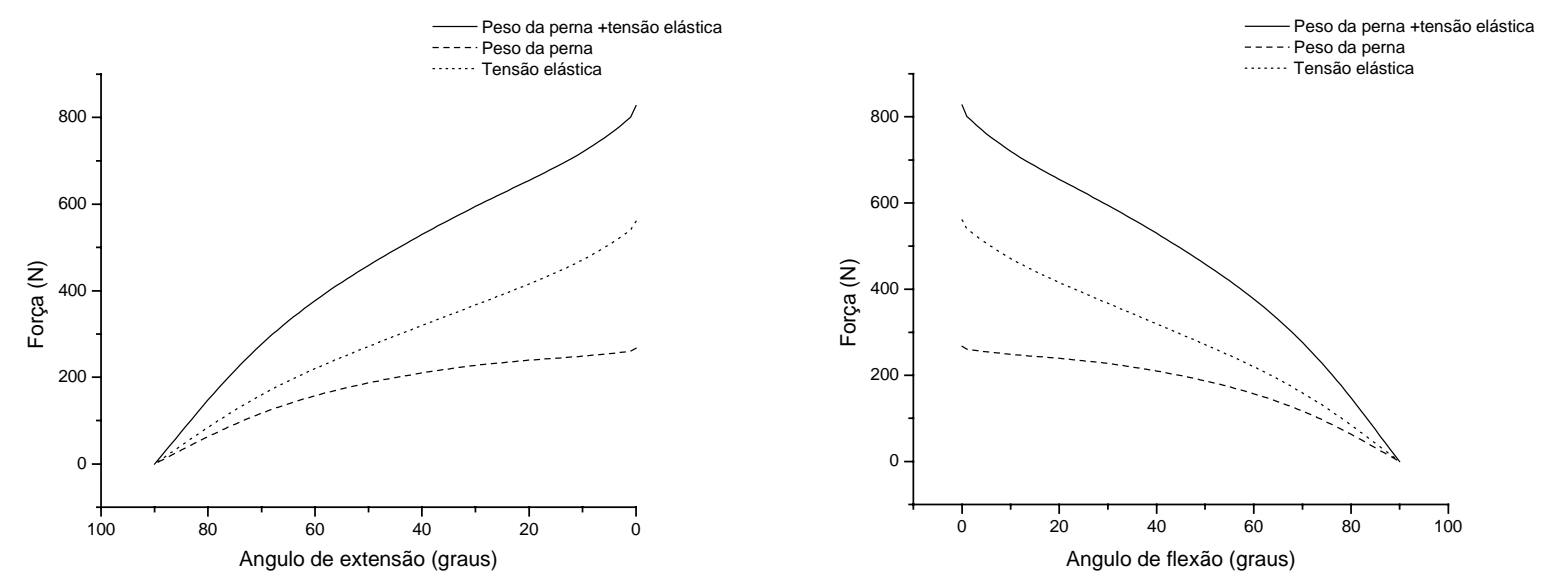

Figura 42. Força gerada pelo músculo quadríceps para vencer o peso da própria perna, a força aplicada $F_{a}$ isolada e a soma das duas cargas.

A aplicação de um tubo com as características citadas acima, em uma situação experimental não é viável. A sobrecarga que a corda oferece a um sujeito saudável, como os submetidos ao exercício experimental, é praticamente desprezível para um músculo com a capacidade de geração de força como o quadríceps.

Realizou-se simulações com uma força aplicada de valor máximo igual a 110N. $\mathrm{O}$ incremento da força aplicada foi definido como o valor aproximado de força que quatro tubos elásticos de $\gamma \mathrm{A}=11 \mathrm{~N}$ e $\mathrm{L}_{0}=0,6 \mathrm{~m}$ geram quando dispostos em paralelo, formando um "cabo". Este parâmetro foi simulado e aplicado ao modelo, obtendo-se as curvas demonstradas na figura 43.

Observa-se em ambas as figuras que as curvas de força gerada pelo músculo não alteram o seu padrão crescente, em função do ângulo de flexão do joelho $(\theta)$, mesmo com o incremento da força aplica $\left(\mathrm{F}_{\mathrm{a}}\right)$ pelo tubo elástico durante o exercício simulado. 

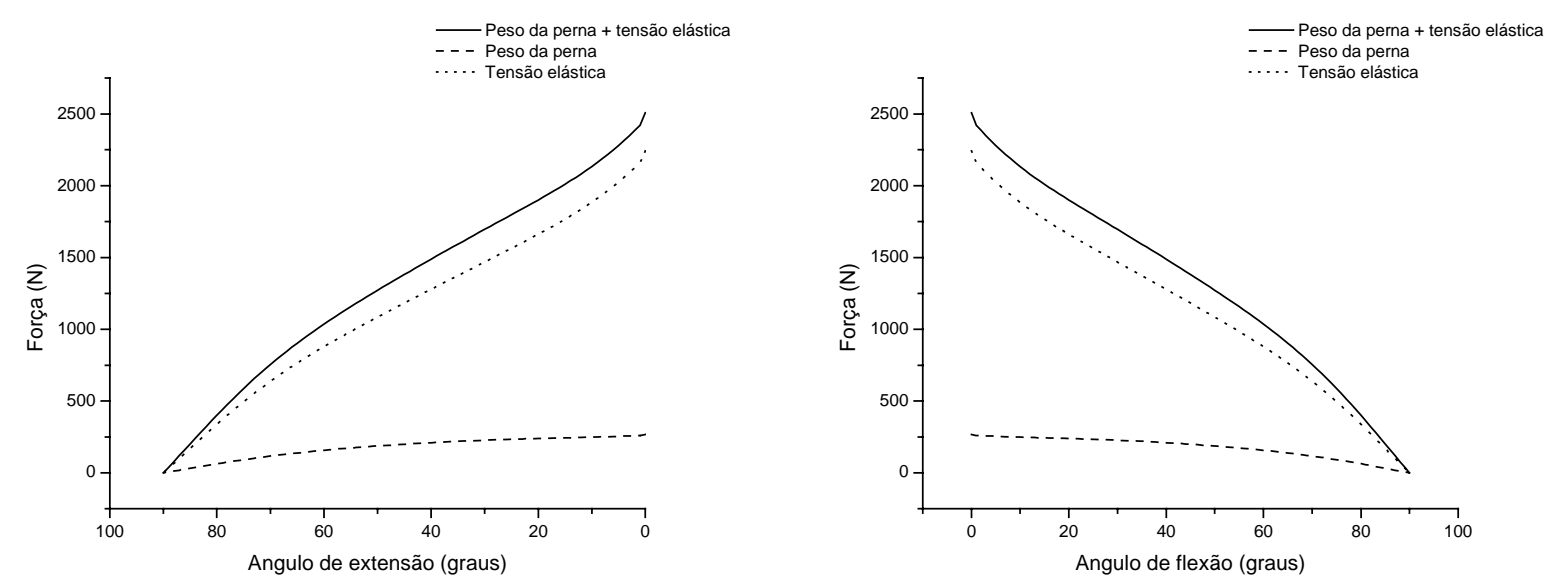

Figura 43. Força gerada pelo músculo quadríceps para vencer o peso da própria perna, a força aplicada $F_{a}$ isolada e a soma das duas cargas.

Observa-se também que na primeira situação (figura 42) o exercício com a corda elástica pouco diferencia daquele sem a aplicação de força externa, enquanto que na figura 43 mostra-se a solicitação de intensa geração de força do músculo.

A figura 44 e 45 demonstra uma outra situação onde os parâmetros das cordas, que formam o "cabo" elástico considerado nestas situações simuladas de exercícios, são alterados. Na primeira situação (figura 44) são considerados três valores diferentes de fator de elasticidade $(\gamma \mathrm{A})$ dos tubos com $\mathrm{L}_{0}=0,6 \mathrm{~m} ; \gamma \mathrm{A}=11 \mathrm{~N} ; \gamma \mathrm{A}=15$ e $\gamma \mathrm{A}=20 \mathrm{~N}$. Na segunda situação (figura 45) são considerados três valores diferentes de comprimento inicial dos tubos $\left(\mathrm{L}_{0}\right) \operatorname{com} \gamma \mathrm{A}=11 \mathrm{~N} ; \mathrm{L}_{0}=0,6 \mathrm{~m} ; \mathrm{L}_{0}=1 \mathrm{~m} \mathrm{eL} \mathrm{L}_{0}=0,2 \mathrm{~m}$.

È importante deixar claro neste ponto que o comprimento inicial de tubos abaixo de $0,5 \mathrm{~m}$, acoplados no sistema de tração, não satisfazem a condição experimental predeterminada no item 3.3.2 do capítulo 3, que preconiza que os tubos não devem ser estirados alem de suas áreas de deformação elástica. Outro ponto é que valores de coeficiente de elasticidade maiores que $25 \mathrm{~N}$ de tubos com $\mathrm{L}_{0}=0,6 \mathrm{~m}$, caracterizam um material elástico extremamente resistente a esforços de tensão.

Propositalmente as simulações apresentadas nas figuras 44 e 45 contemplam uma situação de exercício simulada onde ambos os parâmetros citados acima são extrapolados. Obteve-se então, valores de força gerada pelo quadríceps completamente irreais, que sugerem que em uma situação experimental, o sujeito submetido ao exercício não conseguirá completar o arco completo de movimento, como conseqüência do excesso de sobrecarga. 

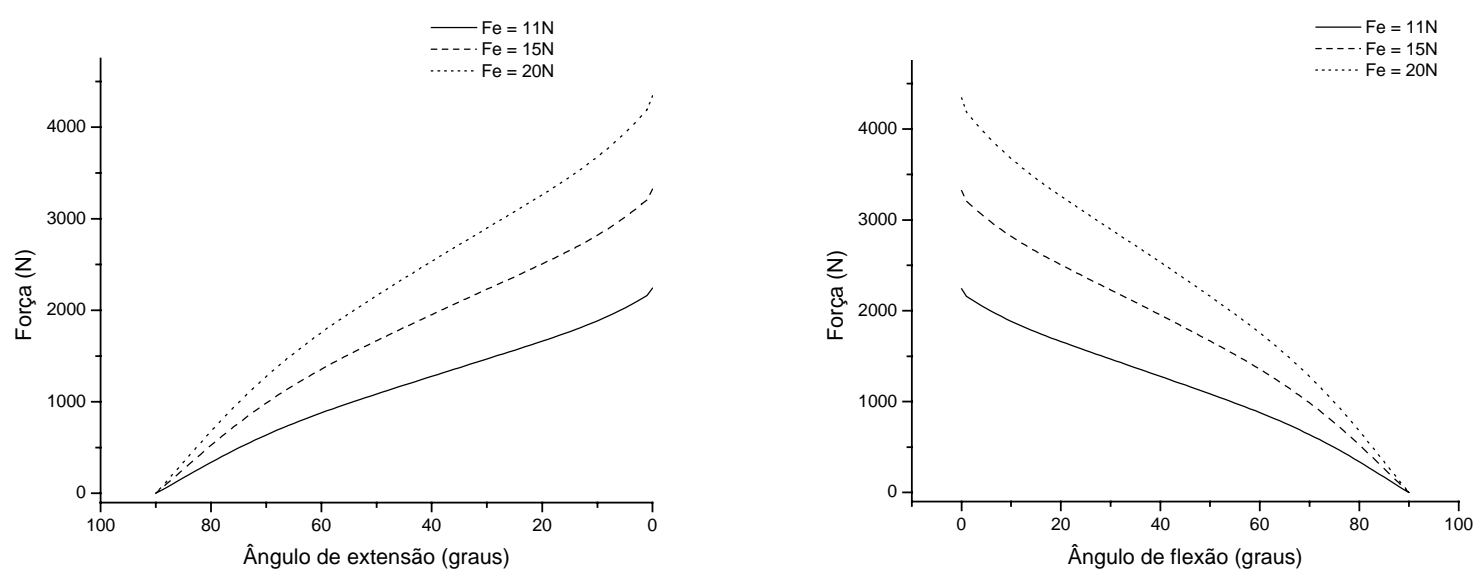

Figura 44. Força gerada pelo músculo quadríceps quando submetido ao exercício com tubos elásticos que apresentam diferentes fatores de elasticidade $(\gamma \mathbf{A})$.
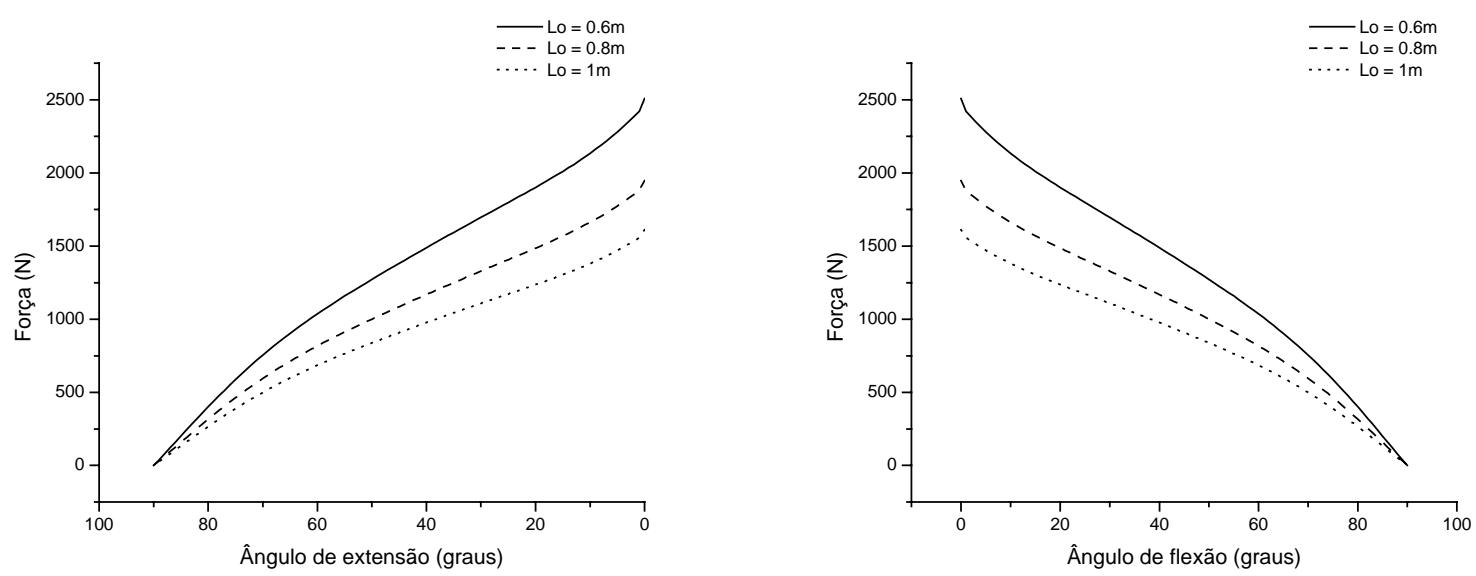

Figura 45. Força gerada pelo músculo quadríceps quando submetido ao exercício com tubos elásticos que apresentam diferentes comprimentos iniciais $\left(\mathrm{L}_{0}\right)$.

Com relação aos outros parâmetros dos tubos aplicados nas simulações apresentadas nas figuras 41 e 42, observa-se um comportamento normal do músculo quadríceps quanto a geração de força em função das alterações nos parâmetros dos tubos. È esperado que quanto menor o $\mathrm{L}_{0}$ e maior o $\gamma \mathrm{A}$ dos tubos a força resultante gerada pelo músculo seja maior. Fato demonstrado nas curvas de força apresentadas nas figura 44 e 45. 


\section{2 - Força gerada pelo quadríceps femoral em exercício experimental.}

Após a aquisição dos dados dinâmicos e cinemáticos, durante os exercícios a que os sujeitos foram submetidos conforme o item 3.4.2 do capitulo 3, os mesmos foram aplicados ao modelo biomecânico proposto. Obteve-se a curva da força média gerada pelo músculo quadríceps dos sujeitos $(\mathrm{n}=5)$ submetidos ao exercício no sistema mecânico. A figura 46 apresenta a curva para a contração concêntrica e a figura 47 para a contração excêntrica.

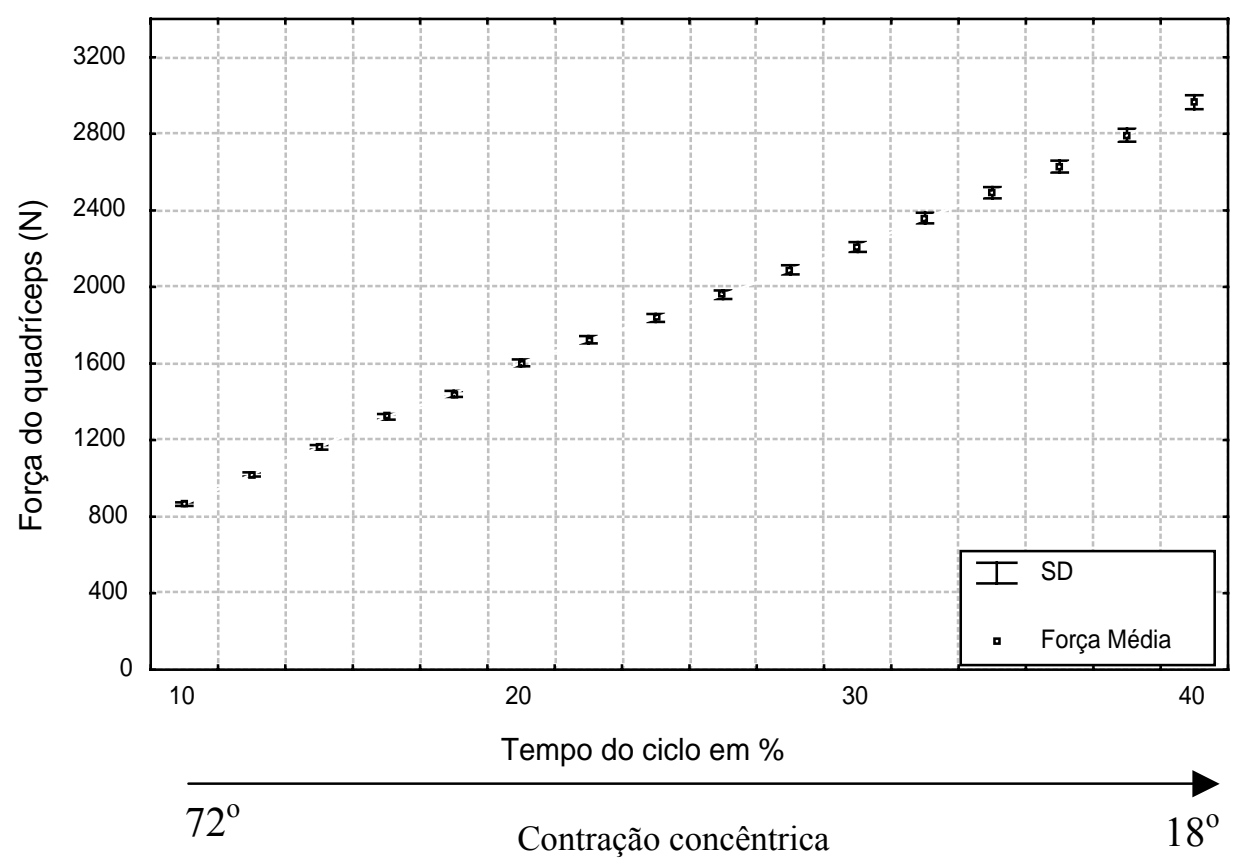

Figura 46. Força média gerada pelo músculo quadríceps femoral e o desvio padrão dos cinco sujeitos submetidos ao exercício com uma resistência elástica (contração excêntrica). 


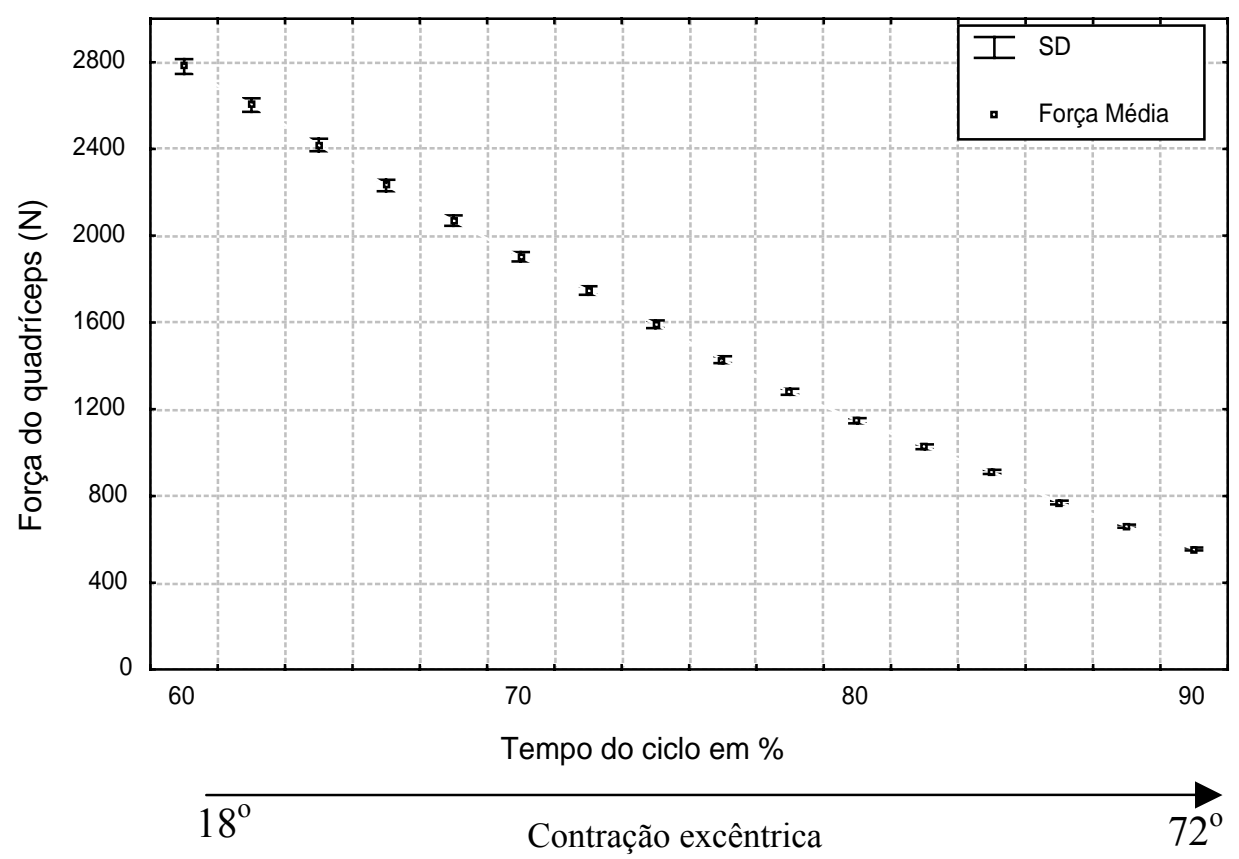

Figura 47. Força média gerada pelo músculo quadríceps femoral e o desvio padrão dos cinco sujeitos submetidos ao exercício com uma resistência elástica (contração excêntrica).

Observa-se em ambas as figuras que os desvios padrão das forças médias, calculadas com base nas variáveis experimentais obtidas durante o exercício, são bem pequenos.

Dois são os fatores que poderiam contribuir diretamente para um aumento no desvio padrão das forças médias: o primeiro diz respeito às alterações antropométricas dos voluntários; o segundo trata da variação de velocidade angular durante o movimento de flexão e extensão (tabela 2). Ambos estes pontos serão melhor discutidos no próximo capitulo.

Tabela 2. Velocidade média executada pelos sujeitos durante os dez ciclos de exercício.

\begin{tabular}{ccc}
\cline { 2 - 3 } Sujeitos & \multicolumn{2}{c}{ Velocidade média $(\mathbf{\%} / \mathbf{s})$} \\
\hline 1 & Concêntrico & Excêntrico \\
2 & 100,2 & 109,3 \\
3 & 98,7 & 112,2 \\
4 & 97,5 & 107,3 \\
5 & 99,2 & 110,7 \\
média & 102,3 & 108,5 \\
\hline
\end{tabular}




\section{3 - Análise do sinal EMG do músculo reto femoral.}

4.3.1 - Relação entre a força muscular e padrão de ativação do músculo reto femoral.

A analise do sinal EMG obtido do músculo reto femoral durante o exercício com a resistência elástica foi dividida em duas etapas.

Nesta primeira etapa o objetivo da analise se resume em verificar se o sinal EMG apresenta um padrão correspondente ao da força gerada pelo músculo em função do tempo durante o exercício na flexão e extensão. Após o tratamento dos sinais conforme o item 3.6.2.2 do capítulo 3, obteve-se a curva de EMG apresentada na figura 48, cujo coeficiente de variabilidade é igual a 34,8\%.

As figuras 49 e 50 demonstram os sinais EMG referentes à contração concêntrica e excêntrica, já selecionados e prontos para serem submetidos ao teste de correlação de Spearman. O teste indicou que a correlação entre o sinal EMG e a força muscular durante a contração concêntrica é igual a 98\% e para a contração excêntrica igual a 97\% (figura 51 e 52). No entanto é importante deixar claro que esta correlação diz respeito somente ao padrão que as curvas adotam em função do tempo do ciclo.

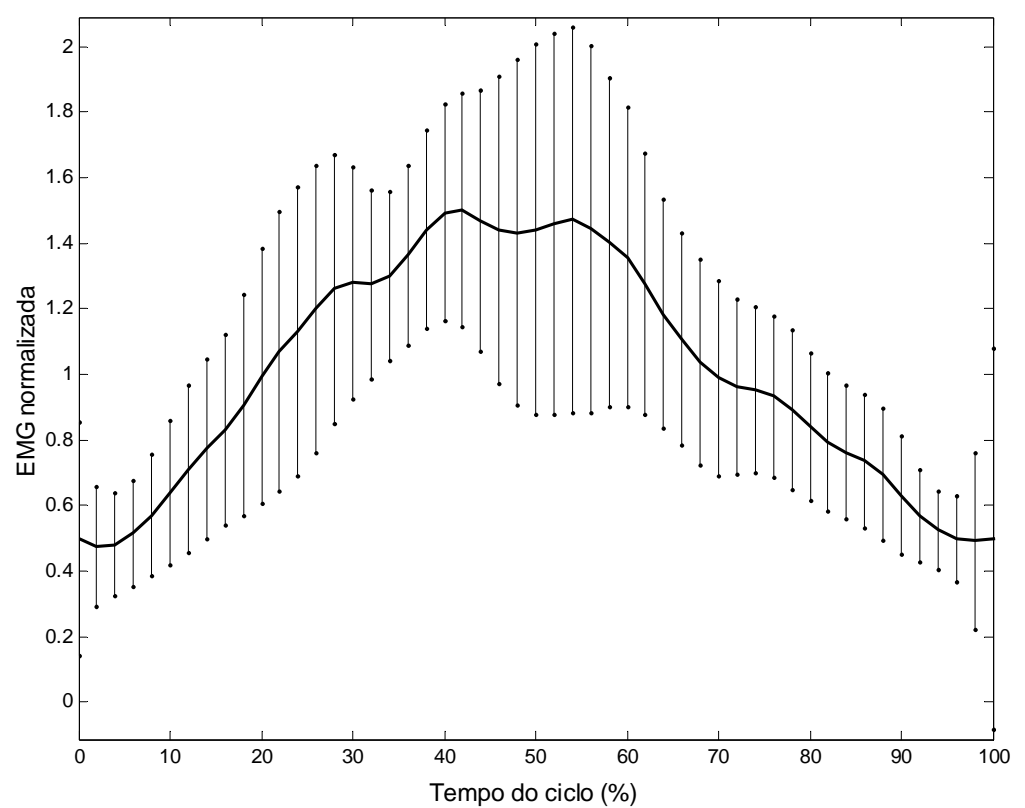

Figura 48. Sinal EMG do músculo reto femoral durante a execução do exercício com a resistência elástica para os cinco sujeitos $(\mathbf{n}=\mathbf{5 0})$. 


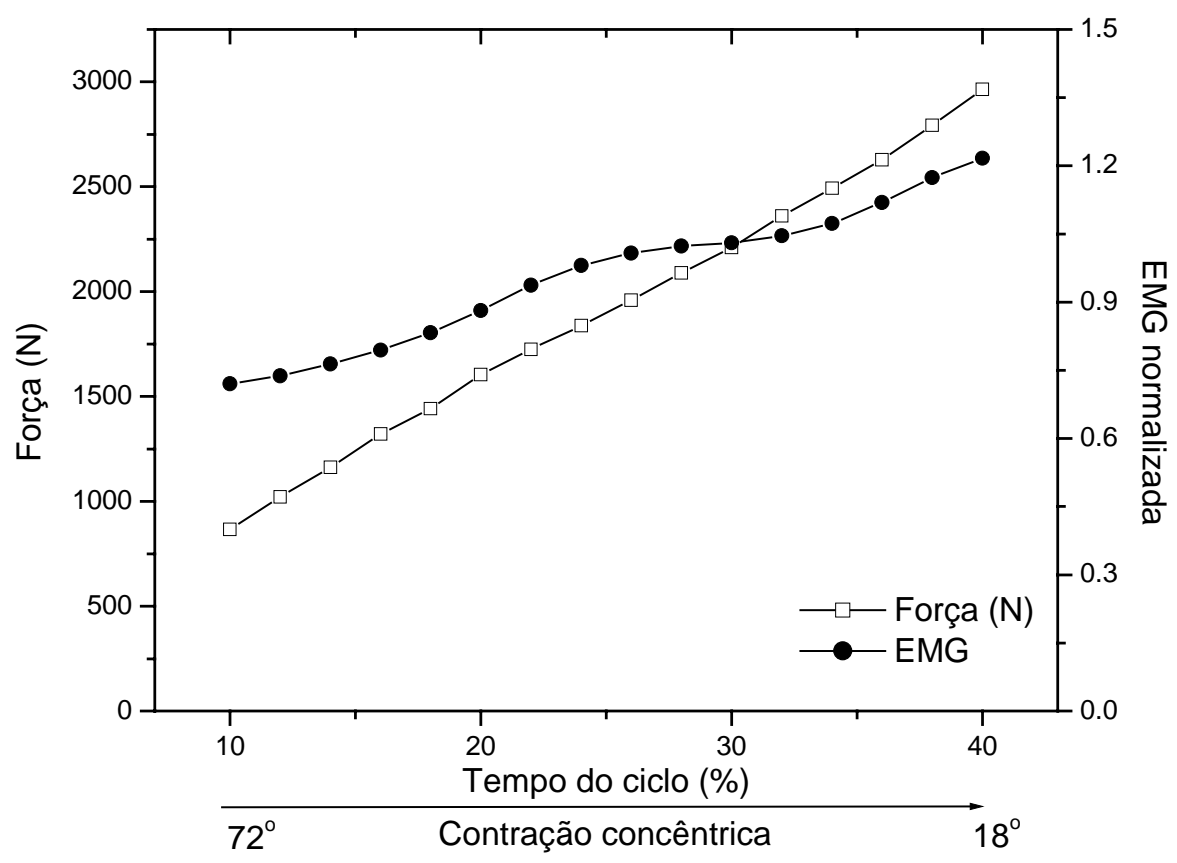

Figura 49. Sinal EMG e força do músculo reto femoral durante a execução da contração concêntrica no exercício com a resistência elástica.



Figura 50. Sinal EMG e força do músculo reto femoral durante a execução da contração concêntrica no exercício com a resistência elástica. 


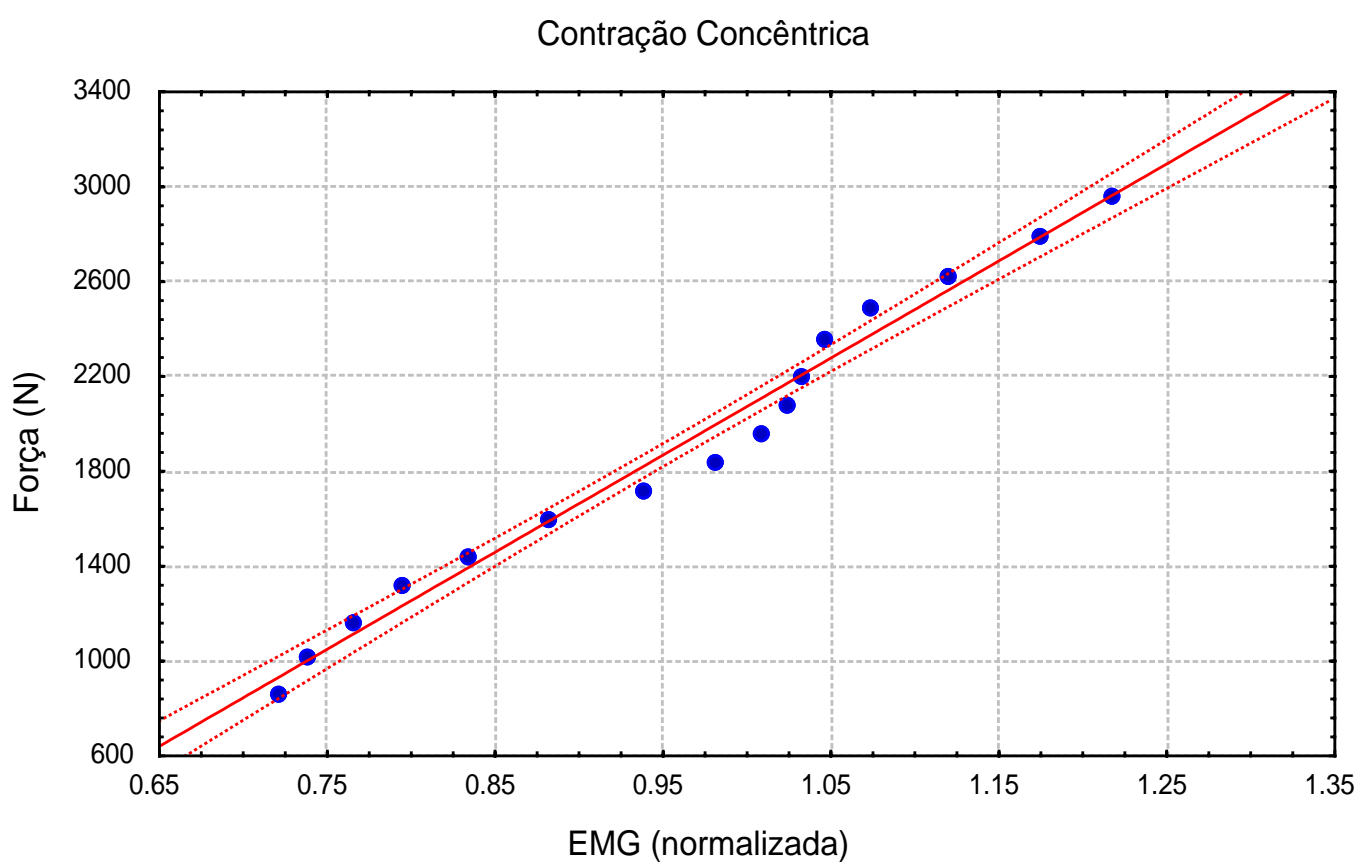

Figura 51. Teste de correlação entre o sinal EMG e a força durante a contração concêntrica no exercício com a resistência elástica. $O$ teste indica uma correlação entre os dados igual a $98 \%$.

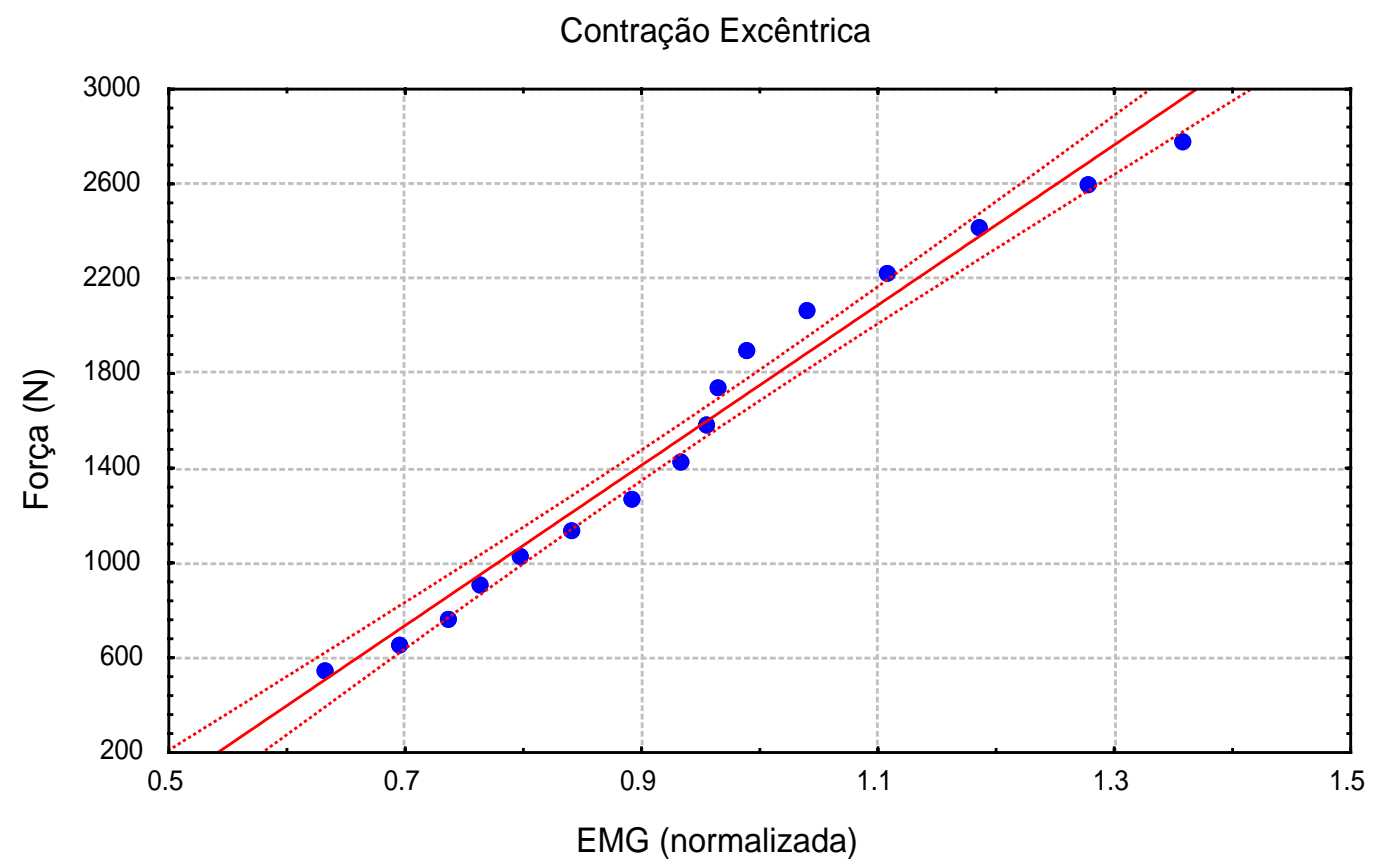

Figura 52. Teste de correlação entre o sinal EMG e a força durante a contração excêntrica no exercício com a resistência elástica. $O$ teste indica uma correlação entre os dados igual a $97 \%$. 
Os resultados apresentados nas figuras 51 e 52 demonstram que o padrão de ativação do músculo reto femoral é diretamente relacionado com a força gerada durante a contração concêntrica e excêntrica do músculo. Ou seja, o teste permite afirmar que existe uma correlação entre o crescimento e o decréscimo da força muscular e o correspondente crescimento ou decréscimo do sinal de EMG.

Com o objetivo de se melhorar a observação de correlações entre o sinal de EMG e a força concêntrica e excêntrica gerada pelo músculo durante o exercício, foi proposto o tratamento do sinal EMG conforme o item 3.6.2.2.

As figuras 53 e 54 apresentam o somatório acumulativo do sinal de EMG e a força para ambas as contrações ${ }^{1}$. Os valores do somatório acumulativo do sinal EMG e força foram aplicados ao teste de correlação de Spearman. O teste indicou que a correlação entre o somatório acumulativo do sinal EMG e a força muscular durante ambas as contrações é igual a 99\% (figura 55 e 56).

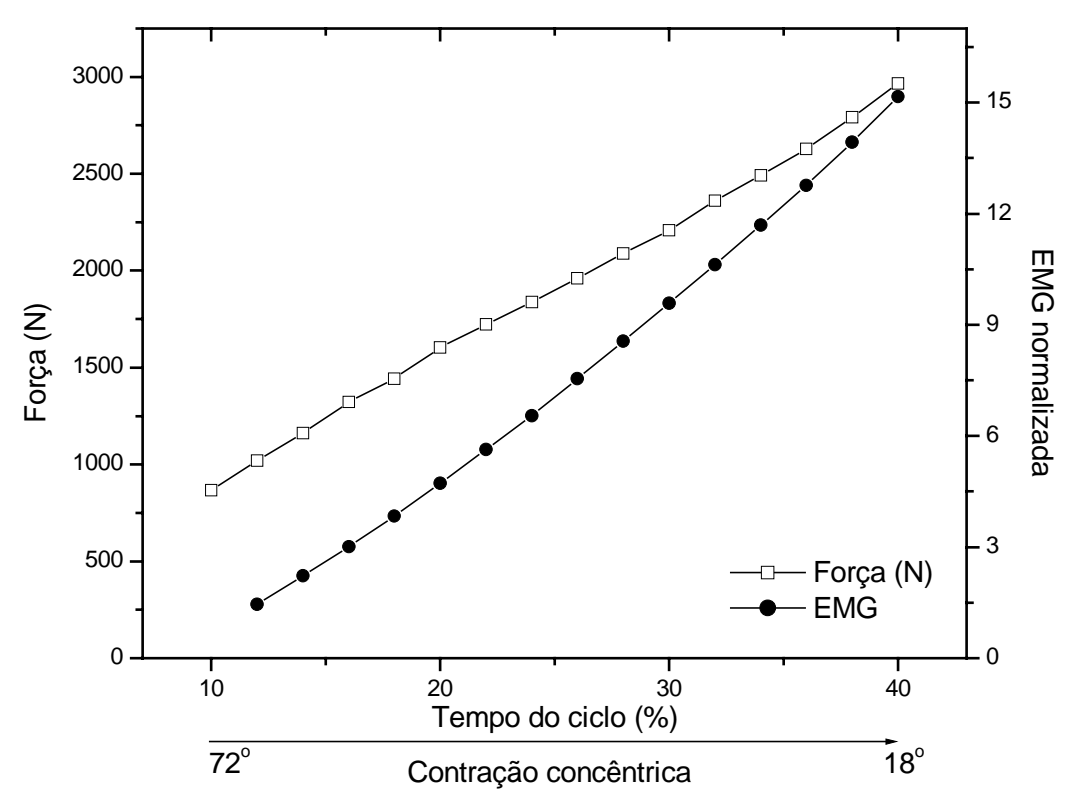

Figura 53. Somatório acumulativo do sinal EMG e força do músculo reto femoral durante a execução da contração concêntrica no exercício com a resistência elástica.

\footnotetext{
${ }^{1} \mathrm{Na}$ contração concêntrica soma-se as contribuições dos sinais EMG em todas as freqüências até atingir a contração máxima. Então, inicia-se a contração excêntrica, que neste caso o sinal da integral de cada ciclo é subtraído do valor inicial.
} 


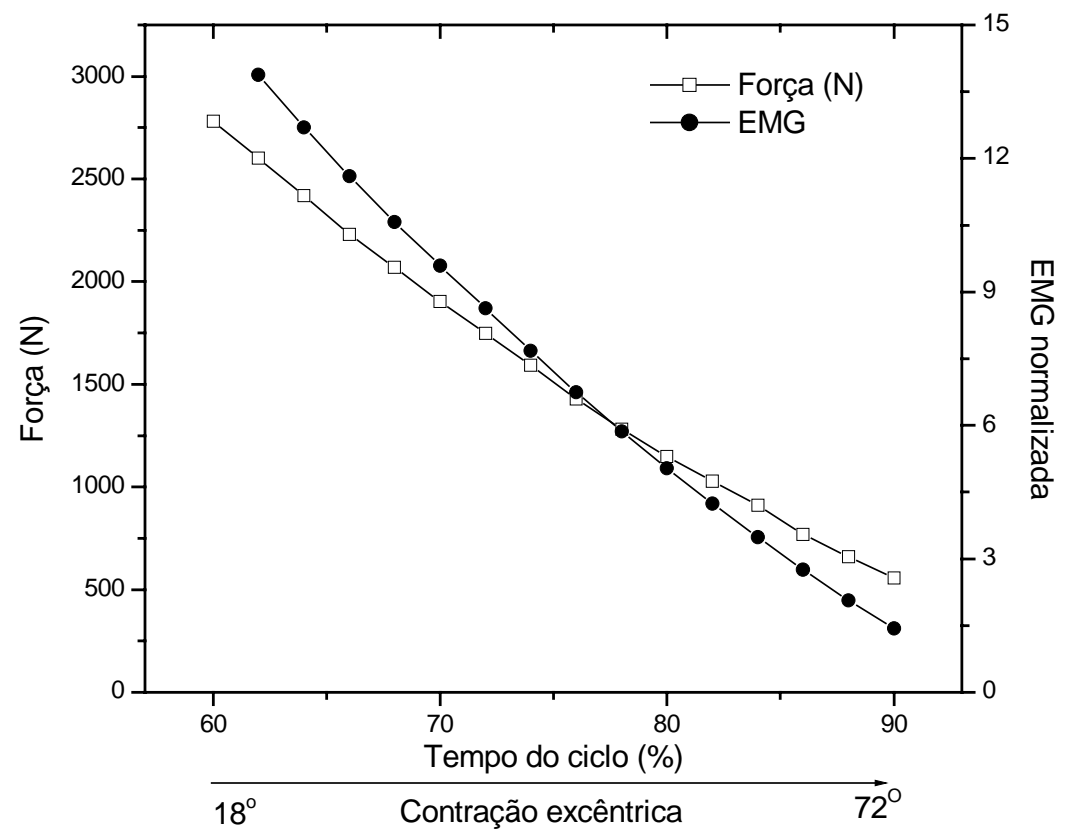

Figura 54. Somatório acumulativo do sinal EMG e força do músculo reto femoral durante a execução da contração concêntrica no exercício com a resistência elástica.

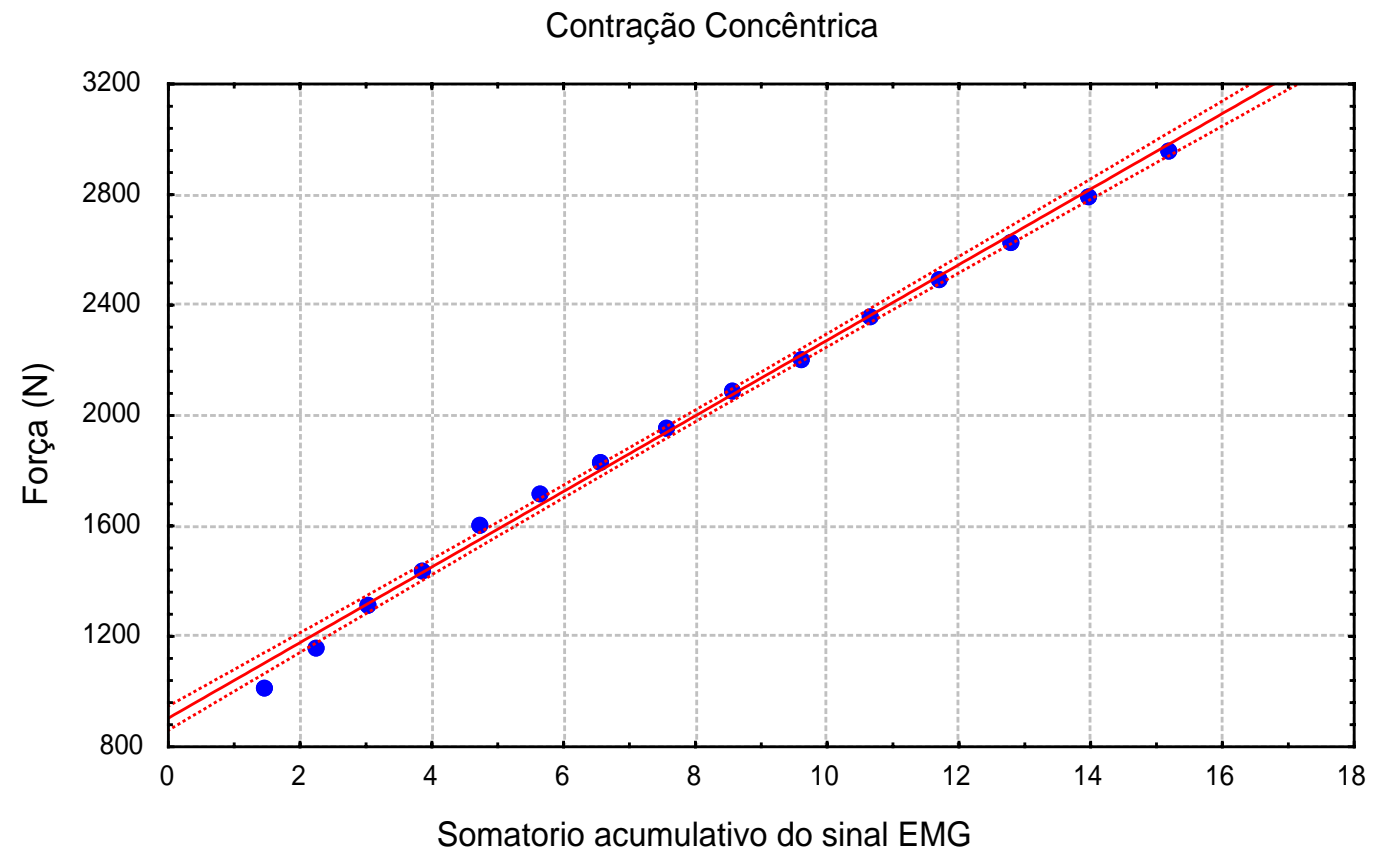

Figura 55. Teste de correlação entre o somatório acumulativo do sinal EMG e a força durante a contração concêntrica no exercício com a resistência elástica. $O$ teste indica uma correlação entre os dados igual a $99 \%$. 


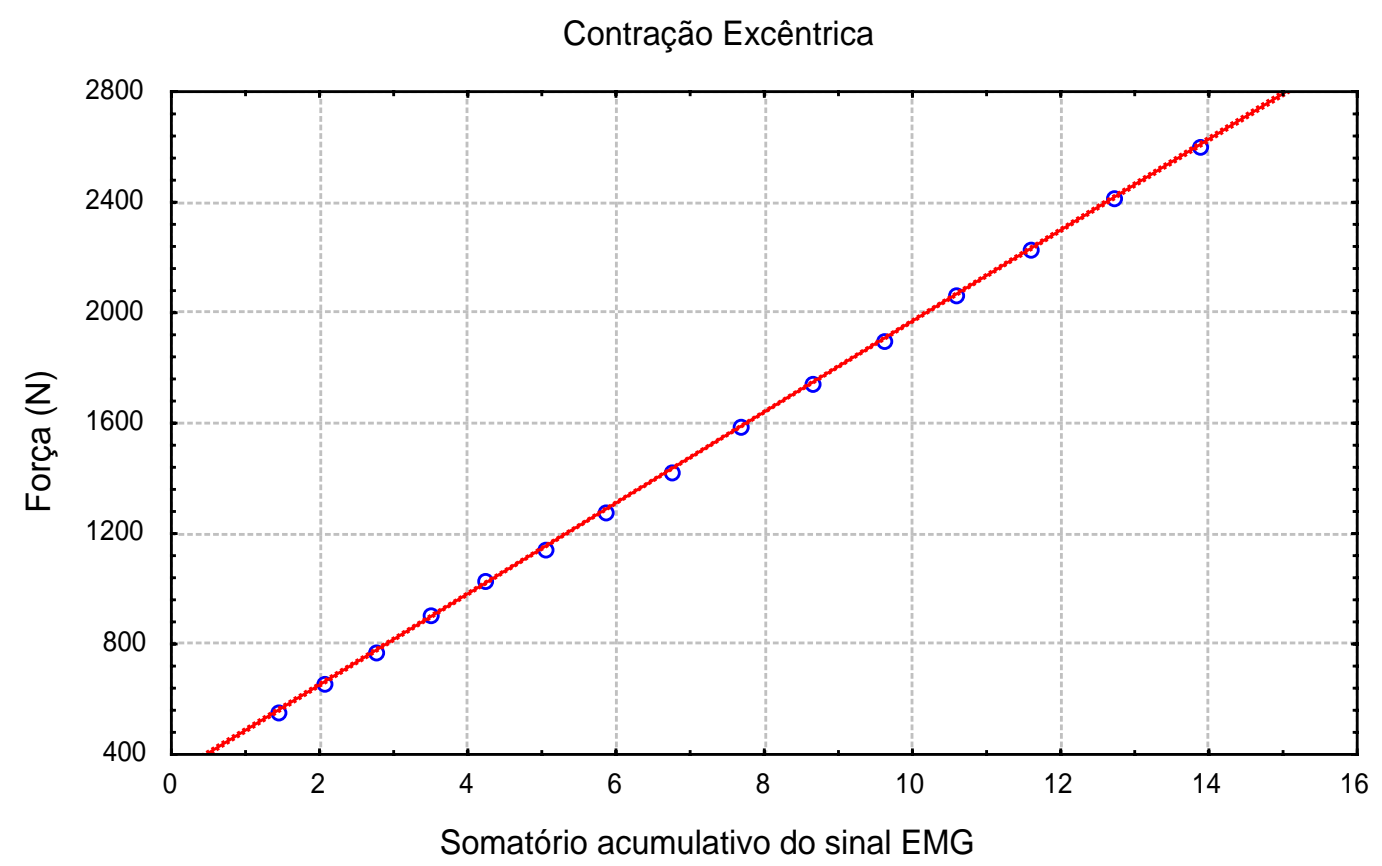

Figura 56. Teste de correlação entre o sinal EMG e a força durante a contração excêntrica no exercício com a resistência elástica. $O$ teste indica uma correlação entre os dados igual a $99 \%$.

\subsection{2 - O processo de fadiga muscular verificado através dos sinais EMG.}

Nesta segunda etapa do tratamento do sinal EMG do músculo reto femoral, objetivou-se identificar a existência de padrões no comportamento das variáveis espectrais quando o músculo é induzido a exaustão durante a realização do exercício com resistência elástica.

Após o tratamento dos sinais e a obtenção da freqüência mediana e média conforme os procedimentos descritos no item 3.6.2.1 do capítulo 3, obteve-se as curvas demonstradas nas figuras 57 e 58.

Observa-se em ambas as figuras que tanto a freqüência mediana quanto a média apresentam um declínio de padrão logarítmico das médias, em função do tempo em que os sujeitos realizam o exercício. O desvio padrão elevado em ambas as curvas pode ser interpretado como a diferença nos tempos de exercício que cada sujeito realizou (tabela 3). 
Frequencia mediana

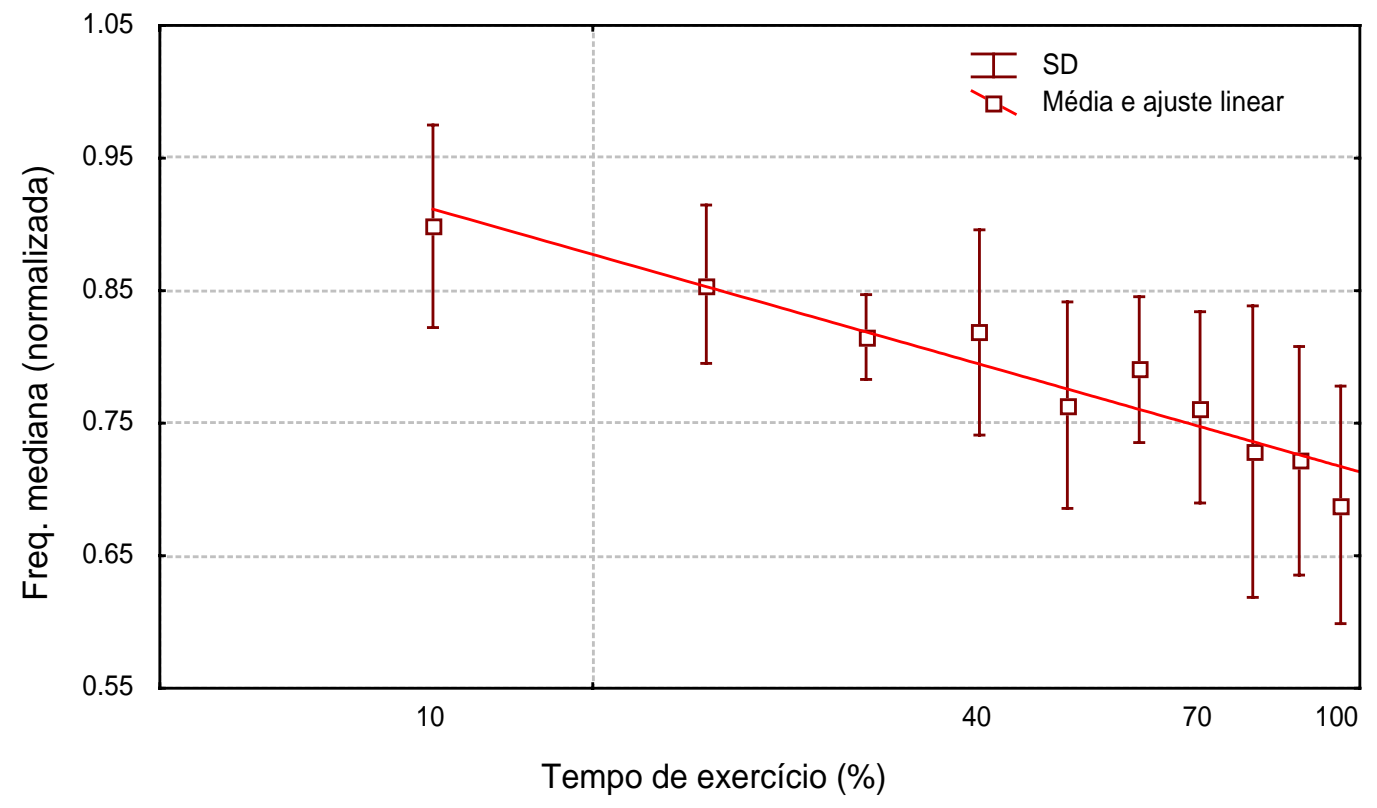

Figura 57. Comportamento da freqüência mediana durante o tempo total de exercício para os cinco sujeitos submetidos ao experimento.

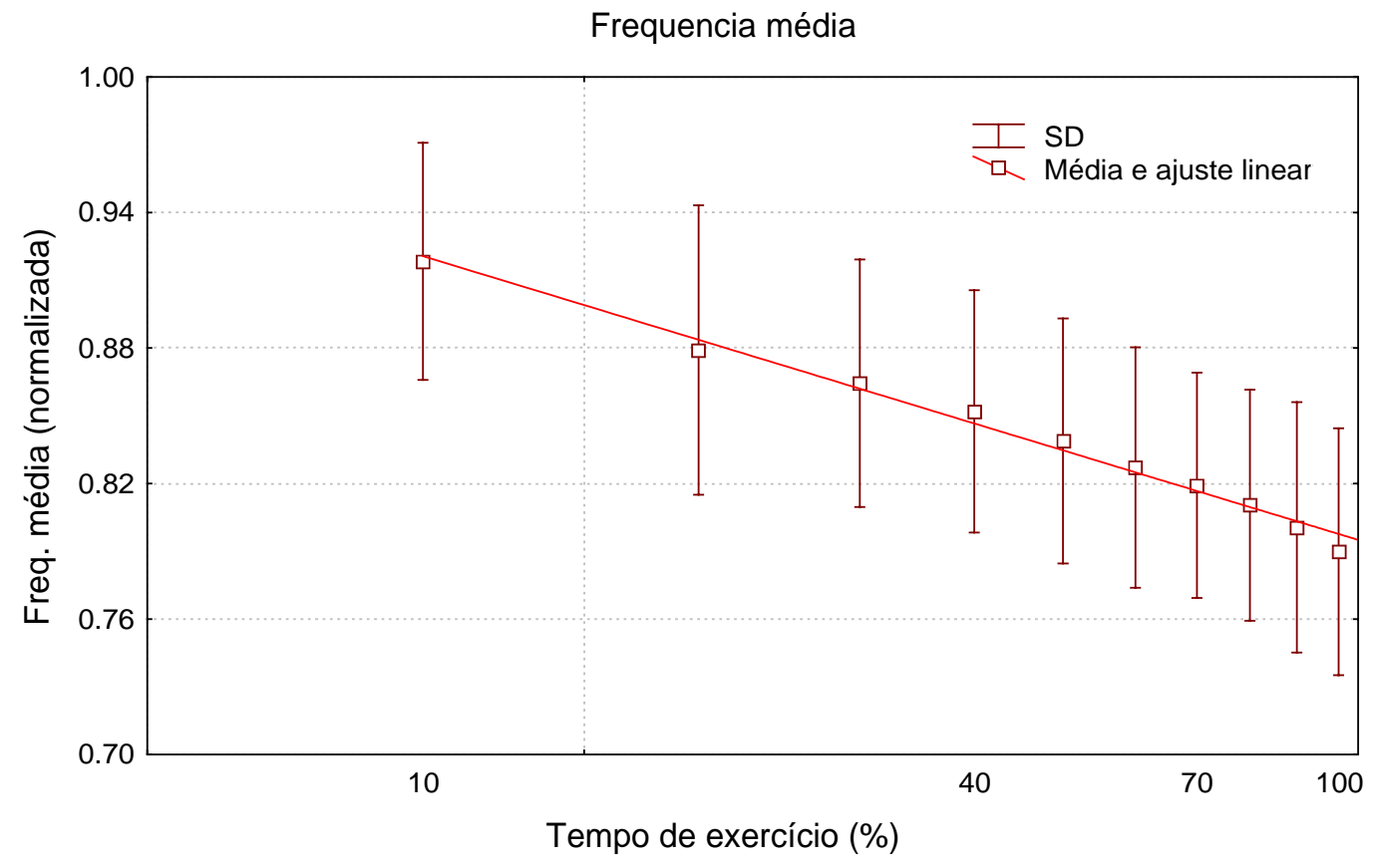

Figura 58. Comportamento da freqüência media durante o tempo total de exercício para os cinco sujeitos submetidos ao experimento. 
Tabela 3- Tempo de exercício realizado por cada voluntário.

\begin{tabular}{cc}
\hline Sujeitos & Tempo total de exercício (s) \\
\hline 1 & 105 \\
2 & 142 \\
3 & 380 \\
4 & 580 \\
5 & 262 \\
\hline
\end{tabular}


5-DISCUSSÃO 


\section{5- DISCUSSÃO}

Os resultados de força, apresentados no capítulo anterior, trazem informações interessantes a respeito do comportamento do músculo submetido ao exercício com resistência elástica.

Para a obtenção dos resultados de força foi utilizado um modelo biomecânico do joelho, baseado nas observações de Van Eidjin (1986). O modelo foi suficiente para tal propósito e os resultados de força provenientes da aplicação do mesmo são coerentes com a literatura que aborda o assunto (KAPANDJI, 2000; VAN EIDJIN, 1986; YAMAGUCHI \& ZAJAC, 1989).

As simulações abordaram três situações distintas que serviram para mostrar as relações entre os parâmetros dos tubos elásticos, como elasticidade e comprimento inicial, e o comportamento do músculo frente as alterações nestes parâmetros. A figura 44 demonstra claramente que um tubo que apresenta um fator de elasticidade muito grande ou um tubo que apresente comprimento inicial muito pequeno, vão inviabilizar a execução do exercício pelo paciente. Este fato indica a necessidade de mecanismos de avaliação específicos, para que a determinação da relação adequada entre a elasticidade e o comprimento inicial do tubo seja adequado para a aplicação em um paciente qualquer.

Neste sentido a simulação do exercício pode ser o passo inicial para a elaboração de uma ferramenta de avaliação que atenda esta necessidade, tendo em vista que nas clínicas de reabilitação, de uma forma geral, a prescrição de exercícios com resistência elástica é feita de forma precária. 
È importante ressaltar que esta precariedade está relacionada também com a forma como a resistência elástica é aplicada aos segmentos dos pacientes. Neste contexto se propôs o desenvolvimento de um sistema mecânico de exercício específico para a aplicação da resistência elástica.

Durante a fase experimental deste estudo, a aplicação da resistência elástica através do sistema de exercício se mostrou eficaz. Porém como foi observada a ausência de padronização da aplicação da resistência ao membro exercitado. Procurou projetar um sistema de exercício com o objetivo exclusivo de fazer com que a tensão gerada pelo tubo elástico fosse direcionada de forma perpendicular ao segmento durante todo o arco de movimento. No entanto observou-se que o sistema é uma ótima ferramenta para a padronização da aplicação da resistência, pois os pacientes devem se posicionar da mesma forma durante o exercício, fato que não ocorre no cotidiano clínico.

Esta padronização pode representar para o terapeuta a possibilidade de se avaliar e reavaliar a evolução do seu paciente de forma coerente. A possibilidade de se instrumentalizar o sistema de exercício, associado aos modelos biomecânicos já desenvolvidos para o mesmo, incluindo o apresentado neste estudo, possibilita ao terapeuta obter dados quantitativos que refletem diretamente a progressão do seu paciente de acordo com o protocolo de exercício prescrito (AZEVEDO et al., 2003).

O sistema de exercício desenvolvido não apresenta dispositivos limitadores de velocidade. Tal fato esta diretamente ligado ao questionamento, de que se o exercício com resistência elástica pode ser considerado como sendo isocinético ou não. Apesar do sistema de exercício desenvolvido não apresentar um dispositivo eletrônico de limitação de velocidade, o sistema de controle via feedback demonstrou ser suficiente para o propósito do estudo. Nas áreas de exercício selecionadas, da contração concêntrica e excêntrica, existiu uma variação da velocidade menor que $2^{\circ} / \mathrm{seg}$. Por este enfoque e levando-se em conta a definição de exercício isocinético proveniente da própria construção da palavra o exercício com resistência elástica da forma como foi proposto neste estudo pode sim, ser classificado como isocinetico. Assim como qualquer outro tipo de exercício que apresenta controle de velocidade durante a sua execução.

A diferença entre o sistema de exercício proposto e os dinamômetros isocinéticos comerciais, é que este ultimo apresenta uma característica biomecânica, derivada do mecanismo que o mesmo utiliza para o controle da velocidade do exercício. No dinamômetro isocinético a musculatura que esta sendo exercitada é induzida a produzir sua potencia máxima durante todo arco de movimento. Pode-se dizer que o 
principal atrativo dos sistemas isocinéticos é que o conjunto muscular exercitado trabalha exercendo a máxima potência possível com velocidade constante, ou seja, exerce a máxima potencia para a velocidade de exercício escolhida. Dessa forma em um dinamometro isocinético o indivíduo aplica a força máxima possível para cada velocidade de exercício escolhida. Por este motivo uma avaliação e um protocolo de exercício isocinético bem sucedidos não dependem apenas da maquina, mas também de um paciente colaborativo.

Outro diferencial entre os sistemas comerciais e o proposto neste estudo é a caracterização do comportamento mecânico do grupo muscular exercitado. Nos dispositivos comerciais os cálculos são feitos em função dos torques gerados pelo grupo muscular na alavanca exercitada não interessando a estes realizar medidas de forças internas geradas pelos músculos exercitados. No sistema desenvolvido implementou-se a avaliação de força interna através da aplicação de um modelo biomecânico que contempla as variações geométricas do músculo e da articulação, durante o arco de movimento do exercício.

Até que ponto a relação entre a força gerada e a velocidade de contração muscular proposta por Hill (1953) é valida, quando aplicada como base biomecânica que sustenta a concepção dos dinamômetros isocinéticos no que diz respeito a força e potencia muscular gerada durante o exercício? Observou-se neste estudo que ao se identificar a força interna do músculo leva-se em conta a variação do ângulo de inserção do mesmo durante o arco de movimento. E é esta variação que não torna válida a relação de Hill (1953) para a situação de exercício proposta neste estudo. Ou seja, a velocidade constante a que o segmento exercitado é mantido não garante que a velocidade de contração do músculo envolvido também seja constante.

Dessa forma, basta o fato de que a variação do ângulo de inserção do músculo acontece durante o movimento, não importando a modalidade de exercício, para que a relação de Hill (1953), também no caso do exercício isocinético, tenha suas limitações de aplicação.

Com relação ao padrão de geração de força durante o exercício com a resistência elástica, observa-se que a força apresenta um comportamento crescente durante a contração concêntrica e decrescente durante a contração excêntrica. Segundo as simulações, o padrão da força independe da configuração da corda aplicada, contudo a intensidade da força tem relação direta com estas configurações. 
Sabe-se que o músculo quadríceps é constituído, como o seu nome indica, por quatro corpos musculares que se inserem por um aparelho extensor na tuberosidade anterior da tíbia. Dentre estes quatro corpos musculares um chama mais a atenção pelas suas características mecânicas, o reto femoral. O interesse especial esta no fato de ser um músculo biarticular que tem a função tanto de flexor do quadril quanto extensor do joelho. Tal propriedade lhe confere uma importância superior, em relação aos outros músculos que compõe o quadríceps, dentro de atividades de vida diária como, por exemplo, o ato da marcha. Por este motivo o seu fortalecimento dentro de programas de reabilitação física é essencial.

Kapandji (2000) sugere que a ação de extensor do joelho do reto femoral dentro da dinâmica do quadríceps depende da posição do quadríceps. O autor afirma que quanto maior for à flexão do quadril menos otimizada estará a ação do reto femoral em estender o joelho, e que nesta posição o reto femoral seria incapaz de sozinho realizar a máxima extensão do joelho. No entanto as observações deste autor se resumem a situações onde o reto femoral se apresenta submetido à resistência ocasionada pela própria ação da gravidade na perna. Neste ponto é importante relembrar que os sujeitos deste estudo realizaram os exercícios sentados com o quadril posicionados em 90 graus.

Ao observar que, o padrão de ativação do músculo reto femoral de EMG obtido experimentalmente corresponde claramente ao comportamento físico do músculo quadríceps durante as duas contrações, figuras 51 e 52, pode-se sugerir que o músculo reto femoral é ativado durante todo o arco de movimento. Sugestão que não corresponde as afirmações de Kapandji (2000), mas que contempla uma nova situação a que este músculo foi submetido, a resistência elástica.

Nota-se também que não só o padrão de ativação do músculo reto femoral corresponde ao comportamento físico do músculo quadríceps, mas como também a proporção dos sinais EMG gerados durante as contrações, apresentam uma altíssima correlação com a força gerada pelo quadríceps (figuras 55 e 56). Tal resultado permite sugerir que o músculo reto femoral não só trabalha durante todo o arco de movimento do exercício como também aparentemente é o se principal executor.

É importante deixar claro que a proporção do sinal EMG gerado durante a contração foi obtido através da obtenção do somatório acumulativo do sinal ou como alguns autores se referem, a integral do sinal (MORITANI, 1978; LIPPOLD \& EDWARDS, 1956; LIPPOLD, 1952). Tal ferramenta de análise necessita de uma 
discussão mais aprofundada com relação a abrangência de sua aplicação. Cabe lembrar que as sugestões apresentadas anteriormente, baseadas nos resultados proporcionados por este método de análise se basearam em uma única situação experimental de exercício.

Contudo o recrutamento das fibras e o padrão de despolarização das mesmas sofrem alterações em função do tempo do exercício a medida que este entra em estado de fadiga. No intuito de se observar tais alterações, propôs-se neste estudo a analise do sinal EMG no domínio da freqüência.

As observações das alterações nos parâmetros espectrais (PE) do sinal EMG são bastante utilizadas no sentido de se monitorar o processo de fadiga muscular (LINDSTRON, 1970). A proposta de identificação de um padrão na alteração dos parâmetros espectrais, Fmed e FM, pode representar um primeiro passo no sentido de se desenvolver uma ferramenta de avaliação. Tal ferramenta empregada de forma integrada ao sistema de exercício teria como objetivo evitar que o sujeito trabalhe além dos limites adequados de fadiga.

Os resultados apresentados neste estudo (figuras 57 e 58) sugerem a existência de um padrão de decréscimo logaritimico de ambos os parâmetros espectrais em função do tempo de exercício. Lowery et al. (2002) também demonstrou um padrão de decréscimo linear de Fmed e FM em exercícios isométricos do músculo braquiorradial, a três intensidades diferentes. Azevedo et al. (2003a e b) sugere que o padrão de decréscimo dos PE independe da intensidade de força que é gerada pelo músculo, no entanto a inclinação da reta que descreve este parâmetro se altera de forma diretamente proporcional a intensidade de força gerada.

Vários autores se referem a relação entre a compressão do espectro de freqüência do sinal EMG e o processo de fadiga muscular, no entanto tais relações são bem estabelecidas em sinais provenientes de contrações isométricas (DeLUCA, 1997, YAAR, 1989; LINDSTRON, 1970). Neste ponto deve-se lembrar que os resultados apresentados neste estudo são provenientes de contrações dinâmicas. A metodologia que envolve o tratamento de tais sinais ainda não esta bem determinada, fato que impede uma discussão mais aprofundada a respeito da metodologia empregada neste estudo. 
Portanto, verifica-se que o futuro desenvolvimento de uma ferramenta que possa ser empregada no monitoramento do processo de fadiga muscular em exercícios dinâmicos é viável. Ferramenta esta que pode complementar e auxiliar nos processos de avaliação quantitativos que poderão futuramente envolver não só a aplicação da resistência elástica, mas qualquer outro tipo de exercício dinâmico. 
6- CONCLUSÃO 


\section{6- CONCLUSÃO}

Buscando avaliar o exercício com a resistência elástica sob aspecto da teoria isocinética, conclui-se que a principal diferença em relação aos sistemas isocineticos comerciais é que o sistema de exercício desenvolvido neste estudo não garante a aplicação da potencia máxima muscular para a velocidade escolhida. Mas como ganho complementar o modelo biomecânico possibilita a avaliação da força interna gerada pelo músculo quadríceps durante o exercício, fato que permite um olhar diferente daquele que é possível nos sistemas isocinéticos comerciais.

O sistema mecânico de exercício desenvolvido para aplicação da resistência elástica permitiu a padronização e o controle da velocidade de exercício através do mecanismo de biofeedback. Esta ultima característica permite a classificação do exercício proposto neste estudo como isocinético.

A análise dos sinais EMG no domínio do tempo associada aos valores de força muscular sugere que a resistência elástica interage com a mecânica muscular de forma específica. Não podendo dessa forma ser utilizado, na clinica, de maneira generalista e sem que critérios de avaliação específicos para a sua aplicação sejam desenvolvidos.

A observação do comportamento dos parâmetros espectrais dos sinais EMG demonstraram que uma relação logarítmica entre os seus declínios e o tempo de exercício acontece. Tal relação estudada e discutida em profundidade pode servir de base para o desenvolvimento de uma ferramenta de avaliação do processo de fadiga muscular, que pode ser integrada ao sistema de exercício proposto neste estudo como ser utilizada isoladamente em outros tipos de exercício dinâmicos. 
7- REFERÊNCIAS BIBLIOGRÁFICAS 


\section{7- REFERÊNCIAS BIBLIOGRÁFICAS.}

ALMEIDA, M. A. F. Filtragem Digital de Sinais Biomédicos. 116 p. Tese de Mestrado, PGEEL, UFSC, Florianópolis, Brasil. 1997.

AMADIO, A. C. Fundamentos biomecânicos para a análise do movimento humano. São Paulo, Laboratório de Biomecânica / EEFUSP, 1996. 162p.

AMADIO, A. C.; BARBANTI, V. J (orgs.). A biodinâmica do movimento humano e suas relações interdisciplinares. São Paulo, Estação liberdade, 2000, 262p.

AZEVEDO, F. M.; ALVES, N.; NEGRÃO FILHO, R. F, TELLO, C.F.; BENATTI, L.N. Avaliação biomecânica do músculo bíceps braquial submetido a um programa de de fortalecimento através de um sistema mecânico de exercício baseado em resistência elástica. In: X Congresso Brasileiro de Biomecânica, Ouro Preto, 2003.

AZEVEDO, F. M.; ALVES, N.; NEGRÃO FILHO, R. F. Desenvolvimento de um sistema de tração baseado em resistência elástica para a realização de exercícios dinâmicos em membros superiores. In: XVIII CONGRESSO BRASILEIRO DE ENGENHARIA BIOMÉDICA, São José dos Campos, 2002. p.277-282.

AZEVEdo, F. M., AlveS, N., CARVAlHO, A. C., NEGRÃO FILHO, R. F. Avaliação da atividade elétrica do músculo bíceps braquial durante o exercício com uma resistência elástica, comparado ao exercício com uma resistência fixa. In: CONGRESSO LATINO-AMERICANO DE ENGENHARIA BIOMÉDICA, Havana Cuba, 2001. p.190-197.

AZEVEDO, F. M.; ALVES, N.; CARVALHO, A. C. Avaliação do torque e da força gerada pelo músculo bíceps braquial durante o exercício com uma resistência elástica, comparados aos exercícios com uma resistência fixa e ao isocinético. In: XVII CONGRESSO BRASILEIRO DE ENGENHARIA BIOMÉDICA, Florianópolis, 2000. p.167-172. 
AZEVEDO, F. M.; NEGRÃO FILHO R. F.; CARVALHO A. C. A atividade elétrica do músculo bíceps braquial em diferentes ângulos e resistências. Revista de fisioterapia da Universidade de São Paulo, v. 6, suplemento, p. 36, 1999a.

AZEVEDO F.M. Estudo do torque e da força gerada pelo músculo bíceps braquail submetido a exercícios com resistência elástica. Relatório final de iniciação científica apresentado a Fundação de Amparo a Pesquisa do Estado de São Paulo. Processo número 98/16088-2. 1999b

AZEVEDO, F. M.; VAlENTE, C. A. P.; ONIZUKA, A. C; CARVAlHO, A. C. Estudo da resistência do tubo de látex submetido a estiramentos. In: X CONGRESSO DE INICIAÇÃO CIENTIFICA DA UNESP, Araraquara, 1998. p. 295.

BARBANTI, V.J. Teoria e prática do treinamento desportivo. São Paulo: Manole, 1992. 708p.

BARBANTI, V.J. Treinamento físico - Bases científicas. São Paulo: CLR Baleiro, 1986. 107p.

BAUMANN, W. Procedimentos para determinar as forças internas na biomecânica do ser humano - aspectos da carga e sobrecarga nas extremidades inferiores. In: IV CONGRESSO BRASILEIRO DE BIOMECÂNICA. Brasília, 1995, não paginado.

BIGLAND-RICHIE, B. Excitation frequency and muscle fatigue electrical responses during human voluntary and stimated contractions. Exp. Neurol. v.64, p.414-427, 1979.

BROMAN, H.; BILOTTO, G.; DE LUCA, C.J. Myoelectric signal conduction velocity and spectral parameters: influence of forçe and time. Journal of Applied Physiology. v.58. p.1428-1437, 1985.

BROWN, M.S.H.; STEIN, B.R. The relation between the surface electromyogram and muscular force. Journal of Physiology. _, 549-569. 1974.

CESARELLI, M.; BIFULCO, P.; BRACALE, M. Quadriceps muscles activation in anterior knee pain during isokinetic exercise. Medical Engineering \& Physics. 21 (1999) 469-478.

FARINA, D. MERLETTI, R.; RAINOLDI, A.; BUINOCORE, M. Two methods for the measurement of voluntary contraction torque in the biceps brachii muscle. Medical Engineering \& Physics. 21 (1999) 533-540.

DE LUCA, C. Physiology and Mathematics of Myoelectric Signals. IEEE Transactions on Biomedical Engineering, v. BME-26, n.6, p.313-325, 1979.

DE LUCA, C.J. The use of surface electromyografic in biomechanics. Journal of Applied Biomechanics, v. 13, p.135-63, 1997.

DE LUCA, C.J.; BASMAJIAN, J. Muscles alive: Their functions revealed by eletromyography. 5.ed. USA, 1985. 561p. 
DELSYS INC. A Discussion on Surface Electromyography: Detection And Recording,[on line]. Disponível: http://www.delsys.com/emg_articles/EMG.shtml [acesso em: 11/03/2002].

DVIR, Z. Isocinética: Avaliações Musculares, Interpretações e Aplicações Clínicas. São Paulo: Manole, 2002. 201p.

FESS, E.E.; PHILLIPS, C.A. Hand Splinting Principles and Methods. St. Louis, Mo: CV Mosby Co, p.163-187, 1987.

GEDES, L. A. Electrodes and the Measurement of Bioelectric Events. New York: Wiley, 1972.

GLITCH, U.; BAUMANN, W. The three - dimensional determination of internal loads in the lower extremity. Journal of biomechanics. V. 30, N.11, pp. $1123-1131,1997$.

GRENBLATT, D.; DIESEL, W.; NOAKES, T.D. Clinical assessment of the low-cost VariCom isokinetic knee exerciser. Med. Eng. Phys. 19, 273-278. 1997.

HERTING, D.; KESSLER, R.M. The shoulder and shoulder girdle. In: Management of common Musculoskeletal Disorders: Physical Therapy Principles and Methods. 3rd. ed. Philadelphia, Pa: Lippincott, 1996. 186p.

HILL, A. V. The Mechanics of active muscle. Proceedings of the Royal Society 141B: pp. $104-117,1953$.

HINTERMEISTER R. A. Electromyographic activity and applied load during shouder rehabilitation exercises using elastic resistance. The American journal of sports medicine. v. 26, N. 2, pp. 210 - 220, 1998a.

HINTERMEISTER R. A. Quantification of elastic resistance knee rehabilitation exercises. Journal of orthopeadic \& sports physical therapy. V. 28, N. 1, pp. 40 -50, $1998 b$.

HISLOP, H., \& PERRINE, J.J. The isokinetic concept of exercise. Phisical Therapy, v.47, p.114-117, 1967.

HOLlmanN, W.; HeTtingER, T. Medicina do esporte. São Paulo: Manole, 1989. $678 \mathrm{p}$.

HUGHES, C.J.; HURD, K.; JONES, A;SPRINGLE, S. Resistence properties of TheraBand tubing during shouder abduction exercise. J. Orthop Sports Phys Ther., [S.L.], v.29, p.413-20, 1999.

KAPANDJI, I.A.. Fisiologia articular. 3, São Paulo, Panamericana, 2000.

KISNER, C.; COLBY, L. A. Exercícios terapêuticos. 3.ed. São Paulo: Manole, 1998. $746 p$. 
KOMI, P.V. et. al. EMG frequency spectrum, muscle structure, and fatigue during dynamic contractions in man. European Physiologic Medical Reabilitation. v.42, n.1, p. 41-50, 1979.

KOTTKE, F.J., LEHMANN, J.F. Tratado de medicina física e reabilitação de Krusen. 4.ed. São Paulo: Manole, 1994. 707p.

KRNJEVIC, K., MILEDI, R. Failure of Neuromuscular Propagation in Rats, Journal of. Physiology. London, 140, 440-461. 1958.

LAWRENCE, J.H.; DE LUCA, C.J. Myoelectric signal versus force relationship in different human muscles. Journal of Applied .Physiology. 54(6), 1653 - 1659. 1983.

LEVA, P. Adjustments to zatsiorsky-seluyanov's segment inertia parameters. Journal of Biomechanics. v. 29, n. 9, p. 1223-1230, 1996.

LIPPOLD, O.C.J.; EDWARDS, R.G. The relaction between force and integrated electrical activity in fatigued muscle. Journal of Physiology. v. 132, p. 668-677, 1956.

LIPPOLD,O.C.J. The relation between integrated action potentials in a human muscle and its isometric tension. Journal of Physiology. v.7, p. 492-499, 1952.

LUH, J.J.; CHANGA, G.C.;CHENG, C.K.; LAI, J.S. Isokinetic elbow joint torques estimation from surface EMG and joint kinematic data: using an artificial neural network model. Journal of Electromyography and Kinesiology. 9, 173-183, 1999.

LINDSTRON, L. An electromyographic index for localized muscle fatigue. Journal of Applied Physiology. v.43, n.4, p.750-54, 1977.

LINDSTRÖN, L.; KADEFORS, R.; PETERSEN, I. Muscular fatigue and action potential conduction velocity changes studies with frequency analysis of EMG signals. Electromyography. v.10, p.341-356, 1970

MOHAMED, O.; PERRY, J.; HISLOP, H. Relationship between wire EMG activity, muscle length and torque of the hamstrings. Clinical Biomechanics. 17, 569-579. 2002.

MORITANI, T.; NAGATA, A.; MURO,M. Electromyographic manifestations of muscular fatigue. Méd. Sci. Sports Exercises. v.14, p.198-202, 1982.

MORITANI, T.; HERBERT, A. Reexamination of the relationship between the sufarce integrated electromyogram (IEMG) and forçe of isometric contraction. American Journal of Physical Medicine. 57:6, 263-277. 1978.

ONISHI, H.; YAGI, R.; MOMOSE, K.; IHASHI, K.; HANDA, Y. Relationship between EMG signals and force in human vastus lateralis muscle using multiple bipolar wire electrodes. Journal of Electromyography and Kinesiology. 10, 59-67. 1999.

PATON, W. D. M.; WAUD, D. R. The Margin of Safety of Neuromuscular Transmition, Journal of Physiology., London, 191, 59-60. 1967. 
PATTERSON, M. et al. Material Proerties of Thera-Band Tubing Phisical Thrapy. Vol 81, pp. 1438 - 1444, 2001.

PEREIRA, M.C.V.; AZEVEDO, F.M. Análise para um ajanelamento adequado para sinais bioelétricos. In: XVIII CONGRESSO BRASILEIRO DE ENGENHARIA BIOMÉDICA, São José dos Campos, 2002. Cd-rom.

PERRINE, J. J.; EDGERTON, V. R. Muscle force-velocyty and power-veloci relationships under isokinetic loading. Medicine and Science in Sports and Exercise. 10: 159-166, 1978.

PERRIN, D. H. Isokinetic exercise and assessment. U.S.A: Humam Publishers, 1993. $211 \mathrm{p}$.

POWERS, S. K., HOWLEY, E. T. Fisiologia do exercício. 3.ed. São Paulo: Manole, 2000.527p.

PRIMAL PICTURES. Anatomic pictures [on line]. Disponível: http://www.primalpictures.com [acesso em: 11/03/2002].

SIMONEAU, G. G. et al. Biomechanics of elastic resistence in therapeutic exercise programs. Journal of orthopeadic \& sports physical therapy. V. 1, N.31, pp. 16-24, 2001.

STULEN, F.B.; DE LUCA, C.J. Frequncy parameters of the myoeletric signal as a measure of muscle conduction velocity. IEEE Transactions on Biomedical Engineering. New YorK, 7, 515-523. 1981.

TUBINO, M.J.G. Metodologia científica do treinamento desportivo. São Paulo: Ibrasa, 1979. 435p.

VAN EIJDEN, T. M. G. J; et al. A mathematical model of the patellofemoral joint. Journal of biomechanics. Vol. 19, N. 3, pp. 219 - 229, 1986.

VECCHIA, C.M. Aspectos metodológicos para a determinação de cargas internas no segmento inferior humano. Istituto de Física da Universidade de São Paulo. 1998.

VLACK, L. H. V. Principios da ciência dos materiais. São Paulo: Edgard Blücher, 1970. 472p.

WEBSTER, J. G., Medical Instrumentation: Application and Design. Editor: Jonh G. Webster, 3.ed., New York, 1998.

WEINECK, J. Biologia do esporte. São Paulo: Manole, 1991. 599p.

WINTER, D. A. The biomechanics and motor control of human movement. 2.ed. John Wiley \& Sons, 1990.

YAAR, N. Influence pattern power spectrum analysis in neuro-muscular disorders. Eletromyography Clinical Neurophysiology. 29, 473 - 484. 1989. 
YAMACHUCHI, G. T.; ZAJAC, F. E. A planar model of the knee joint to characterize the knee extensor mechanism. Journal of biomechanics. 22 (1), 1-10. 1998.

YUNG-HUI, L.; LEE, T. H. Muscle response while holding an unstable load. Clinical Biomechanics. 17 (2002) 250-256.

ZATIORSKY, V.M. et al. Biomechanik des menschichen bewgungspparates. Berlim: Sportverlag, 1984.

ZATIORSKY, V.M; SELUYANOV, V.N; The mass and inertia characteristics of the main segments of the human body. In: H.MATSUI E KOBAYASHI Biomechanics VIII-B. Champaing Illinois: Human Kinectics Publishers. 1983. 